\title{
QUANTIFICAÇÃO DA DEFORMAÇÃO EM MIGMATITOS METATEXITOS ESTROMÁTICOS E ROCHAS ASSOCIADAS DO COMPLEXO ATUBA, PORÇÃO LESTE DO ESTADO DO PARANÁ
}

\author{
QUANTIFICATION OF DEFORMATION IN STROMATIC METATHEXITE MIGMATITES \\ AND ASSOCIATED ROCKS OF THE ATUBA COMPLEX, EASTERN PARANÁ STATE
}

\author{
Introdução \\ Geologia regional \\ Materiais e métodos \\ Resultados \\ Discussões \\ Conclusões \\ Referências
}

Michelangelo Tissi BALDIN, Eduardo SALAMUNI, Leonardo Evangelista LAGOEIRO

UFPR - Universidade Federal do Paraná. Departamento de Geologia. Av. Coronel Francisco Heráclito Dos Santos, Jardim das Américas, 210. Curitiba - PR. E-mails: michelangelotissibaldin@gmail.com; salamuni@ufpr.br; leonardo.lagoeiro@ufpr.br

\begin{abstract}
RESUMO - O Complexo Atuba aflora na porção leste do Estado do Paraná, segundo uma faixa alongada de direção NE-SW e compreende a parte sul do Cinturão Ribeira. Este trabalho tem como objetivo principal elucidar os processos deformacionais do Complexo Atuba. A investigação foi desenvolvida por meio de investigação de campo, petrografia e análise estrutural quantitativa e, complementa vários estudos tectônicos já realizados anteriormente. Os migmatitos metatexitos estromáticos possuem médio a alto grau metamórfico e são compostos por neossomas residuais tonalíticos intercalados com leucossomas graníticos ou granodioríticostonalíticos e melanossomas máficos. Muitas vezes podem ser classificados como pertencentes à série dos milonitos. Observam-se também anfibolitos, xistos, gnaisses granulíticos, diatexitos schollen, quartzitos e granitoides. Dois planos de foliação, ambos gerados por cisalhamento dúctil, foram identificados: o primeiro é caracterizado pela foliação Sn-1 associada à tectônica de cavalgamento (Dn1) e o segundo pela foliação Sn produzido por tectônica transpressiva sinistral (Dn). Os resultados confirmam que a última fase foi acomodada pela partição da deformação. A quantificação da deformação foi desenvolvida por intermédio dos métodos de Fry, Polar e $\mathrm{Rf} / \varphi$, com base na análise de cristais de quartzo e feldspatos em 26 lâminas delgadas. As amostras revelaram razões de deformação similares para todos os métodos utilizados nos planos XZ e YZ. Os elipsoides possuem forma oblata e correspondem ao campo do achatamento aparente.
\end{abstract}

Palavras-chave: Análise estrutural. Migmatitos. Transpressão.

\begin{abstract}
The Atuba Complex emerges in the eastern portion of the State of Paraná, along an NE-SW elongated swath and comprises the southern part of the Ribeira Belt. This work has as main objective to define the tectonic and deformational regimes of the Atuba Complex. The research was developed through field research, petrography and quantitative structural analysis and complements several tectonic studies already performed. Stromatic metathexite migmatites have medium to high metamorphic grade and are composed of tonalitic residual neosomes interspersed with granitic or tonalitic-granodioritic leukosomes and mafic melanosomes. They can often be classified as belonging to the series of milonites. Amphibolites, schists, granulitic gneisses, schollen diatexites, quartzites and granitoids are also observed. Two foliation planes, both generated by ductile shear, were identified: the first is characterized by Sn-1 foliation associated with thrusting tectonics (Dn-1) and the second by Sn foliation produced by sinistral transpressive tectonics (Dn). The results confirm that the last phase was accommodated by the deformation partition. The quantification of deformation was developed using the Fry, Polar and Rf/ $\varphi$ method, based on analysis of quartz and feldspar crystals on 26 thin section. Samples revealed similar strain ratios for all methods used in the XZ and YZ planes. The ellipsoids are oblate in shape and correspond to the apparent flattening field.
\end{abstract}

Keywords: Structural analysis. Migmatites. Transpression.

\section{INTRODUÇÃO}

A evolução crustal na porção sul do Brasil abrangeu eventos tectônicos que levaram à amalgamação de diversos terrenos durante a orogenia colisional neoproterozoica, resultando na formação do Gondwana Ocidental até o início do Cambriano (Campos Neto, 2000; Basei et al., 2008). Os terrenos metamórficos de alto grau ocupam grande parte do território brasileiro e ocorrem ao longo de faixas móveis na região costeira, bem como nas bordas e no interior de crátons, formando uma extensa área da crosta continental. O estudo da evolução desses terrenos é complexo, considerando-se os diversos processos deformacionais que atuaram ao longo do tempo geológico, havendo lacunas que necessitam ser explanadas (Melo \& Oliveira, 2013).

A Província Mantiqueira estende-se na direção NNE-SSW por aproximadamente 3.000 km e ocorre na porção sudeste e sul do Brasil. É composta pelos cinturões Araçuaí, Ribeira e Dom Feliciano (Almeida et al., 1981; Heilbron et al., 2004). O Cinturão Ribeira ocupa a porção 
sudeste da Província Mantiqueira, aparece limitado por zonas de cisalhamento transpressivas ou de cavalgamento e ocorre como um complexo orógeno colisional, com tendência NE, que foi amalgamado, deformado e metamorfizado durante a Orogenia Brasiliano-Pan Africana (Campanha \& Brito Neves, 2004; Heilbron et al., 2004). Abrange rochas de embasamento arqueano a paleoproterozoico, suítes mesoproterozoicas e neoproterozoicas de rochas vulcanossedimentares e sedimentares, granitoides intrusivos neoproterozoicos, sequências sedimentares de margem passiva e granitos tardi-cinemáticos (Campanha \& Sadowski, 1999; Heilbron et al., 2004; Prazeres Filho, 2005). Os cinturões Ribeira Norte e Central compreendem os terrenos Ocidental, Paraíba do Sul-Embu, Oriental e Cabo Frio (Heilbron et al., 2004). O Cinturão Ribeira Meridional encerra os terrenos Socorro, Apiaí, Embú, Curitiba, Luís Alves e Paranaguá (Campos Neto, 2000; Siga Junior et al., 2011). O Terreno Curitiba está limitado a noroeste pelo Grupo Açungui e a sudeste pelo Terreno Luís Alves (Fuck et al., 1967; Siga Junior et al., 1995; Salamuni, 1998). É formado pelo Complexo Atuba e pelas formações supracrustais Capiru, Setuva e Turvo-Cajati. O Complexo Atuba, alvo da presente contribuição, é caracterizado por gnaisses bandados, migmatíticos, intercalados por corpos anfibolíticos, xistos magnesianos e gnaisses granulíticos (Silva et al., 1998).

A área está localizada no leste do Estado do Paraná, na cidade de Curitiba e regiões circunvizinhas, abrangendo os municípios de Colombo, Campo Largo, Balsa Nova, Quitandinha e São José dos Pinhais. Foram estudados oito afloramentos-chave situados nas pedreiras Greca, Central, Inecol, Atuba, Paulo Leminski, Costa, Artecipe e São Jorge, além de afloramentos isolados, localizados em cortes de estrada, escolhidos devido ao interesse estrutural, acesso e representatividade (Figura 1).

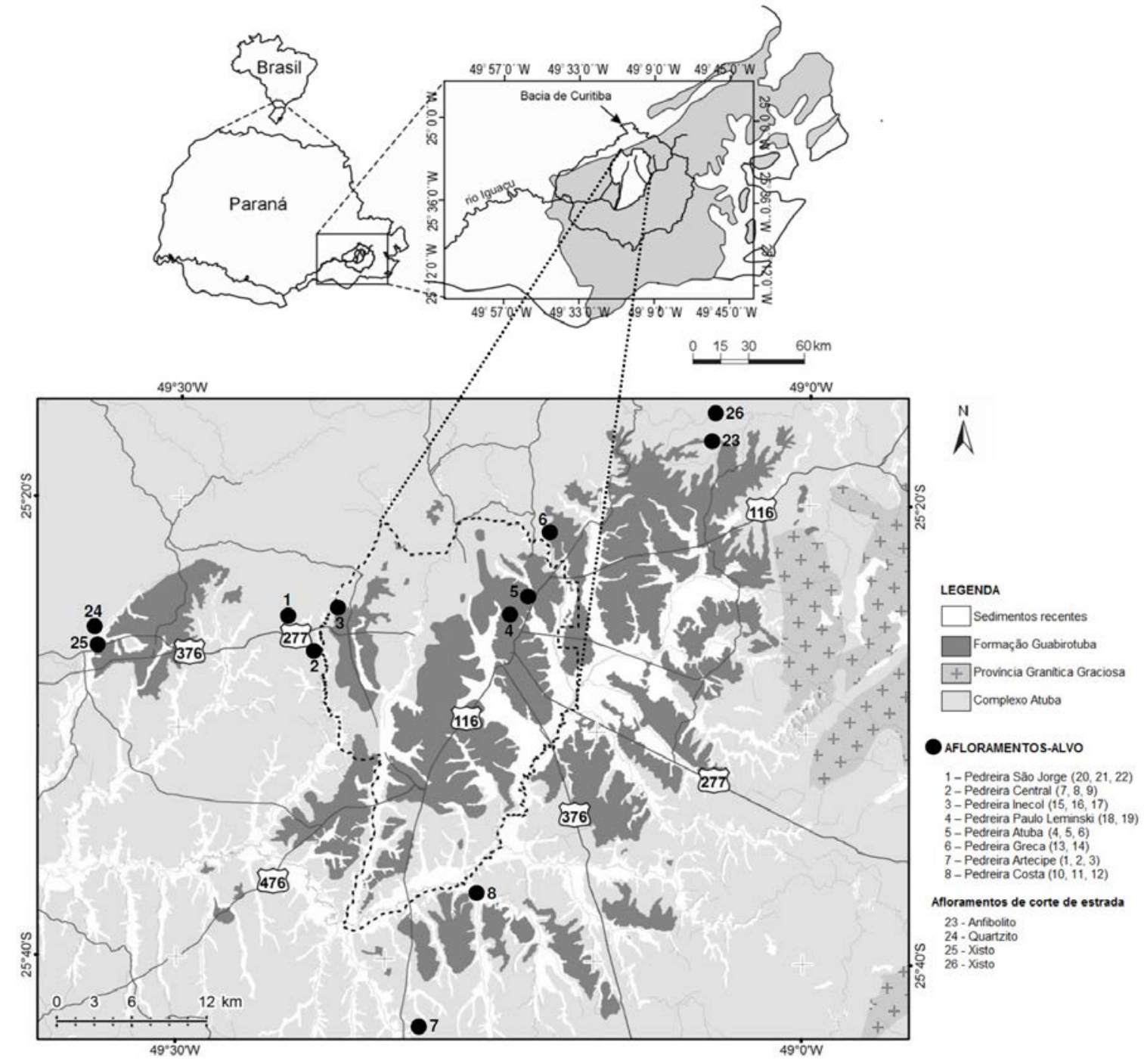

Figura 1: Localização e acessos à área de estudo. Os números entre parênteses e os afloramentos de corte de estrada representam as amostras utilizadas nos métodos de quantificação da deformação. Fonte: modificado de Chavez-Kus \& Salamuni (2008); Cunha (2016). 
A análise da deformação permite explorar o estado de deformação de uma rocha e mapear suas variações em uma amostra, um afloramento ou uma região (Twiss \& Moores, 2007). A deformação quase sempre é o resultado da aplicação de esforços tectônicos e pode ser analisada de acordo com a geometria do estado deformado do objeto, enquanto que a quantidade de deformação é determinada pela comparação entre o estado indeformado e o estado deformado (Fiori, 1997). Os métodos de quantificação da deformação propiciaram grande avanço na geologia estrutural, pois indicam questões importantes e impõem considerações mais claras ao permitir o reconhecimento de estruturas em escalas menores (Sorby, 1908).

As estruturas tectônicas em menor escala resultantes da atuação de processos intra ou intergranulares, necessitam da utilização de métodos de quantificação da deformação específicos, que apresentam diferentes sensibilidades aos diferentes mecanismos de deformação. De acordo com a técnica empregada, a rocha pode mostrar valores distintos de intensidade da deformação em regimes tectônicos dúcteis (Soares \& Dias, 2014). A forma final dos grãos é o resultado da superposição de um elipsoide de deformação sobre a geometria elipsoidal inicial desses grãos (Fiori, 1997), possibilitando que os marcadores de deformação possam ser agrupados em três categorias gerais (Mulchrone, 2013): ponto, geometria e elipse. A carência de trabalhos que discutam a quantificação da deformação dos migmatitos do Complexo Atuba estimulou grande interesse nas pesquisas ora apresentadas. O principal objetivo deste artigo é trazer dados quantitativos, até então limitados ao Complexo Atuba, baseado em quantificação da deformação, utilizando os métodos de Fry (Fry, 1979), Rf/ $\varphi$ (Ramsay, 1967; Ramsay e Huber, 1983; Marshak \& Mitra, 1988; Fiori, 1997) e Polar (Elliott, 1970), colaborando para um melhor entendimento dos processos deformacionais que agem em crosta continental profunda. O modelo desenvolvido neste trabalho para a história da deformação foi definido com base em observações de campo e dados da literatura.

\section{ARCABOUÇO GEOLÓGICO}

A área de estudo está inserida na parte meridional da Província Mantiqueira e contempla parcialmente a porção sul do Cinturão Ribeira, no setor leste do Estado do Paraná (Figura 2). Está localizada no Terreno Curitiba e compõe o Cinturão Ribeira Meridional, juntamente com os terrenos Paranaguá, Apiaí e Luís Alves.

O Terreno Apiaí, parte do Cinturão Ribeira Meridional, compreende uma faixa com $500 \mathrm{~km}$ de extensão e localiza-se ao norte do Terreno Curitiba e a sul-sudeste da Zona de Cisalhamento Lancinha, próximo ao contato com a Bacia do Paraná (Prazeres Filho et al., 2003; Heilbron et al., 2008). É constituído por plataformas carbonáticas, sequências metavulcanossedimentares (Soares \& Reis Neto, 1987; Campos Neto, 2000; Siga Junior et al., 2009; Campanha et al., 2015;) em meio a núcleos do embasamento e batólitos e stocks graníticos (Campanha \& Sadowski, 1999; Cury et al., 2002). O principal evento de metamorfismo e deformação ocorreu no Neoproterozoico (Basei et al., 1992). O estágio final de tectonismo esteve associado a sistemas transcorrentes com colisão oblíqua (Campanha \& Sadowski, 1999).

O Terreno Curitiba, composto por ortognaisses migmatíticos e gnaisses graníticos bandados do
Complexo Atuba, é limitado a norte, em contato com o Terreno Apiaí, pela Zona de Cisalhamento Lancinha-Cubatão-Itariri e a sul pela Zona de Cisalhamento Serra do Azeite, ocupando uma faixa estreita de direção NE-SW, com largura de $20 \mathrm{Km}$ e extensão entre 50 e 60 Km de comprimento (Siga Junior et al., 1993; Siga Junior et al., 1995; Basei et al., 2008; Faleiros et al., 2011).

Os migmatitos possuem estruturas estromáticas e bandamento composicional, onde se alternam mesossomas e leucossomas (Siga Junior, 1995; Siga Junior et al., 1995). Caracterizam-se por frequentes intercalações de corpos com dimensões e formas variadas, constituídas por xistos magnesianos e anfibolitos. Comumente ocorrem remobilizados róseos graníticos (K-feldspato) concordantes com o bandamento principal, relacionados à segunda fase de migmatização (Siga Junior et al., 1995). Estruturalmente ocorre uma foliação milonítica, penetrativa, de aspecto anastomosado, com mergulhos altos para NW ou SE, orientada segundo a direção geral NE-SW. Possui caráter dúctil, heterogêneo e não-coaxial (Siga Junior, 1995; Siga Junior et al., 1995). Também pode ser verificada uma esparsa foliação anterior (Sn- 
1), de direção NW-SE, pouco preservada e com mergulho moderado para NE ou SW (Salamuni, 1998). O Complexo Atuba está em um domínio originado em nível estrutural inferior, acrescido às extremidades do Terreno Luís Alves no Neoproterozoico, porém registrando rochas do Arqueano (3.200 a $3.000 \mathrm{Ma}$ ), Arqueano tardio
(2.650 Ma) e migmatitos do Paleoproterozoico (2.100 Ma e $2.400 \mathrm{Ma}$ ), além de um processo de rejuvenescimento por meio de um segundo processo de migmatização durante o Neoproterozoico (640-560 Ma, K-Ar/Ar-Ar em biotita) (Siga Junior, 1995; Siga Junior et al., 1995; Siga Junior et al., 2007).

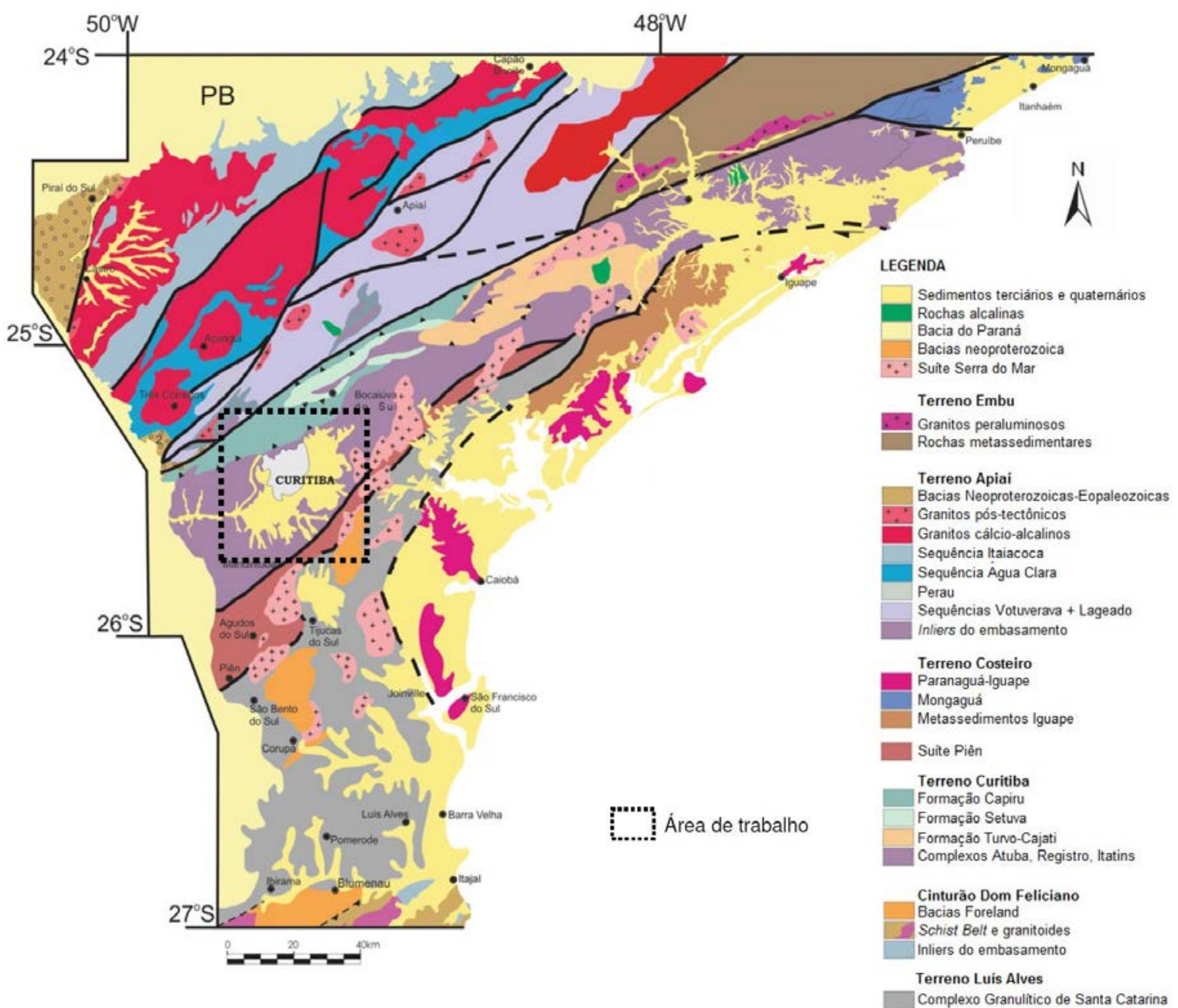

Figura 2: Mapa geológico da porção centro-sul do Cinturão Ribeira. Fonte: modificado de Passarelli et al. (2018).

Unidades metassedimentares supracrustais de plataforma continental cobrem a porção norte do Complexo Atuba e são denominadas de formações Turvo-Cajati, Setuva e Capiru. São constituídas por xisto, mármore dolomítico, quartzito e filito, com metamorfismo entre a fácies xisto verde e anfibolito superior (Sato et al., 2003; Siga Junior et al., 2009; Faleiros et al., 2011). As unidades são afetadas por zonas de cisalhamento rúptil a rúptil-dúctil de direção NESW, em boa parte demarcadas por anomalias gravimétricas negativas (Castro et al., 2014), que demarcam forte deformação no Complexo Atuba, reativadas desde o Mesozoico até idades recentes (Salamuni et al., 2003).

O Terreno Luís Alves, que pode ser considerado um remanescente cratônico, está localizado a sul do Terreno Curitiba e a oeste do Terreno Paranaguá (Faleiros et al., 2011; Cury, 2009). É formado por gnaisses granulíticos (Complexo Serra Negra) de médio a alto grau, maciços, de composição tonalíticogranodiorítica (Hartmann et al., 2000; Sato et al., 2003), com idades arqueanas (2720-2580 Ma, ${ }^{87} \mathrm{Rb} /{ }^{86} \mathrm{Sr}$ ) e paleoproterozoicas (2250-1850 Ma) (Faleiros et al., 2011). Migmatitos, granitos, rochas básicas e ultramáficas, gnaisses calcissilicatados, kinzigitos, formações ferríferas e quartzitos ocorrem de forma subordinada. A foliação está na direção NW-SE e o metamorfismo é caracterizado por fácies granulito, tendo sido acrescido ao Craton Paranapanema durante o Neoproterozoico e é entendido como um terreno alóctone (Basei et al., 2009; Cury, 2009). 
O Terreno Paranaguá está situado na região costeira, em partes de Santa Catarina, Paraná e São Paulo. Prolonga-se por uma faixa de $30 \mathrm{~km}$ de largura e $250 \mathrm{~km}$ de comprimento com faixa principal de direção NE-SW e balizado pelas Zonas de Cisalhamento Palmital, Alexandria, Serra Negra e Icapara (Cury, 2009). É constituído pelas suítes Morro Inglês, Rio do Poço e
Canavieiras-Estrela. As rochas encaixantes são formadas por gnaisses e migmatitos (Complexo São Francisco do Sul) e por rochas metassedimentares (Sequência Rio das Cobras). As idades do magmatismo das suítes Morro Inglês, Rio do Poço e Canavieiras-Estrela estão no intervalo entre 600 a 580 Ma (Siga Junior, 1995; Cury, 2009).

\section{MATERIAIS E METODOS}

A pesquisa foi desenvolvida por meio do levantamento e tratamento dos dados integrados em uma rotina de trabalho, de acordo com os métodos descritos a seguir, subdivididos em itens. Para o trabalho foi confeccionado um banco de dados contendo informações principalmente de artigos e mapas, mas também de dissertações, teses, livros e relatórios.

Os levantamentos foram realizados em escala de detalhe, conectado às questões regionais do Terreno Curitiba. As campanhas de campo buscaram a análise estrutural em escala mesoscópica, a classificação de feições estruturais dúcteis a partir de coleta e confecção de lâminas delgadas e, por fim, a análise da quantificação da deformação pelo método de Fry, Polar e Rf/ $\varphi$. A seguir serão descritos os métodos mais importantes para a confecção do trabalho.

\section{Análise estrutural}

Para a análise estrutural foi observada a distribuição das relações de contato entre os corpos amostrados, a geometria das foliações e lineações, a hierarquização dos elementos estruturais e a caracterização cinemática em lâminas delgadas na escala microscópica. Os critérios de análise descritiva e cinemática seguiram os conceitos de Ramsay (1980) e Fossen (2012). As estruturas lineares obedeceram a classificação sugerida por Twiss \& Moores (2007). Os dados estruturais foram organizados em uma tabela Excel (Office ${ }^{\circledR}$ ) e o tratamento estatístico dos dados foi realizado no software Stereo 32 e GeotecStereo (Fronza et al., 2016). Para a análise estrutural das foliações, os intervalos foram agrupados estatisticamente em baixo $\left(0^{\circ}-30^{\circ}\right)$, médio $\left(31^{\circ}-60^{\circ}\right)$ e alto ângulo de mergulho $\left(61^{\circ}-90^{\circ}\right)$.

\section{Quantificação da deformação}

Amostras orientadas foram coletadas em campo e posteriormente foram definidos os cortes onde seriam confeccionadas as lâminas delgadas. Para a seleção das lâminas mais adequadas para a aplicação das técnicas foram utilizadas as descrições petrográfica e microestrutural. Foram analisados migmatitos metatexitos estromáticos e granitoides, além de xistos, anfibolitos e quartzitos. As amostras foram coletadas nos domínios de feições de baixo a alto ângulo de mergulho a partir das foliações Sn-1 e Sn. Na quantificação finita foram utilizados como marcadores de deformação a distribuição dos grãos de quartzo ou feldspatos observados em fotomicrografias. Para caracterizar a deformação em termos de tipo e de intensidade, foram analisadas 60 lâminas delgadas, cortadas nos planos cinemáticos XZ e YZ. Também foram feitos cortes aleatórios para o cálculo do elipsoide. Os cristais de feldspatos ou quartzo foram pontuados no método de Fry (Fry, 1979) e poligonizados nos métodos $\mathrm{Rf} / \varphi$ (Ramsay, 1967) e Polar (Elliott, 1970), com auxílio do software EllipseFit 3.3.0, levando-se em consideração que o método de Fry é sensível tanto à deformação intragranular como intergranular, enquanto os métodos $\mathrm{Rf} / \varphi$ e Polar apenas são sensíveis aos processos intragranulares (Ramsay e Huber, 1983; Elliott, 1970). Os cálculos desenvolvidos durante o trabalho foram realizados com o software EllipseFit 3.6.2 (Vollmer, 2017). A obtenção da quantificação da deformação obedece a três etapas fundamentais: amostragem, processamento da fotomicrografia e determinação dos métodos em cada seção (Figura 3).

A pesquisa baseou-se em questões geológicas de trama e de deformação, determinando a tensão bidimensional e tridimensional utilizando fotografias orientadas. O EllipseFit foi executado em plataforma Windows e os arquivos foram salvos em formatos de planilha simples, compatíveis com softwares como o Microsoft Excel e o LibreOffice Calc.

\section{Método de Fry}

O método de Fry (1979) considera a distribuição dos centros dos marcadores (cristais de feldspato ou quartzo) e reflete a deformação total da amostra. O procedimento proporciona a 


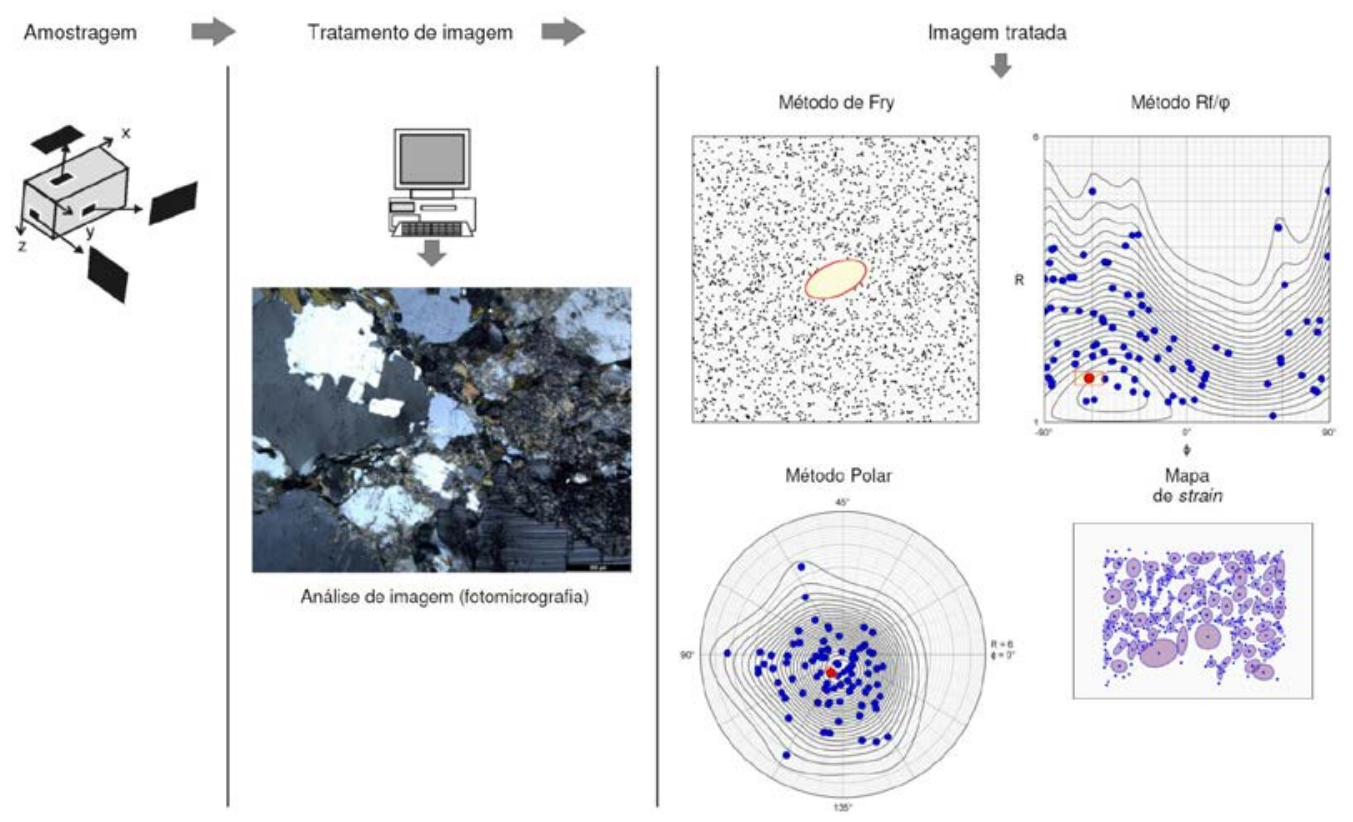

Figura 3: Aquisição da imagem, procedimentos e determinação dos métodos de quantificação da deformação. Fonte: modificado de Rodrigues et al. (2009).

análise qualitativa da taxa de deformação. O cálculo da deformação de uma amostra de pontos deve ser objetivo, não exigindo que um usuário determine subjetivamente a elipse de melhor ajuste. Os métodos atualmente implementados no EllipseFit são acessados por meio da interface Fit Void. Kumar et al. (2014) testaram seis desses métodos e concluíram que o exponential edge detection (Waldron \& Wallace, 2007) é o menos afetado pelo grau de seleção, natureza ou a quantidade de distorção. Essa ferramenta não requer informações de forma da partícula, o que lhe dá vantagem em termos de velocidade de coleta de dados (Waldron \& Wallace, 2007).

O método maximiza a função exponencial, calculada para todos os pontos no raio de pesquisa. Esse procedimento localiza a elipse que define a borda do vazio, procurando o gradiente de densidade mais acentuado. Os parâmetros são o raio longo da elipse, raio curto e orientação. O parâmetro $\mathrm{k}$ é definido por padrão como $\mathrm{k}=3$, conforme sugerido por Waldron \& Wallace (2007).

Para utilização do método de Fry foi selecionada uma amostra com quantidade razoável de cristais de feldspatos ou quartzo, suficientes para utilização do método. Foram escolhidos pelo menos 60 centros de partículas, que é um número mínimo provável para análise (Shan \& Xiao, 2011).

Para calcular o elipsoide de deformação foram utilizados os dados do método de Fry. Para tanto, foram confeccionadas três seções delgadas na mesma amostra. Os cálculos foram elaborados nas amostras Artecipe 1, Atuba 4, Central 7,
Costa 10, Greca 13, Inecol 16, Leminski 19 e São Jorge 22. Os cortes foram realizados em médios e altos ângulos de mergulho. O método utilizado para o cálculo de elipsoides de trama foi o método de Shan (Shan, 2008), que reconhece que o menor autovetor da matriz de dados é a solução ótima. Para o cálculo de elipsoide utilizando o método de Shan, o EllipseFit determina os eixos principais do elipsoide como lineação de estiramento e suas orientações como direção e mergulho. Resíduos de desajuste são calculados para cada elipse da seção para auxiliar na detecção de erros, como seções incorretamente orientadas (Vollmer, 2017). As figuras geradas nesse processo foram os diagramas de Flinn, Nadai-Hsü e elipsoides de deformação.

Para as outras amostras que não utilizaram o cálculo do elipsoide de deformação, por possuírem apenas dois cortes (planos XZ e YZ), foram utilizadas o método de Hossack (1968), também disponibilizado no software EllipseFit. Nesse caso, também foram confeccionados os diagramas de Flinn e Nadai-Hsü.

\section{Método Rf/ $\varphi$ e Método Polar}

O método Rf/ $\varphi$ (Ramsay, 1967) é uma trama cartesiana de Rf ou mais comumente log natural Rf versus $\varphi$ e, é amplamente utilizado na análise de deformação. Esse método é provavelmente mais reconhecido e usado do que o método Polar de Elliott, mas tem mais distorção em baixas deformações (Vollmer, 2017) e analisa apenas os marcadores, sem considerar a matriz (Lislie, 1985).

O método Polar de Elliott (Elliott, 1970) é uma trama polar do log natural $\mathrm{R}$ versus $2 \varphi \mathrm{e}$ 
pode ser considerada uma projeção azimutal equidistante (Yamaji, 2008). Embora todas as projeções tenham distorção inerente, essa trama não distorce a magnitude da deformação radialmente e, portanto, geralmente fornece uma melhor representação dos dados do que o gráfico $\mathrm{Rf} / \varphi$.

Para os métodos $\mathrm{Rf} / \varphi$ e Polar foram utilizados o comando Polígono no software EllipseFit, pelo qual uma partícula é convertida em polígono usando tantos pontos quanto necessários. Posteriormente o polígono é transformado em elipse, contendo área, centro de massa e inércia (Vollmer, 2017). Outra projeção desenvolvida nesta pesquisa empregando o software EllipseFit é o mapa de deformação (strain map). Os eixos dos elipsoides de deformação foram elaborados em diagramas de Schmidt no software Orient 3.10 .

\section{RESULTADOS}

São apresentados os resultados da análise estrutural e quantificação da deformação das rochas do Complexo Atuba. A área de trabalho é formada por migmatitos metatexitos estromáticos, gnaisses granulíticos, diatexitos schollen, anfibolitos, granitoides, quartzitos e xistos. O neossoma residual mesocático é caracterizado por anfibólio-biotita gnaisse mesocrático cinzento, tonalítico, de granulação média a grossa. A primeira fase de migmatização é constituída por leucossomas brancos, foliados, dobrados, centimétricos, granodioríticos a tonalíticos (plagioclásio + quartzo + K-feldspato), paralelos à foliação ou bandamento principal. O melanosoma possui diopsídio, enstatita e granada. Encontra-se nas bordas do leucossoma, com espessura milimétrica. A segunda fase é formada por leucossomas róseos ou brancos, graníticos (Kfeldspato + quartzo + plagioclásio), milimétricos a métricos, maciços ou levemente foliados, concordantes com a foliação da rocha. Podem estar dobrados e boudinados. O melanossoma tem biotita e anfibólio. É milimétrico, cinza escuro e ocorre paralelamente ao leucossoma. A primeira fase é observada nas pedreiras Artecipe, Central, Greca e Inecol. Já a segunda fase ocorre com mais proeminência nas pedreiras Artecipe, Atuba, Costa, Inecol e São Jorge.

\section{Estruturas}

Aqui são analisadas as principais estruturas dúcteis presentes na área de estudo do Complexo Atuba, obtidas a partir de atitudes estruturais e descrição geométrica. Para tanto, foi necessário uma triagem dos dados de campo, a partir das medidas de foliação (Sn-1 e Sn), lineação de estiramento mineral, boudins e dobras. Os principais litotipos e estruturas são apresentados nas figuras 4 e 5 , respectivamente.
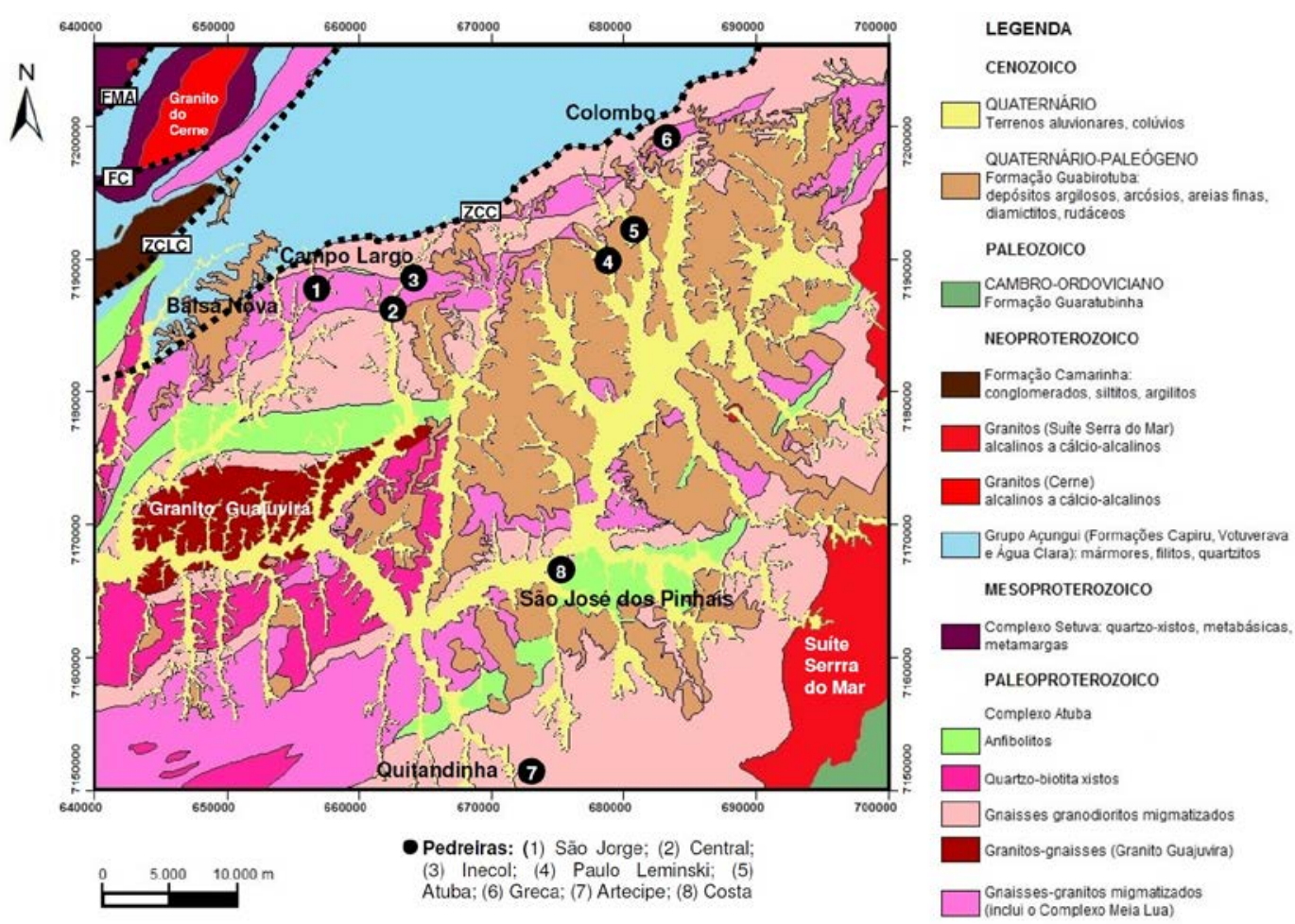

Figura 4: Mapa geológico simplificado da porção leste do Estado do Paraná, evidenciando o Complexo Atuba e arredores. Falhas e zonas de cisalhamento: FMA (Falha do Morro Agudo); FC (Falha do Cerne); ZCLC (Zona de Cisalhamento Lancinha-Cubatão); ZCC (Zona de Cisalhamento Curitiba). Fonte: modificado de Salamuni (1998). 


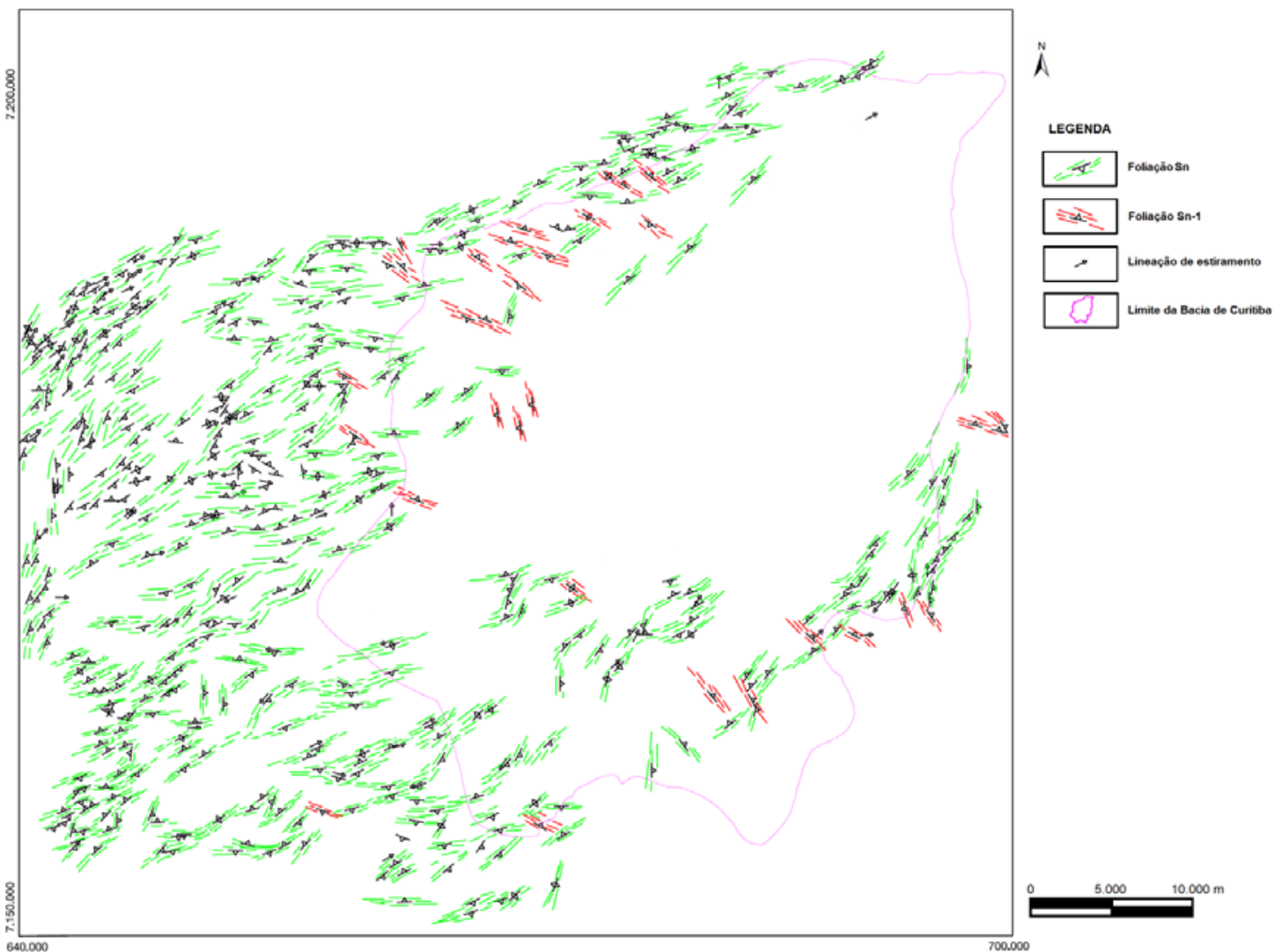

Figura 5: Trajetórias das foliações encontradas na área de trabalho. Fonte: modificado de Salamuni (1998).

\section{Sn-1}

Os migmatitos metatexitos estromáticos são cinza médio, listrados, formados pela alternância entre o neossoma residual mesocrático tonalítico, leucossoma granodiorítico a tonalítico e melanossoma máfico.

A foliação Sn-1 (Figura 6A) está relacionada à tectônica de cavalgamento de baixo ângulo de mergulho (Dn-1), porém ocorre de forma rotacionada e até verticalizada em algumas regiões do Complexo Atuba. É observada nas pedreiras Artecipe, Central, Greca, Inecol e Paulo Leminski. Também ocorre em cortes de estrada. O bandamento composicional se carac-

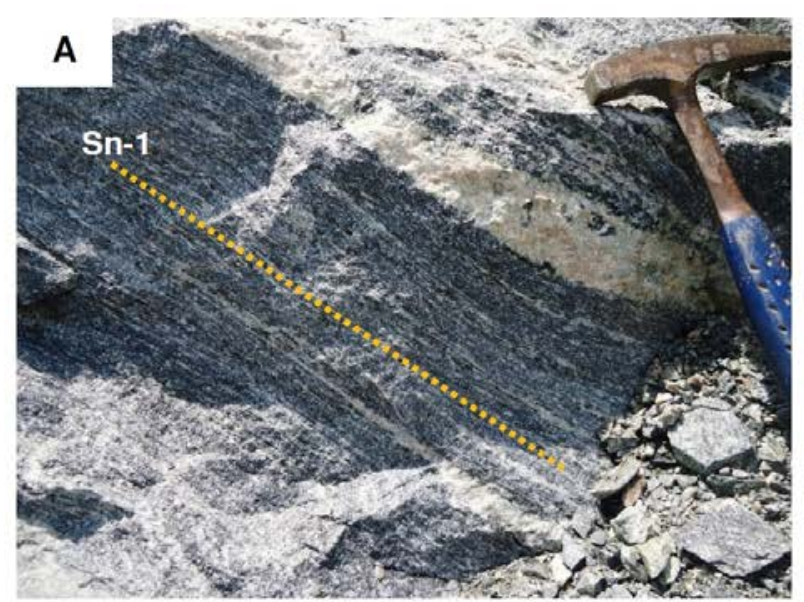

teriza por bandas milimétricas a centimétricas, quartzo-feldspáticas, contínuas, sub-horizontais, não raramente irregulares, intercaladas com bandas milimétricas a centimétricas, de granulação fina a média, formadas por cristais de biotita e/ou anfibólio.

Os cristais apresentam tamanho variável e limites lobados. Os grãos de quartzo exibem contatos irregulares, extinção ondulante, subgrãos, textura semelhante ao tabuleiro de xadrez (Figura 6B) e podem ser intersticiais. A andesina ou oligoclásio tem maclas deformacionais, kink bands e novos grãos. O microclínio mostra extinção ondulante e novos grãos.

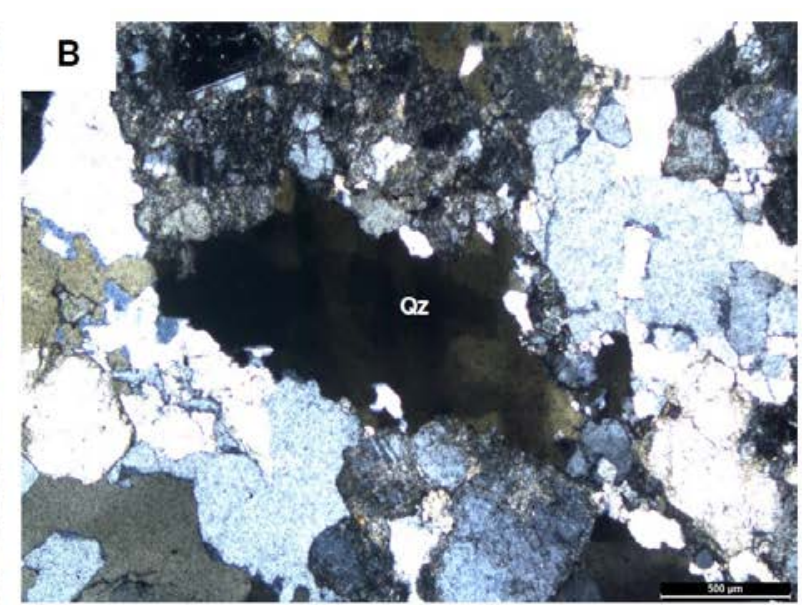

Figura 6: (A) Aspecto macroscópico da foliação Sn-1, caracterizada pela orientação de biotita e estiramento do feldspato. A orientação é N50W/45NE. Local: pedreira Inecol. (B) Quartzo com textura em tabuleiro de xadrez (polarizadores cruzados). Local: pedreira Artecipe. LEGENDA: Qz - quartzo. 

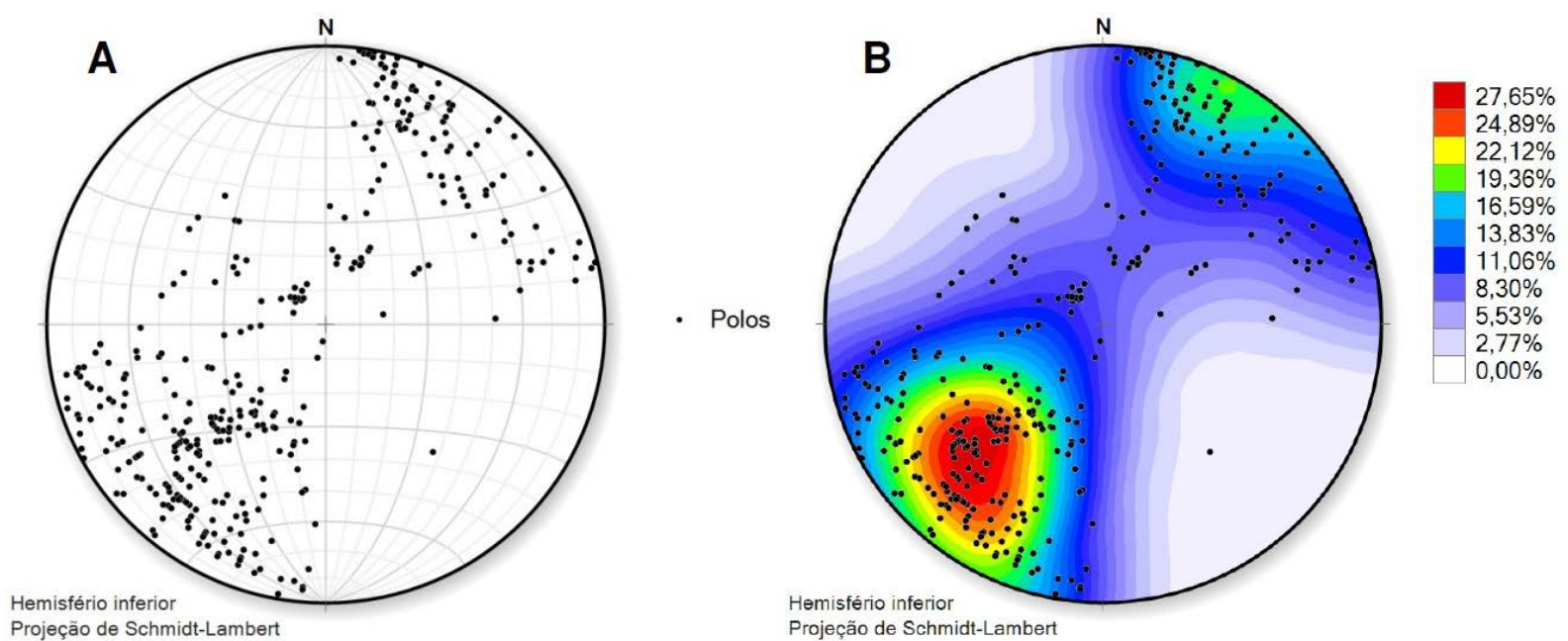

Figura 7: Diagramas estruturais da foliação Sn-1. (A) Representação dos polos. (B) Diagrama de contorno de polos máximos. Schmidt-Lambert, hemisfério inferior. $\mathrm{N}=331$.

A foliação Sn-1 possui direção geral NW-SE e mergulhos baixos a altos para SW ou NE (Figura 7A e B). A atitude mediana dos planos é N45W/55NE, porém os planos podem apresentar-se dobrados, com direção para NESW e mergulhos baixos a médios para SE. Ocorrem dispersões de polos nos quadrantes NE e SW, relacionados a dobras geradas por um evento de cisalhamento posterior. A superfície mostra caráter dúctil, heterogêneo,

anastomosado, penetrativo e descontínuo. Ocorre textura protomilonítica com moderada orientação dos minerais máficos. É definida pela recristalização do quartzo e feldspatos, possuindo cristais com sombras de pressão, reorientação da biotita, estiramento ou achatamento mineral, estruturas S-C e dobras shear-folds assimétricas e centimétricas (Figura 8A), desenhadas pelo leucossoma. Pode exibir feição boudinada e sigmoidal.
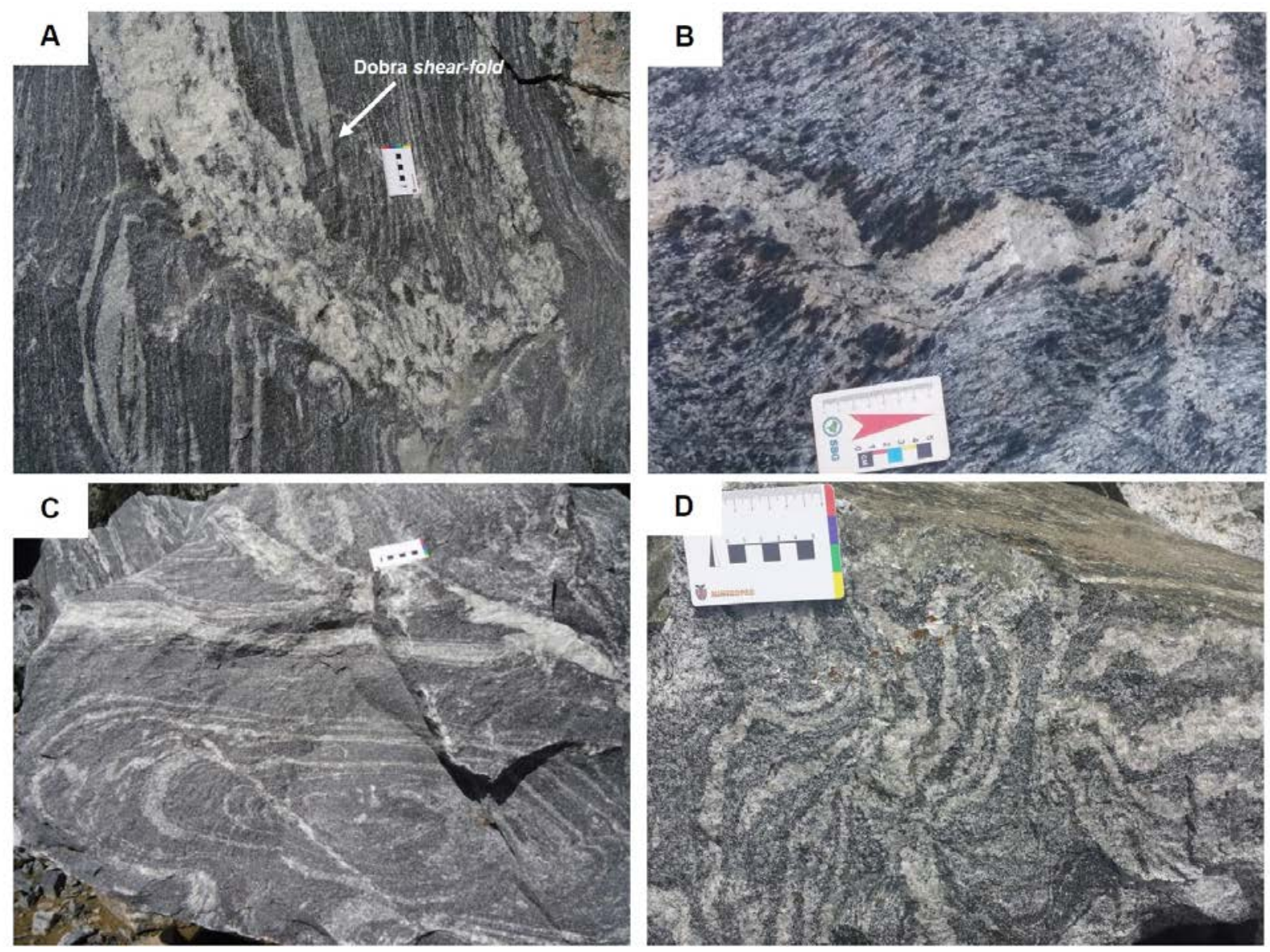

Figura 8: (A) Dobras shear-folds definida pelo leucossoma e o melanossoma com flanco rompido, em forma de cabo de guarda-chuva. Local: pedreira Artecipe. (B) Dobras assimétricas, cortadas pelo neossoma quartzo-feldspático. Local: pedreira Central. (C) Dobras em bainha. Local: pedreira Artecipe. (D) Redobramento de interferência do tipo 3, formando padrão em laço ou em chama. Local: pedreira Inecol. 
Há dobras centimétricas a métricas, intrafoliares, assimétricas (Figura 8B), inclinadas, heterogêneas, com ângulo interflancos variando entre aberta e fechada. Podem estar cortadas obliquamente pelo neossoma. Tanto o leucossoma quanto o neossoma residual mesocrático estão dobrados. Os eixos têm direção média N25/20, e N160/30 e N215/15. Pode haver dobras ptigmáticas, dobras em bainha (Figura 8C) e dobras de fluxo. Encontram-se evidências de redobramento na pedreira Inecol (Figura 8D) e Artecipe, do tipo 3 de Ramsay (1967). A lineação de estiramento mineral tem orientação N80/20, N130/40 e N250/20. Pode ser caracterizada pelo estiramento de biotita e feldspatos (Figura 9).

Por meio de indicadores cinemáticos de escala macroscópica e microscópica como dobras assimétricas, zonas de cisalhamento, pórfiroclastos de oligoclásio assimétricos (Figura 10A) e boudins (Figura 10B), juntamente com as relações da foliação Sn-1, foi possível identificar o sentido de movimento de topo para WSW ou SW. Porém, existem zonas de cisalhamento que exibem cinemática de topo para NE.

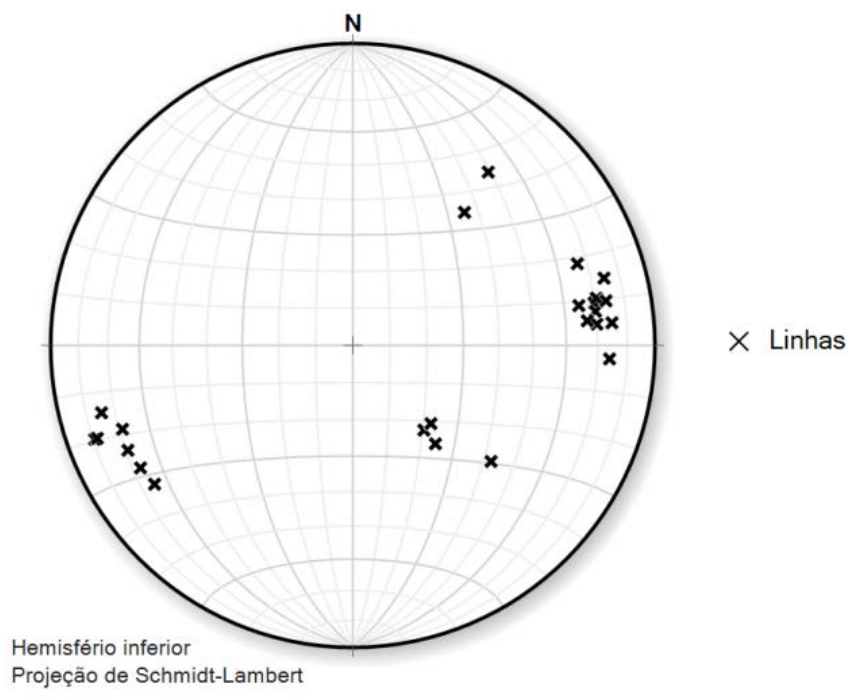

Figura 9: Estereograma de lineações de estiramento mineral para a foliação Sn-1. Schmidt-Lambert, hemisfério inferior. N = 24 .
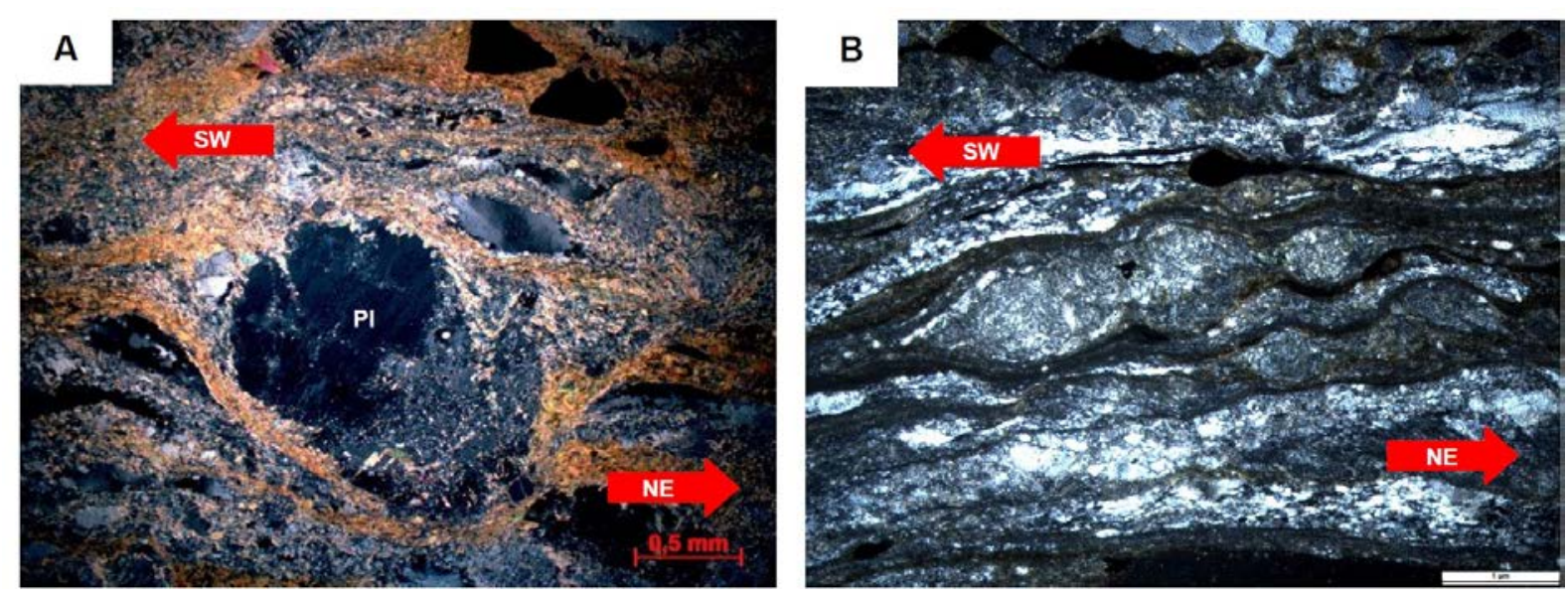

Figura 10: (A) Porfiroclasto de oligoclásio com sombras de pressão, indicando movimentação de topo para SW (polarizadores cruzados). Local: pedreira Greca. (B) Boudins milimétricos, assimétricos, sugerindo transporte de topo para SW (polarizadores cruzados). Local: pedreira Greca. LEGENDA: Pl - plagioclásio.

\section{Sn}

A foliação Sn encontra-se nas pedreiras Artecipe, Atuba, Costa, Greca e São Jorge (Figura 11A). Também pode ser observada em cortes de estrada. Foi desenvolvida pela tectônica transpressiva (Dn) particionada. É paralela ou sub-paralela ao bandamento composicional mesocrático e, eventualmente, se apresenta dobrada. Estruturalmente, a foliação Sn corresponde a uma superfície de transposição (Figura 11B) e obliteramento parcial do bandamento composicional do neossoma residual mesocrático. Mostra feldspatos rotacionados, sigmoides, recristalização mineral moderada, estiramento, par S-C, reorientação dos minerais micáceos e quartzo-feldspáticos, estruturas de boudinagem e dobras macroscópicas, além de protomilonitos, milonitos e ultramilonitos, segundo a classifi- 
cação de Sibson (1977). A foliação em geral possui geometria planar a ondulada, contínua, irregular, heterogênea, com espaçamento milimétrico a métrico e caráter penetrativo na escala mesoscópica. Localmente encontra-se anastomosada ou com formato lenticular. Tem direções variáveis entre N5E a N88E e mergulhos baixos a altos para NW ou SE (Figura 12A e B). A atitude mediana dos planos é N45E/85NW.
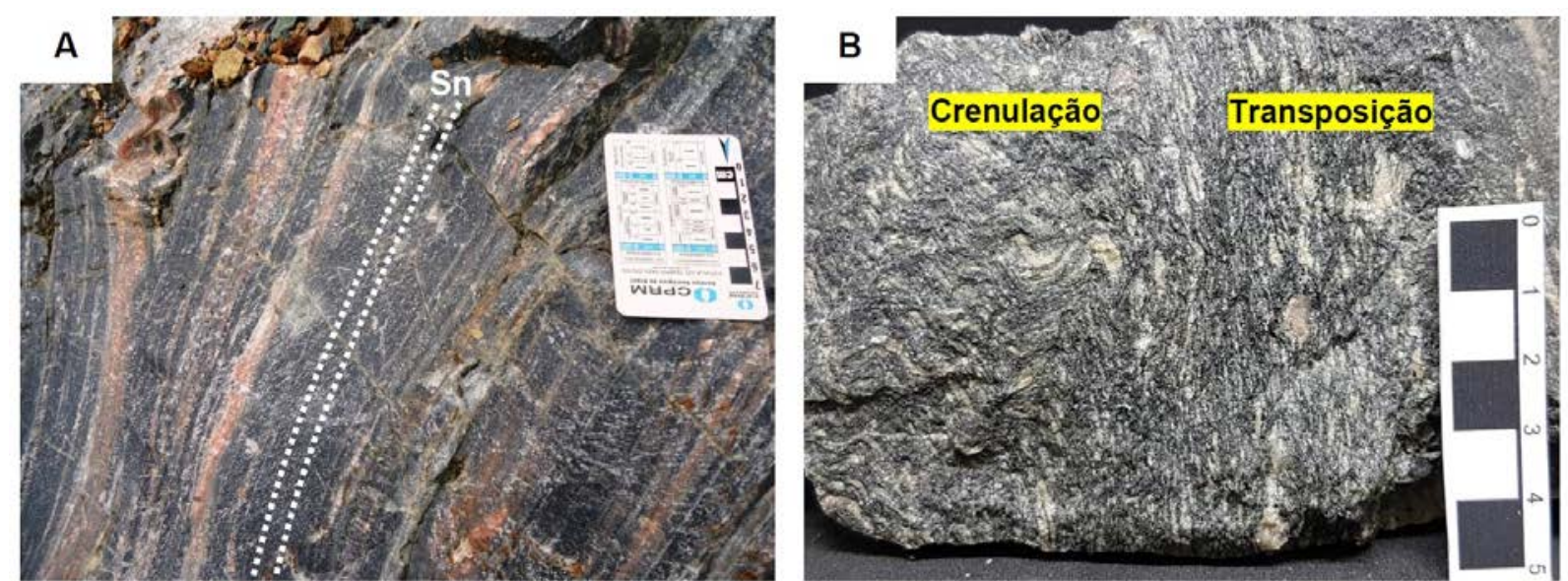

Figura 11: (A) Foliação Sn caracterizada pela orientação de faixas regulares compostas por leucossoma róseo e melanossoma cinza escuro. Ocorre estiramento de feldspatos e níveis orientados e anastomosados de biotita e epidoto. Local: pedreira São Jorge. (B) Foliação de baixo ângulo transposta pela foliação Sn de alto ângulo de mergulho. Local: pedreira São Jorge.
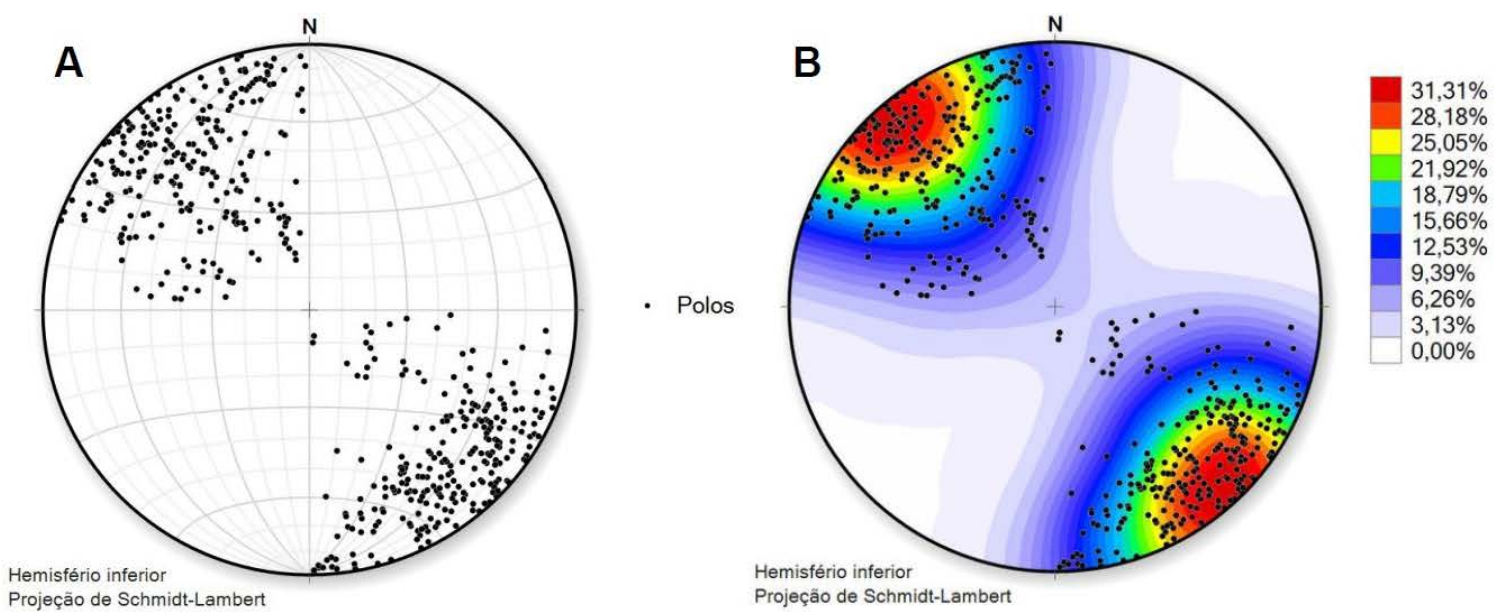

Figura 12. Diagramas estruturais da foliação Sn. (A) Representação dos polos. (B) Diagrama de contorno de polos máximos. Schmidt-Lambert, hemisfério inferior. $\mathrm{N}=594$.

Os cristais de oligoclásio mostram microfraturas, extinção ondulante, maclas deformacionais, rara geminação do tipo albita-periclina e novos grãos. Os cristais de microclínio são caracterizados por microfraturas, extinção ondulante, subgrãos e novos grãos (Figura 13A). Os cristais de hornblenda podem mostrar geminação simples, microfraturas e extinção ondulante. Os cristais de quartzo apresentam contatos irregulares, ribbons, extinção ondulante, bandas de deformação e subgrãos. Os cristais de biotita estão fortemente orientados, com contatos retilíneos. Mostram extinção ondulante e ocorrem em níveis máficos intercalados com níveis quartzo-feldspáticos. Os cristais de clorita exibem orientação (Figura 13B), extinção ondulante e clivagem encurvada. Os cristais de epidoto ocorrem fraturados, com extinção ondulante. Encontram-se orientados e aparecem junto à biotita.

As dobras mostram flancos com atitudes médias em torno de N25E/45SE e N35E/60NW. $\mathrm{O}$ valor do mergulho dos eixos é baixo (entre $5^{\circ}$ e $20^{\circ}$ ) e a vergência, em geral, é para SE. As rochas apresentam dobras intrafoliares (Figura 13C) shear-folds, dobras em bainha, dobras ptigmáticas e dobras em cúspide.

Os boudins (Figura 13D) são assimétricos e arredondados. Estão situados na porção leucocrática, branca ou rósea, formada por quartzo e feldspatos. O comprimento de onda é de $10 \mathrm{~cm}$ a $1 \mathrm{~m}$ e a largura varia de $5 \mathrm{~cm}$ a $1 \mathrm{~m}$. Muitos dos domínios estromáticos podem exibir estruturas pinch-and-swell. 

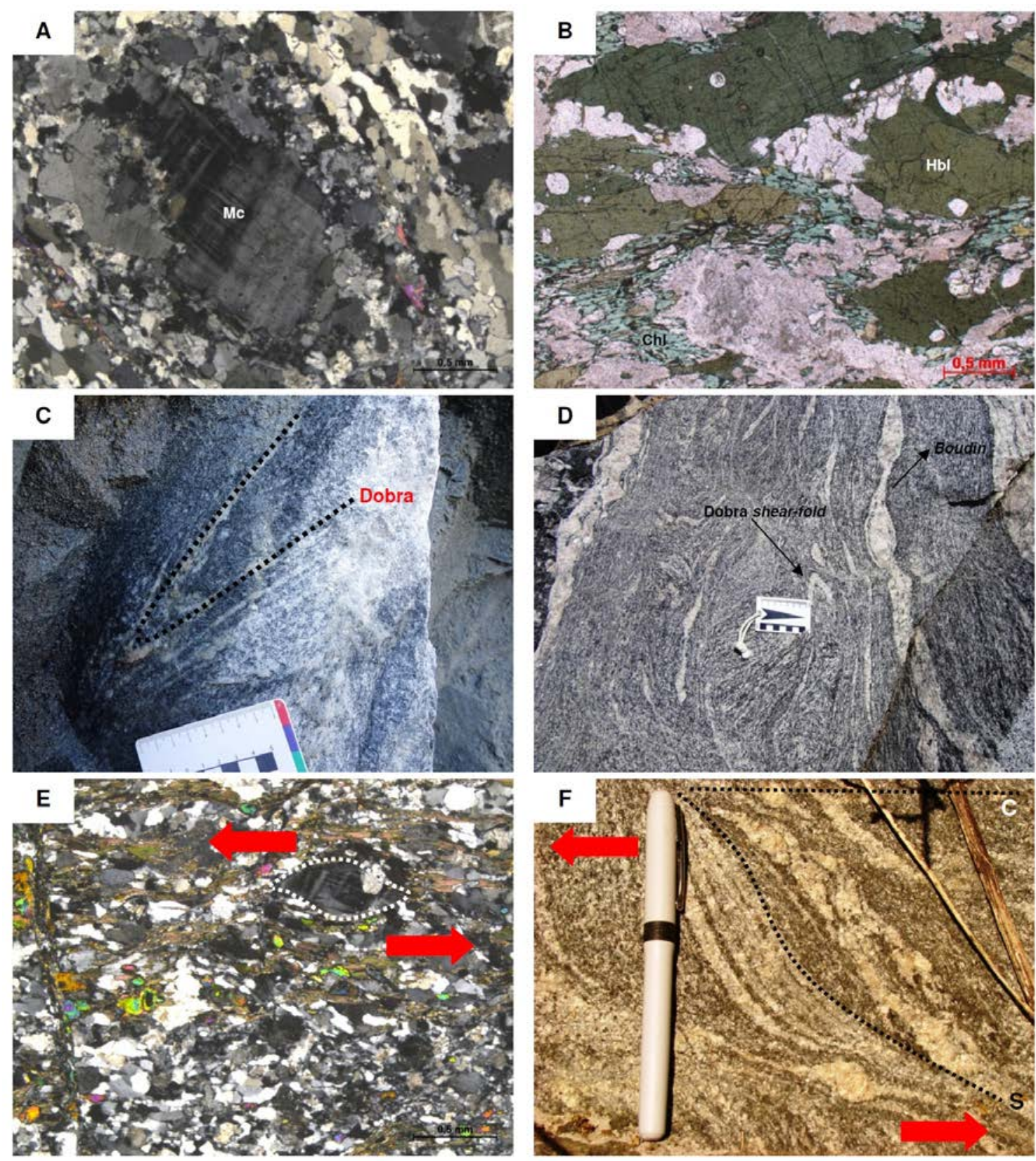

Figura 13: (A) Cristal de microclínio com geração de novos grãos finos por bulging nas bordas (luz com polarizadores cruzados). Local: pedreira São Jorge. (B) Cristais de clorita e hornblenda fortemente orientados (luz com polarizadores cruzados). Local: pedreira Costa. (C) Aspecto macroscópico das dobras intrafoliares centimétricas. Local: pedreira Costa. (D) Boudins em nível leucocrático e dobras shear-folds centimétricas. Local: pedreira Atuba. (E) Sigmoide sinistral de feldspato em metatexito estromático. (F) Par S-C com orientação sinistral para a foliação Sn. LEGENDA: Mc microclínio. Hbl - hornblenda. Chl - clorita.

Os indicadores cinemáticos, como sigmoides de feldspatos (Figura 13E), foliação oblíqua, sombras de pressão, agregados quartzo-feldspáticos e estruturas S-C (Figura 13F), indicam movimentação sinistral. As lineações de estiramento mineral incluem feldspatos estirados, augens de plagioclásio e minerais micáceos orientados. Apresentam atitudes gerais N25/24, N40/04, N40/20, N54/5, N230/10 e 326/72.

Há veios de quartzo de cor branca, pouco a fortemente fraturados, com espessura de 0,1 a 30 $\mathrm{cm}$. Ocorrem paralelos à foliação $\mathrm{Sn}$ dos migmatitos metatexitos estromáticos. Podem estar foliados, boudinados e dobrados. Ocorrem nas pedreiras Costa, Atuba, Inecol e São Jorge. Os cristais de quartzo são finos a médios $(0,2$ a 2 $\mathrm{mm}$ ), anédricos granulares, com contatos serrilhados e curvos. Apresentam subgrãos, estiramento e extinção ondulante.

Os veios de epidoto estão dispostos paralelamente ou discordantes ao bandamento composicional dos migmatitos. Tem cor verde e espessura centimétrica (até $3 \mathrm{~cm}$ ). Ocorrem nas pedreiras Central, São Jorge e Costa.

\section{Quantificação da deformação}

A quantificação da deformação foi estudada em 
26 rochas. As amostras 1, 7, 8, 9, 13, 14, 15, 18 e 19 são caracterizadas pela foliação (Sn-1). O grupo formado pelas amostras 2, 3, 4, 5, 6, 10, 11, 12, 16, 17, 20, 21, 22, 23, 24, 25 e 26 correspondem à foliação (Sn) (Figura 1). Nas amostras 13, 14, 20, 21, 22, 24, 25 e 26 foi utilizado o quartzo como marcador da deformação, enquanto que nas demais foram utilizados os cristais de feldspatos.

\section{Método de Fry}

A análise pelo método de Fry foi realizada em metatexitos estromáticos representativos e rochas associadas, com foliação caracterizada pela orientação moderada de feldspatos, hornblenda e biotita. A lineação mineral é definida pelo alinhamento dos feldspatos ou biotita. Em seção delgada, a rocha apresenta-se moderadamente deformada. Os gráficos de Fry que possuem elipses azul e vermelha em conjunto utilizaram o método exponential edge detection. A elipse azul é a solução inicial estimada automaticamente escolhida utilizando o botão Set no EllipseFit, enquanto a vermelha define a melhor elipse de ajuste do vazio.

Os valores gerais (foliações Sn-1 e Sn) da razão de deformação (R) obtidos nas amostras para os cristais de quarto variam entre 4,984 a 1,864 no plano XZ e 2,567 a 1,217 no corte YZ (Tabela 1).

Tabela 1: Parâmetros de deformação obtidos pelo método de Fry. LEGENDA: N: número de medidas. A: raio máximo da elipse. B: raio mínimo da elipse. R: razão da elipse = a/b. $\phi$ : orientação do maior eixo da elipse.

\begin{tabular}{|c|c|c|c|c|c|c|c|}
\hline Amostra & Artecipe 1a & Artecipe 1b & Artecipe 1c & Artecipe 2a & Artecipe 2b & Artecipe 3a & Artecipe 3b \\
\hline $\mathbf{N}$ & 71 & 62 & 60 & 297 & 235 & 60 & 70 \\
\hline $\mathbf{A}$ & 88,718 & 101,908 & 60,264 & 27,160 & 26,511 & 0,903 & 0,923 \\
\hline B & 42,121 & 49,731 & 36,684 & 13,238 & 15,165 & 0,497 & 0,641 \\
\hline $\mathbf{R}$ & 2,106 & 2,049 & 1,643 & 2,052 & 1,748 & 1,814 & 1,441 \\
\hline$\Phi$ & $88,15^{\circ}$ & $104,65^{\circ}$ & $137,95^{\circ}$ & $143,85^{\circ}$ & $53,83^{\circ}$ & $61,90^{\circ}$ & $51,86^{\circ}$ \\
\hline Amostra & Atuba 4a & Atuba 4b & Atuba 4c & Atuba 5a & Atuba 5b & Atuba 6a & Atuba 6b \\
\hline $\mathbf{N}$ & 50 & 102 & 51 & 180 & 128 & 60 & 60 \\
\hline A & 121,543 & 45,982 & 56,265 & 46,004 & 32,281 & 0,889 & 0,899 \\
\hline B & 76,718 & 29,707 & 38,839 & 25,023 & 17,847 & 0,502 & 0,592 \\
\hline $\mathbf{R}$ & 1,584 & 1,548 & 1,449 & 1,838 & 1,809 & 1,770 & 1,517 \\
\hline $\boldsymbol{\Phi}$ & $8,39^{\circ}$ & $126,33^{\circ}$ & $144,01^{\circ}$ & $13,21^{\circ}$ & $37,98^{\circ}$ & $2,92^{\circ}$ & $4,13^{\circ}$ \\
\hline Amostra & Central 7a & Central 7b & Central 7c & Central 8a & Central 8b & Central 9a & Central 9b \\
\hline $\mathbf{N}$ & 66 & 69 & 55 & 90 & 104 & 60 & 61 \\
\hline A & 75,870 & 34,266 & 103,000 & 56,160 & 44,311 & 0,642 & 0,584 \\
\hline B & 26,045 & 23,767 & 90,338 & 31,371 & 32,188 & 0,582 & 0,565 \\
\hline $\mathbf{R}$ & 2,913 & 1,442 & 1,140 & 1,790 & 1,377 & 1,103 & 1,035 \\
\hline$\Phi$ & $14,51^{\circ}$ & $157,59^{\circ}$ & $45,40^{\circ}$ & $39,94^{\circ}$ & $47,33^{\circ}$ & $179,87^{\circ}$ & $146,62^{\circ}$ \\
\hline Amostra & Costa 10a & Costa 10b & Costa 10c & Costa 11a & Costa 11b & Costa 12a & Costa 12b \\
\hline $\mathbf{N}$ & 65 & 60 & 80 & 60 & 62 & 61 & 61 \\
\hline A & 91,090 & 96,554 & 49,462 & 59,005 & 48,956 & 54,519 & 41,530 \\
\hline B & 42,920 & 51,753 & 26,803 & 26,541 & 37,186 & 31,549 & 34,268 \\
\hline $\mathbf{R}$ & 2,122 & 1,866 & 1,845 & 2,223 & 1,317 & 1,728 & 1,212 \\
\hline$\Phi$ & $160,07^{\circ}$ & $32,23^{\circ}$ & $133,16^{\circ}$ & $141,18^{\circ}$ & $36,62^{\circ}$ & $19,89^{\circ}$ & $171,00^{\circ}$ \\
\hline Amostra & Greca 13a & Greca 13b & Greca 13c & Greca 14a & Greca 14b & Inecol 15a & Inecol 15b \\
\hline $\mathbf{N}$ & 122 & 100 & 60 & 237 & 74 & 109 & 225 \\
\hline A & 60,897 & 36,385 & 53,742 & 30,362 & 17,391 & 66,774 & 30,001 \\
\hline B & 17,520 & 17,378 & 28,288 & 8,768 & 8,307 & 37,633 & 21,942 \\
\hline $\mathbf{R}$ & 3,476 & 2,094 & 1,900 & 3,463 & 2,094 & 1,774 & 1,367 \\
\hline$\Phi$ & $89,91^{\circ}$ & $146,07^{\circ}$ & $118,65^{\circ}$ & $24,01^{\circ}$ & $5,68^{\circ}$ & $118,81^{\circ}$ & $111,03^{\circ}$ \\
\hline Amostra & Inecol 16a & Inecol 16b & Inecol 16c & Inecol 17a & Inecol 17b & Leminski 18a & Leminski 18b \\
\hline $\mathbf{N}$ & 62 & 75 & 72 & 110 & 143 & 36 & 41 \\
\hline A & 112,814 & 68,414 & 75,306 & 63,408 & 47,669 & 95,713 & 108,817 \\
\hline B & 65,821 & 40,455 & 50,733 & 32,818 & 27,946 & 55,541 & 67,750 \\
\hline $\mathbf{R}$ & 1,714 & 1,691 & 1,484 & 1,932 & 1,706 & 1,723 & 1,606 \\
\hline$\Phi$ & $140,77^{\circ}$ & $41,34^{\circ}$ & $178,38^{\circ}$ & $127,69^{\circ}$ & $145,95^{\circ}$ & $8,73^{\circ}$ & $90,82^{\circ}$ \\
\hline Amostra & Leminski 19a & Leminski 19b & Leminski 19c & S. Jorge 20a & S. Jorge 20b & S. Jorge 21a & S. Jorge 21b \\
\hline $\mathbf{N}$ & 79 & 62 & 60 & 504 & 379 & 285 & 317 \\
\hline A & 45,064 & 35,611 & 27,678 & 45,931 & 52,076 & 33,036 & 31,202 \\
\hline B & 20,235 & 23,901 & 19,734 & 24,639 & 30,550 & 16,609 & 15,903 \\
\hline $\mathbf{R}$ & 2,227 & 1,490 & 1,403 & 1,864 & 1,705 & 1,989 & 1,962 \\
\hline$\Phi$ & $173,53^{\circ}$ & $37,42^{\circ}$ & $141,94^{\circ}$ & $41,80^{\circ}$ & $24,88^{\circ}$ & $83,48^{\circ}$ & $25,55^{\circ}$ \\
\hline Amostra & S. Jorge 22a & S. Jorge 22b & S. Jorge 22c & Anfibolito 23a & Anfibolito 23b & Quartzito 24a & Quartzito 24b \\
\hline $\mathbf{N}$ & 126 & 172 & 144 & 92 & 105 & 116 & 80 \\
\hline A & 47,138 & 44,160 & 42,642 & 84,394 & 58,578 & 1,233 & 1,245 \\
\hline B & 22,991 & 26,130 & 35,048 & 28,525 & 30,926 & 0,612 & 0,624 \\
\hline $\mathbf{R}$ & 2,050 & 1,690 & 1,217 & 2,959 & 1,894 & 2,014 & 1,996 \\
\hline$\Phi$ & $30,74^{\circ}$ & $92,03^{\circ}$ & $15,47^{\circ}$ & $13,90^{\circ}$ & $132,37^{\circ}$ & $122,03^{\circ}$ & $71,51^{\circ}$ \\
\hline Amostra & Xisto 25a & Xisto 25b & Xisto 26a & Xisto 26b & & & \\
\hline $\mathbf{N}$ & 60 & 64 & 62 & 175 & & & \\
\hline A & 3,453 & 1,612 & 1,024 & 1,092 & & & \\
\hline B & 0,693 & 0,628 & 0,429 & 0,556 & & & \\
\hline $\mathbf{R}$ & 4,984 & 2,567 & 2,388 & 1,965 & & & \\
\hline$\Phi$ & $62,02^{\circ}$ & $170,35^{\circ}$ & $25,88^{\circ}$ & $39,08^{\circ}$ & & & \\
\hline
\end{tabular}


Os valores de $\mathrm{R}$ observados para os feldspatos são 2,959 a 1,103 (plano XZ) e 1,894 a 1,035 (plano YZ). Para a foliação Sn-1 os valores da razão de deformação do quartzo foram 3,476 a 3,463 (XZ) e 2,094 a 1,900 (YZ). Os valores de R para os feldspatos foram 2,913 a 1,103 (XZ) e 1,643 a 1,035 (YZ). Para a foliação Sn os valores de $\mathrm{R}$ dos feldspatos foram 2,959 a 1,584 (XZ) e 1,894 a 1,212 (YZ). Os valores de R para o quartzo foram 4,984 a 1,864 (XZ) e 2,567 a 1,217 (YZ).
Os marcadores de quartzo mostram taxas mais altas de $\mathrm{R}$, retratando maior grau de achatamento. Os diagramas do método de Fry para as amostras analisadas podem ser visualizados nas figuras $14 \mathrm{~A}$ e $14 \mathrm{~B}$, cujos resultados mostram um vazio central elíptico, sugerindo a existência de deformação. O número de pontos contíguos ao vazio é alto, havendo, desta forma, baixa probabilidade de erro (Crespi, 1986).

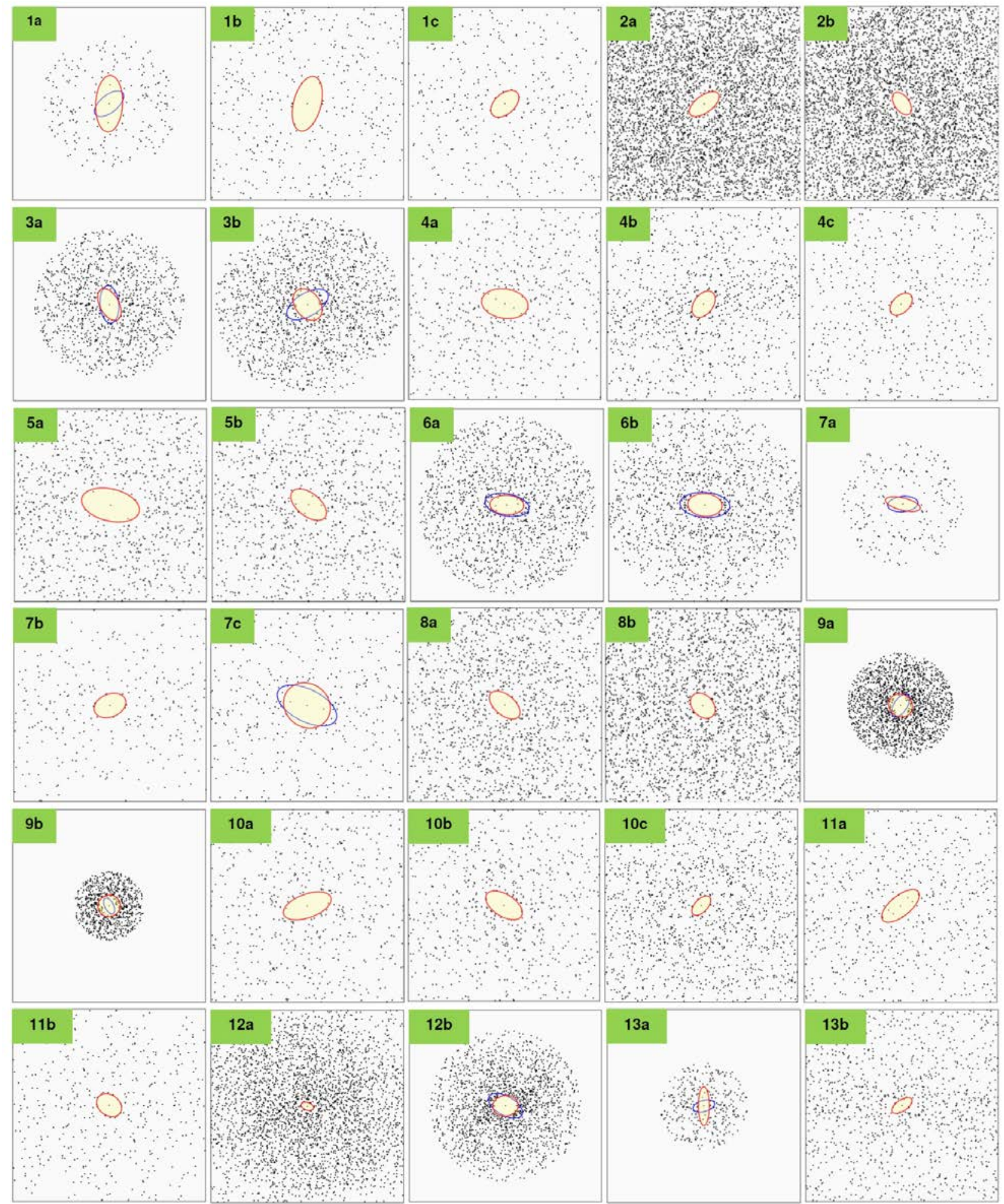

Figura 14A: Método de Fry aplicado às rochas do Complexo Atuba. 


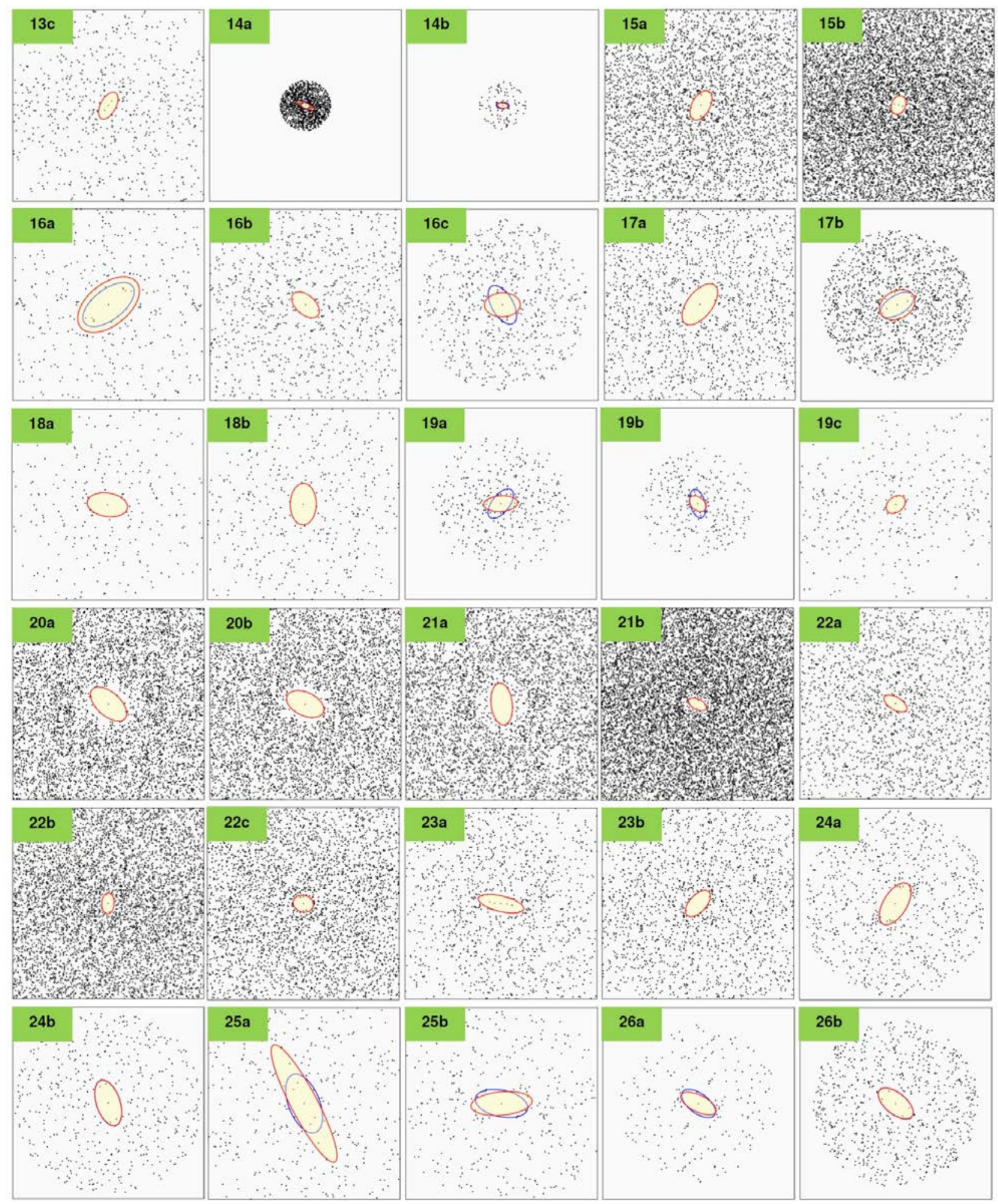

Figura 14B: Método de Fry aplicado às rochas do Complexo Atuba (continuação).

\section{Método Polar}

Os números totais da razão de deformação (R) para o quartzo oscilam entre 2,198 e 1,372 nos planos de cortes XZ e, entre 1,812 e 1,057 nos planos de corte YZ (Tabela 2). Para os feldspatos, os resultados obtidos da razão de deformação $(\mathrm{R})$ total variam entre 1,998 a 1,081 (plano XZ) e 1,627 a 1,007 (plano YZ). Os valores de R para a foliação Sn-1, tendo como marcador o quartzo, variam entre 2,044 e 1,446 (plano XZ) e entre 1,301 e 1,244 (plano YZ). Para os feldspatos os resultados obtidos variam entre 1,693 a 1,081 (plano XZ) e 1,627 a 1,016 (plano YZ). Para a foliação Sn o quartzo teve valores da razão de deformação entre 2,198 a 1,372 (plano XZ) e 1,812 a 1,057. Os feldspatos obtiveram números entre 1,998 a 1,101 (plano XZ) e 1,588 a 1,007 (plano YZ).

Os gráficos do método Polar de Elliott podem ser visualizados nas figuras 15A, 15B E 15C. Na maioria dos diagramas os resultados encontram- 
se pouco dispersos em torno da média, indicada

no corte YZ, sugerindo uma maior confiança na como um círculo vermelho. Observa-se um agrupamento de dados maior no corte $\mathrm{XZ}$ do que média no plano XZ. Os dados foram contornados em $25 \%$ da distribuição de densidade.

Tabela 2: Parâmetros de deformação obtidos pelo método Polar. LEGENDA: N: número de medidas. R: razão da elipse $=\mathrm{a} / \mathrm{b}$. $\phi$ : orientação do maior eixo da elipse.

\begin{tabular}{|c|c|c|c|c|c|c|c|}
\hline Amostra & Artecipe 1a & Artecipe 1b & Artecipe 1c & Artecipe 2a & Artecipe 2b & Artecipe 3a & Artecipe 3b \\
\hline $\mathbf{N}$ & 132 & 124 & 121 & 69 & 84 & 60 & 70 \\
\hline $\mathbf{R}$ & 1,240 & 1,203 & 1,155 & 1,998 & 1,588 & 1,494 & 1,325 \\
\hline$\Phi$ & $41,66^{\circ}$ & $164,03^{\circ}$ & $11,22^{\circ}$ & $106,64^{\circ}$ & $81,28^{\circ}$ & $44,48^{\circ}$ & $19,26^{\circ}$ \\
\hline Amostra & Atuba 4a & Atuba 4b & Atuba 4c & Atuba 5a & Atuba 5b & Atuba 6a & Atuba 6b \\
\hline $\mathbf{N}$ & 121 & 130 & 93 & 73 & 62 & 60 & 60 \\
\hline $\mathbf{R}$ & 1,268 & 1,167 & 1,077 & 1,362 & 1,354 & 1,316 & 1,148 \\
\hline$\Phi$ & $152,63^{\circ}$ & $153,84^{\circ}$ & $38,79^{\circ}$ & $84,26^{\circ}$ & $73,90^{\circ}$ & $152,59^{\circ}$ & $149,07^{\circ}$ \\
\hline Amostra & Central 7a & Central 7b & Central 7c & Central 8a & Central 8b & Central 9a & Central 9b \\
\hline $\mathbf{N}$ & 127 & 132 & 109 & 71 & 77 & 76 & 61 \\
\hline $\mathbf{R}$ & 1,320 & 1,094 & 1,086 & 1,462 & 1,263 & 1,225 & 1,193 \\
\hline$\Phi$ & $177,35^{\circ}$ & $128,50^{\circ}$ & $3,83^{\circ}$ & $74,93^{\circ}$ & $65,38^{\circ}$ & $59,71^{\circ}$ & $70,14^{\circ}$ \\
\hline Amostra & Costa 10a & Costa 10b & Costa 10c & Costa 11a & Costa 11b & Costa 12a & Costa 12b \\
\hline $\mathbf{N}$ & 127 & 114 & 142 & 111 & 123 & 61 & 61 \\
\hline $\mathbf{R}$ & 1,281 & 1,178 & 1,113 & 1,101 & 1,007 & 1,363 & 1,355 \\
\hline$\Phi$ & $3,63^{\circ}$ & $20,17^{\circ}$ & $148,02^{\circ}$ & $179,39^{\circ}$ & $123,44^{\circ}$ & $174,41^{\circ}$ & $163,46^{\circ}$ \\
\hline Amostra & Greca 13a & Greca 13b & Greca 13c & Greca 14a & Greca 14b & Inecol 15a & Inecol 15b \\
\hline $\mathbf{N}$ & 173 & 165 & 111 & 60 & 43 & 63 & 82 \\
\hline $\mathbf{R}$ & 1,446 & 1,263 & 1,244 & 2,044 & 1,301 & 1,693 & 1,627 \\
\hline$\Phi$ & $175,34^{\circ}$ & $9,31^{\circ}$ & $173,97^{\circ}$ & $4,48^{\circ}$ & $140,28^{\circ}$ & $101,11^{\circ}$ & $110,01^{\circ}$ \\
\hline Amostra & Inecol 16a & Inecol 16b & Inecol 16c & Inecol 17a & Inecol 17b & Leminski 18a & Leminski 18b \\
\hline $\mathbf{N}$ & 118 & 154 & 140 & 161 & 211 & 69 & 80 \\
\hline $\mathbf{R}$ & 1,347 & 1,187 & 1,181 & 1,131 & 1,129 & 1,081 & 1,074 \\
\hline$\Phi$ & $4,09^{\circ}$ & $177,18^{\circ}$ & $7,57^{\circ}$ & $13,99^{\circ}$ & $156,56^{\circ}$ & $111,09^{\circ}$ & $140,14^{\circ}$ \\
\hline Amostra & Leminski 19a & Leminski 19b & Leminski 19c & S. Jorge 20a & S. Jorge 20b & S. Jorge 21a & S. Jorge 21b \\
\hline $\mathbf{N}$ & 140 & 112 & 101 & 81 & 61 & 72 & 77 \\
\hline $\mathbf{R}$ & 1,237 & 1,116 & 1,016 & 1,690 & 1,588 & 1,695 & 1,435 \\
\hline$\Phi$ & $1,34^{\circ}$ & $90,88^{\circ}$ & $151,87^{\circ}$ & $63,52^{\circ}$ & $69,35^{\circ}$ & $76,53^{\circ}$ & $62,32^{\circ}$ \\
\hline Amostra & S. Jorge 22a & S. Jorge 22b & S. Jorge 22c & Anfibolito 23a & Anfibolito 23b & Quartzito 24a & Quartzito 24b \\
\hline $\mathbf{N}$ & 211 & 240 & 218 & 156 & 176 & 116 & 80 \\
\hline $\mathbf{R}$ & 1,487 & 1,184 & 1,057 & 1,250 & 1,249 & 1,922 & 1,587 \\
\hline$\Phi$ & $3,34^{\circ}$ & $11,31^{\circ}$ & $176,29^{\circ}$ & $6,24^{\circ}$ & $68,73^{\circ}$ & $144,77^{\circ}$ & $33,35^{\circ}$ \\
\hline Amostra & Xisto 25a & Xisto 25b & Xisto 26a & Xisto 26b & & & \\
\hline $\mathbf{N}$ & 60 & 64 & 62 & 175 & & & \\
\hline $\mathbf{R}$ & 1,372 & 1,264 & 2,198 & 1,812 & & & \\
\hline$\Phi$ & $3,08^{\circ}$ & $11,70^{\circ}$ & $4,09^{\circ}$ & $3,31^{\circ}$ & & & \\
\hline
\end{tabular}

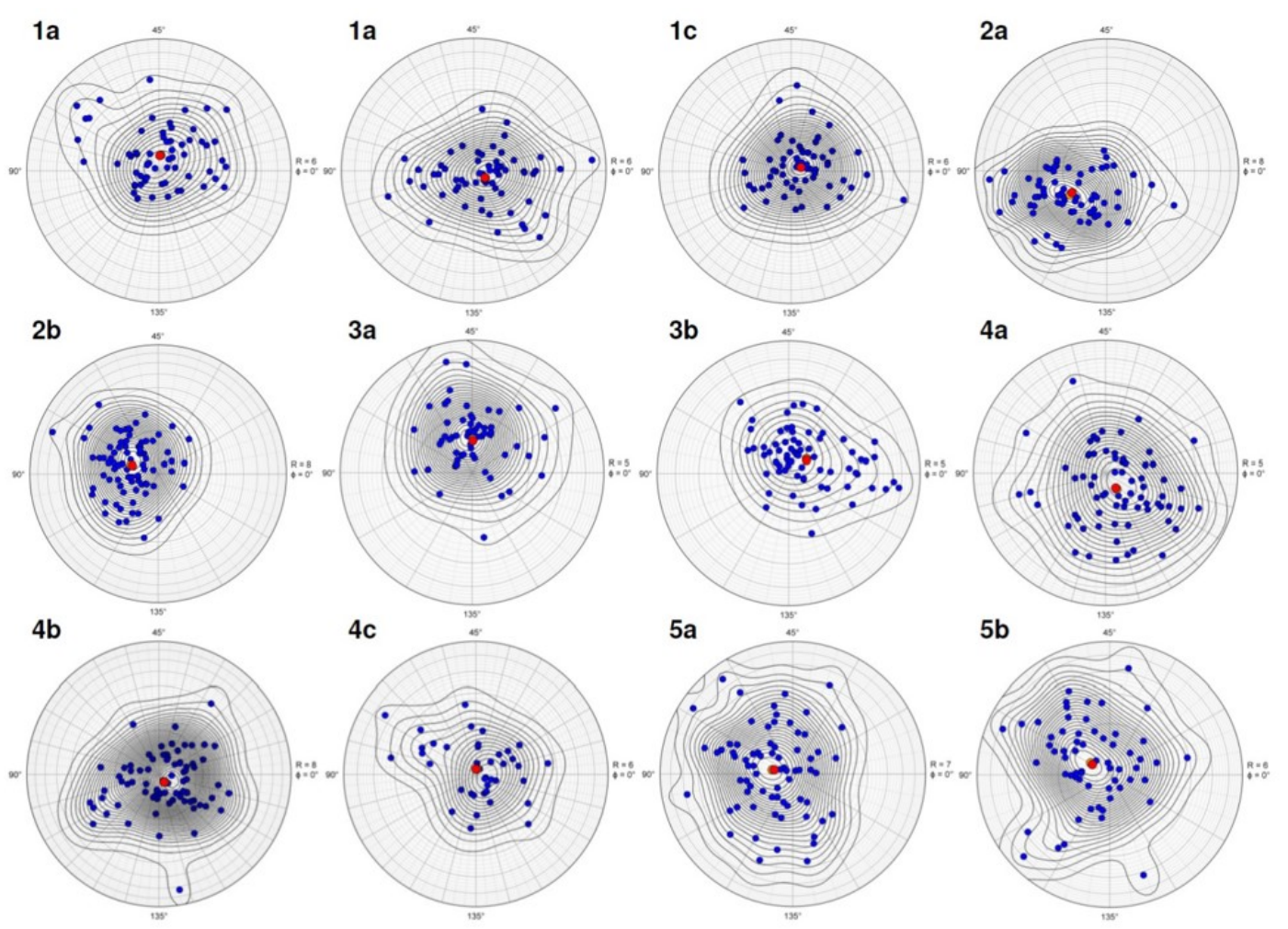

Figura 15A: Método Polar aplicado aos migmatitos, anfibolitos, quartzitos e xistos do Complexo Atuba. 

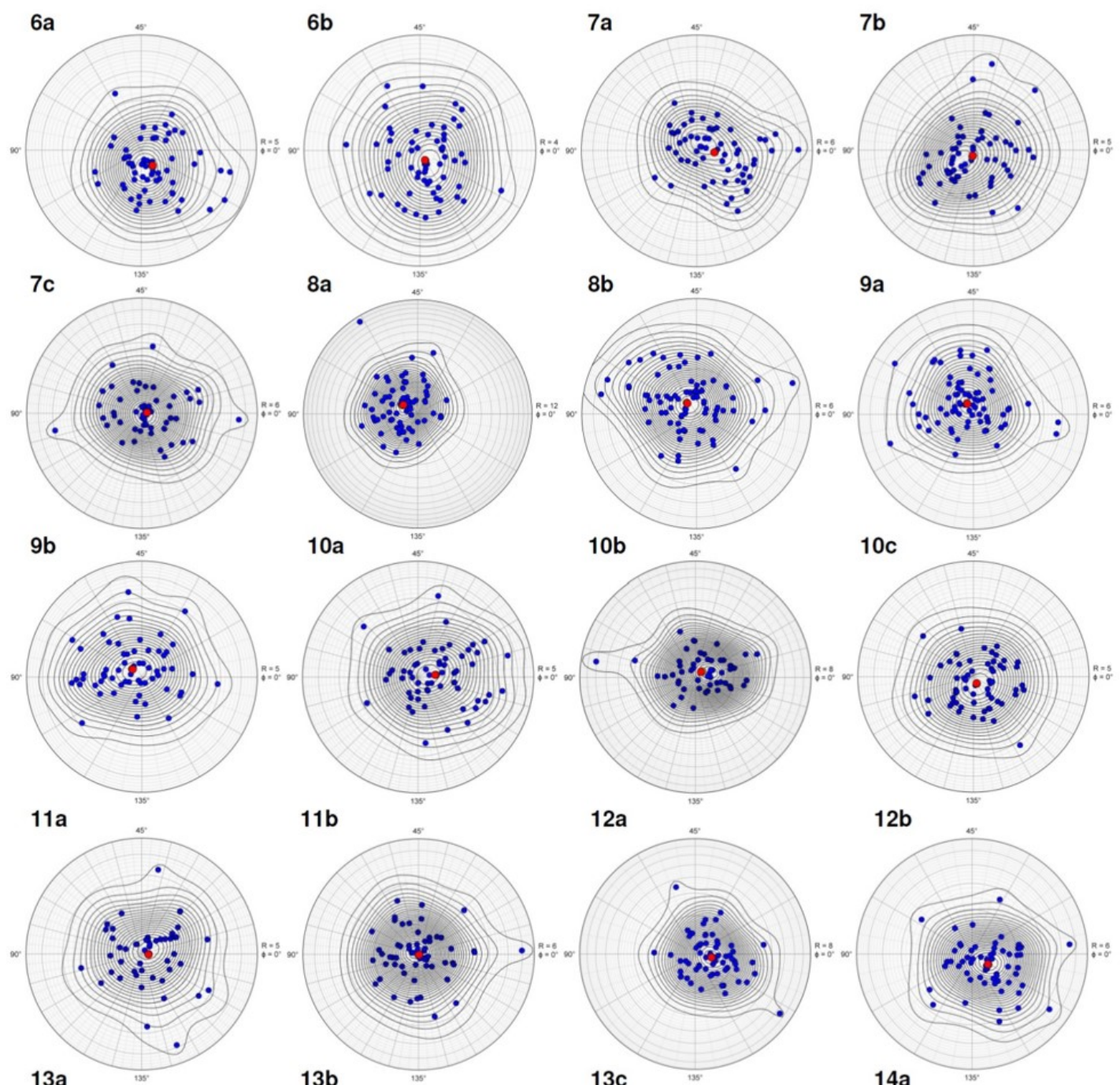

11b
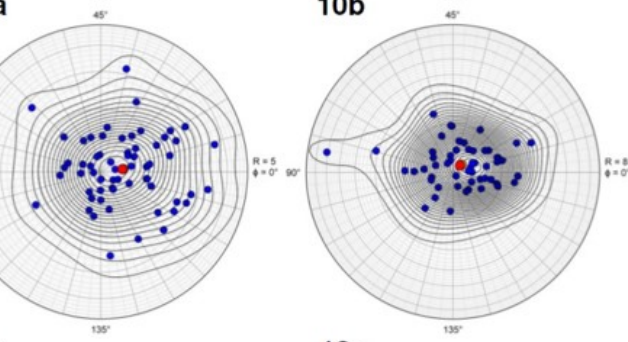

$10 c$

$12 a$

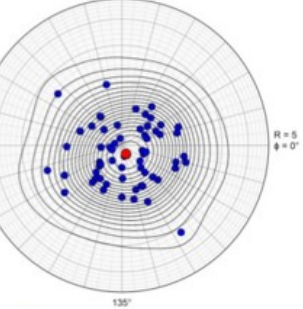

$12 b$
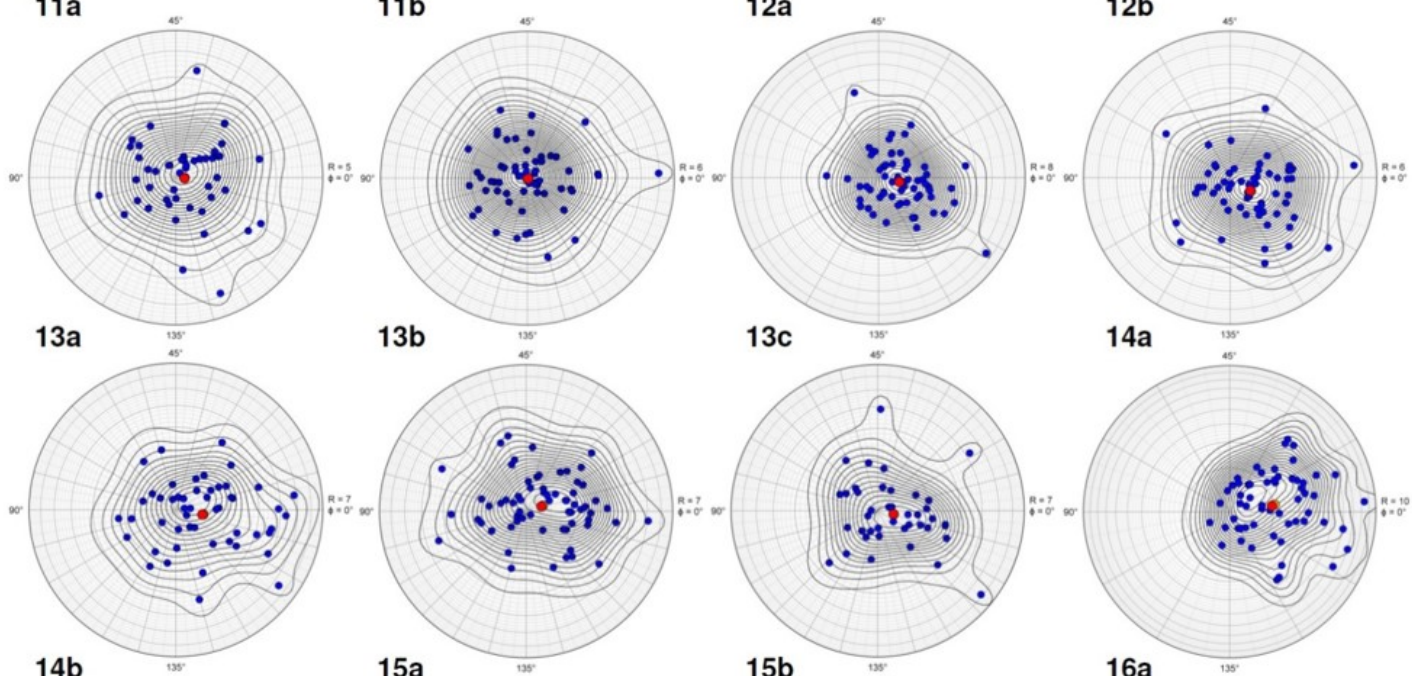

13c 14a
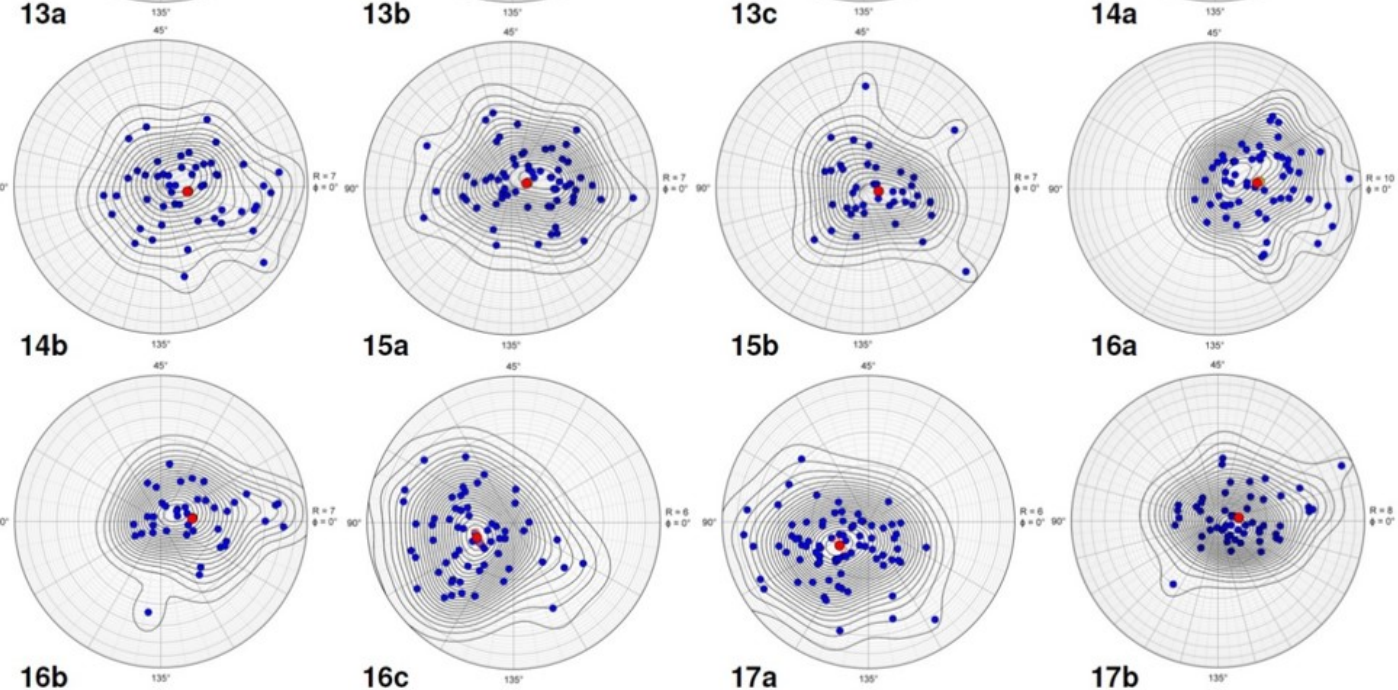

$15 b$

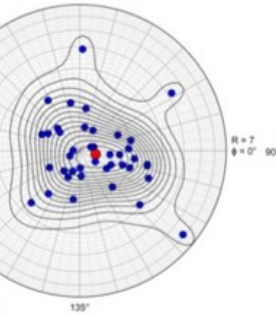

$16 a$
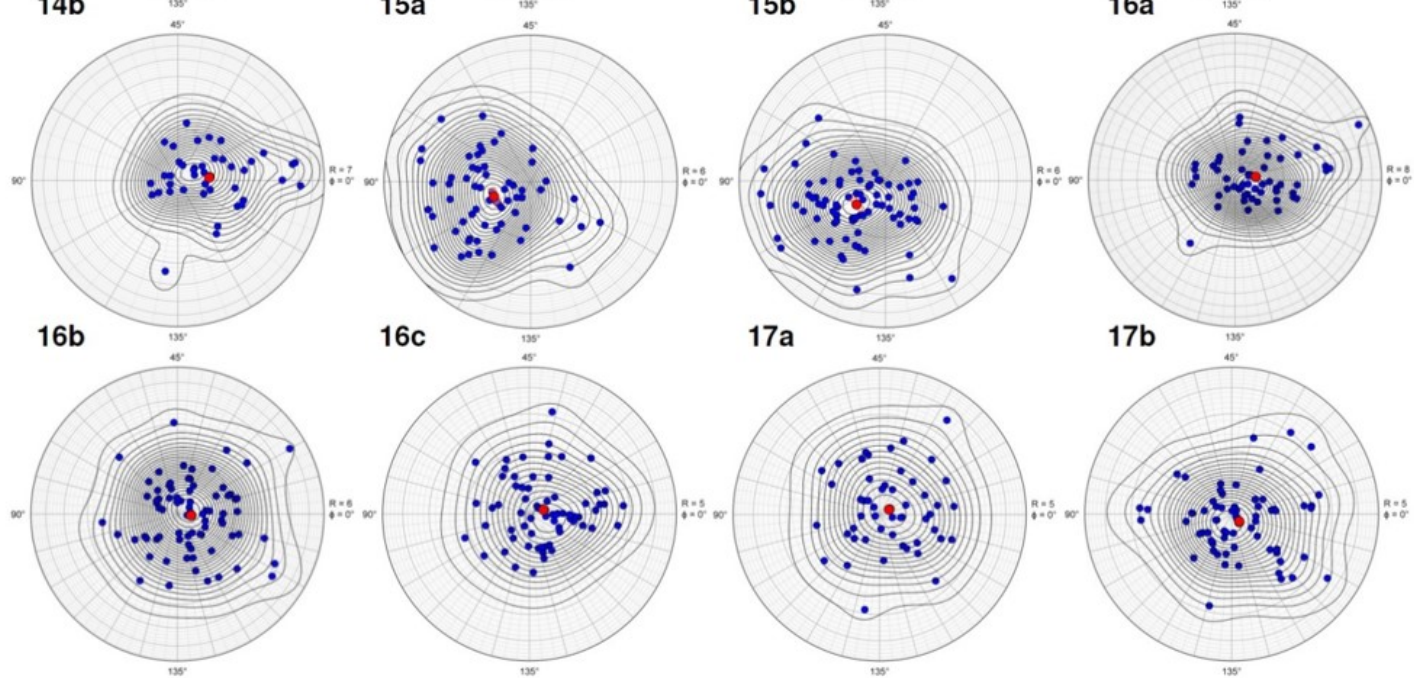

Figura 15B: Método Polar aplicado aos migmatitos, anfibolitos, quartzitos e xistos do Complexo Atuba. (continuação) 


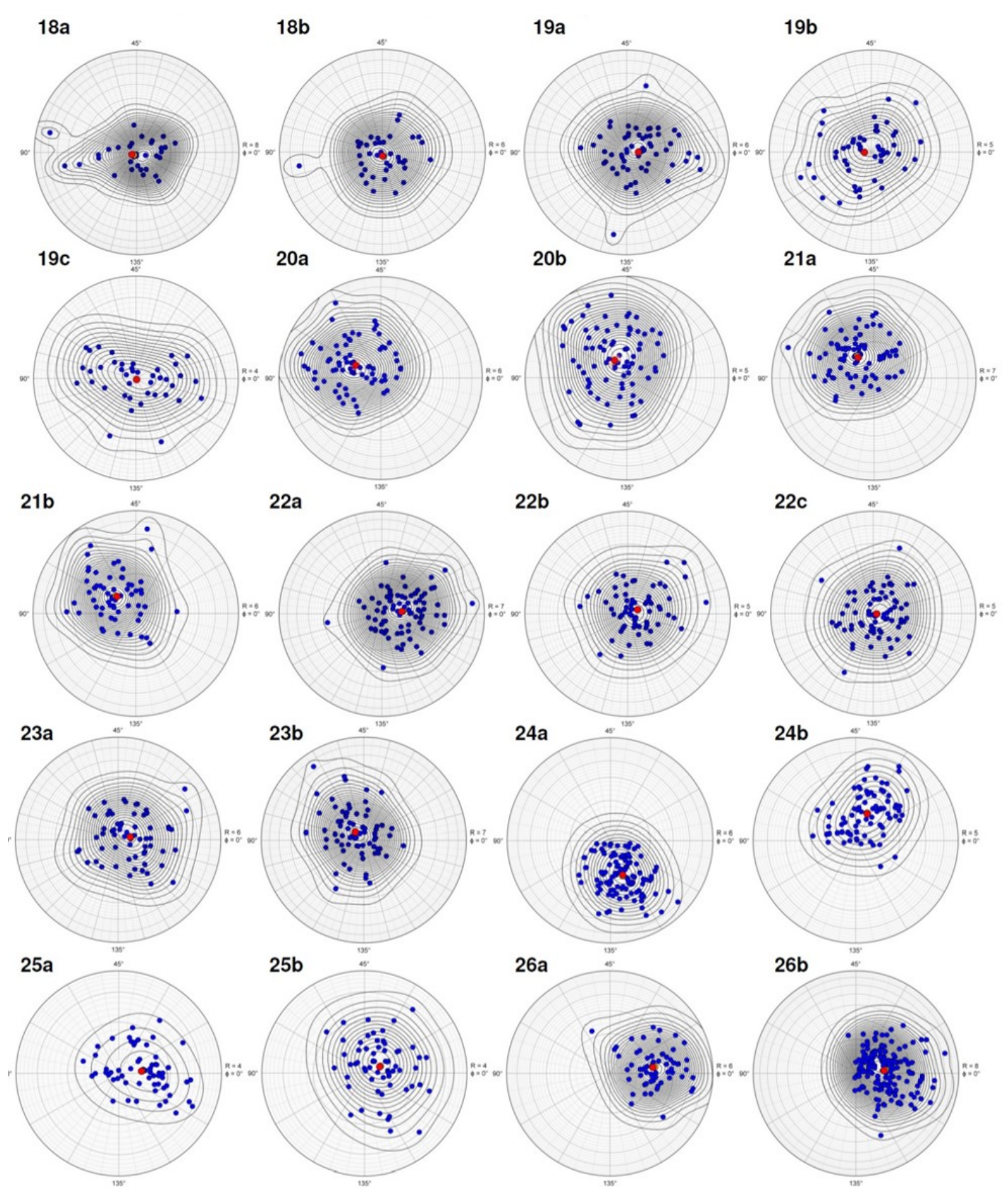

Figura 15C: Método Polar aplicado aos migmatitos, anfibolitos, quartzitos e xistos do Complexo Atuba.

(continuação)

\section{Método $R f / \varphi$}

Os valores do método $\mathrm{Rf} / \varphi$ podem ser visualizados na tabela 3 e os diagramas nas figuras $16 \mathrm{~A}$ e B. As medidas foram contornadas em $25 \%$ de distribuição de densidade e encontram-se moderadamente dispersas em todos os diagramas. Podem refletir alguma concentração em torno da média (círculo vermelho). Os gráficos $\mathrm{Rf} / \varphi$ mostram, no geral, uma distribuição em curva. A concentração dos dados das amostras 2a, 14a, 21a, 22a, 24a, 24b, 26a e 26b se assemelham a uma forma em gota.

Os valores gerais da razão de deformação (R) para os feldspatos variam entre 2,368 a 1,622 nos planos XZ e entre 2,029 a 1,560 nos cortes YZ. Os números de $\mathrm{R}$ para os cristais de quartzo oscilam entre 2,458 a 1,635 (XZ) e entre 2,051 a 1,532 (YZ). A foliação Sn-1 apresenta valores de R para o quartzo entre 2,458 a 2,027 (XZ) e 2,016 a 1,818. Os valores de $\mathrm{R}$ obtidos para os feldspatos estão entre 2,132 a 1,685 (XZ) e 2,005 a 1,560 (YZ). Os cristais de quartzo na foliação Sn apresentam razões de deformação entre 2,390 a 1,635 (XZ) e 2,051 a 1,532 (YZ). Já os feldspatos têm razões que variam de 2,368 a 1,622 (XZ) e de 2,029 a 1,561 (YZ).

$\mathrm{O}$ método $\mathrm{Rf} / \varphi$ apresenta resultados analíticos similares aos do método de Fry e Polar de Elliott. Os valores dos dados (pontos azuis) do método $\mathrm{Rf} / \varphi$ diferem do método Polar principalmente nos valores de $\phi$, porém a média e os dados de R observados nas amostras são praticamente os mesmos. 
Tabela 3: Parâmetros de deformação obtidos pelo método Rf/ $\varphi$. LEGENDA: N: número de medidas. R: razão da elipse $=\mathrm{a} / \mathrm{b}$. $\phi$ : orientação do maior eixo da elipse.

\begin{tabular}{|c|c|c|c|c|c|c|c|}
\hline Amostra & Artecipe 1a & Artecipe 1b & Artecipe 1c & Artecipe 2a & Artecipe 2b & Artecipe 3a & Artecipe 3b \\
\hline $\mathbf{N}$ & 61 & 62 & 61 & 69 & 84 & 60 & 70 \\
\hline $\mathbf{R}$ & 1,769 & 1,753 & 1,599 & 2,368 & 1,965 & 1,794 & 1,707 \\
\hline$\Phi$ & $14,80^{\circ}$ & $169,84^{\circ}$ & $178,59^{\circ}$ & $140,39^{\circ}$ & $13,88^{\circ}$ & $40,60^{\circ}$ & $22,49^{\circ}$ \\
\hline Amostra & Atuba 4a & Atuba 4b & Atuba 4c & Atuba 5a & Atuba 5b & Atuba 6a & Atuba 6b \\
\hline $\mathbf{N}$ & 71 & 80 & 42 & 73 & 62 & 60 & 60 \\
\hline $\mathbf{R}$ & 1,842 & 1,825 & 1,700 & 2,123 & 2,029 & 1,682 & 1,606 \\
\hline$\Phi$ & $167,21^{\circ}$ & $169,39^{\circ}$ & $12,01^{\circ}$ & $11,12^{\circ}$ & $19,57^{\circ}$ & $160,34^{\circ}$ & $172,07^{\circ}$ \\
\hline Amostra & Central 7a & Central 7b & Central 7c & Central 8a & Central 8b & Central 9a & Central 9b \\
\hline $\mathbf{N}$ & 61 & 63 & 54 & 71 & 77 & 76 & 61 \\
\hline $\mathbf{R}$ & 1,772 & 1,645 & 1,614 & 1,908 & 1,836 & 1,708 & 1,692 \\
\hline$\Phi$ & $5,09^{\circ}$ & $162,66^{\circ}$ & $179,50^{\circ}$ & $16,51^{\circ}$ & $24,24^{\circ}$ & $21,96^{\circ}$ & $3,87^{\circ}$ \\
\hline Amostra & Costa 10a & Costa 10b & Costa 10c & Costa 11a & Costa 11b & Costa 12a & Costa 12b \\
\hline $\mathbf{N}$ & 62 & 54 & 62 & 51 & 61 & 61 & 61 \\
\hline $\mathbf{R}$ & 1,710 & 1,690 & 1,561 & 1,622 & 1,602 & 1,751 & 1,732 \\
\hline$\Phi$ & $1,39^{\circ}$ & $13,85^{\circ}$ & $165,84^{\circ}$ & $1,76^{\circ}$ & $2,43^{\circ}$ & $174,74^{\circ}$ & $167,65^{\circ}$ \\
\hline Amostra & Greca 13a & Greca 13b & Greca 13c & Greca 14a & Greca 14b & Inecol 15a & Inecol 15b \\
\hline $\mathbf{N}$ & 51 & 65 & 41 & 60 & 43 & 63 & 82 \\
\hline $\mathbf{R}$ & 2,027 & 1,904 & 1,818 & 2,458 & 2,016 & 2,132 & 2,005 \\
\hline$\Phi$ & $178,15^{\circ}$ & $2,44^{\circ}$ & $178,48^{\circ}$ & $3,15^{\circ}$ & $167,17^{\circ}$ & $155,72^{\circ}$ & $144,63^{\circ}$ \\
\hline Amostra & Inecol 16a & Inecol 16b & Inecol 16c & Inecol 17a & Inecol 17b & Leminski 18a & Leminski 18b \\
\hline $\mathbf{N}$ & 56 & 79 & 68 & 51 & 68 & 33 & 39 \\
\hline $\mathbf{R}$ & 1,774 & 1,737 & 1,633 & 1,692 & 1,664 & 1,698 & 1,560 \\
\hline$\Phi$ & $4,02^{\circ}$ & $2,75^{\circ}$ & $3,54^{\circ}$ & $0,68^{\circ}$ & $175,54^{\circ}$ & $168,89^{\circ}$ & $170,86^{\circ}$ \\
\hline Amostra & Leminski 19a & Leminski 19b & Leminski 19c & S. Jorge 20a & S. Jorge 20b & S. Jorge 21a & S. Jorge 21b \\
\hline $\mathbf{N}$ & 61 & 50 & 41 & 81 & 61 & 72 & 77 \\
\hline $\mathbf{R}$ & 1,685 & 1,680 & 1,594 & 2,025 & 1,911 & 2,013 & 1,899 \\
\hline$\Phi$ & $0,49^{\circ}$ & $1,58^{\circ}$ & $8,86^{\circ}$ & $44,12^{\circ}$ & $39,77^{\circ}$ & $31,74^{\circ}$ & $22,04^{\circ}$ \\
\hline Amostra & S. Jorge 22a & S. Jorge 22b & S. Jorge 22c & Anfibolito 23a & Anfibolito 23b & Quartzito 24a & Quartzito 24b \\
\hline $\mathbf{N}$ & 85 & 68 & 74 & 64 & 71 & 116 & 80 \\
\hline $\mathbf{R}$ & 1,838 & 1,534 & 1,532 & 1,748 & 1,721 & 2,062 & 1,812 \\
\hline$\Phi$ & $1,31^{\circ}$ & $5,70^{\circ}$ & $173,74^{\circ}$ & $6,97^{\circ}$ & $18,75^{\circ}$ & $143,36^{\circ}$ & $29,75^{\circ}$ \\
\hline Amostra & Xisto 25a & Xisto 25b & Xisto 26a & Xisto 26b & & & \\
\hline $\mathbf{N}$ & 60 & 64 & 62 & 175 & & & \\
\hline $\mathbf{R}$ & 1,635 & 1,599 & 2,390 & 2,051 & & & \\
\hline$\Phi$ & $4,07^{\circ}$ & $13,16^{\circ}$ & $5,09^{\circ}$ & $4,71^{\circ}$ & & & \\
\hline
\end{tabular}
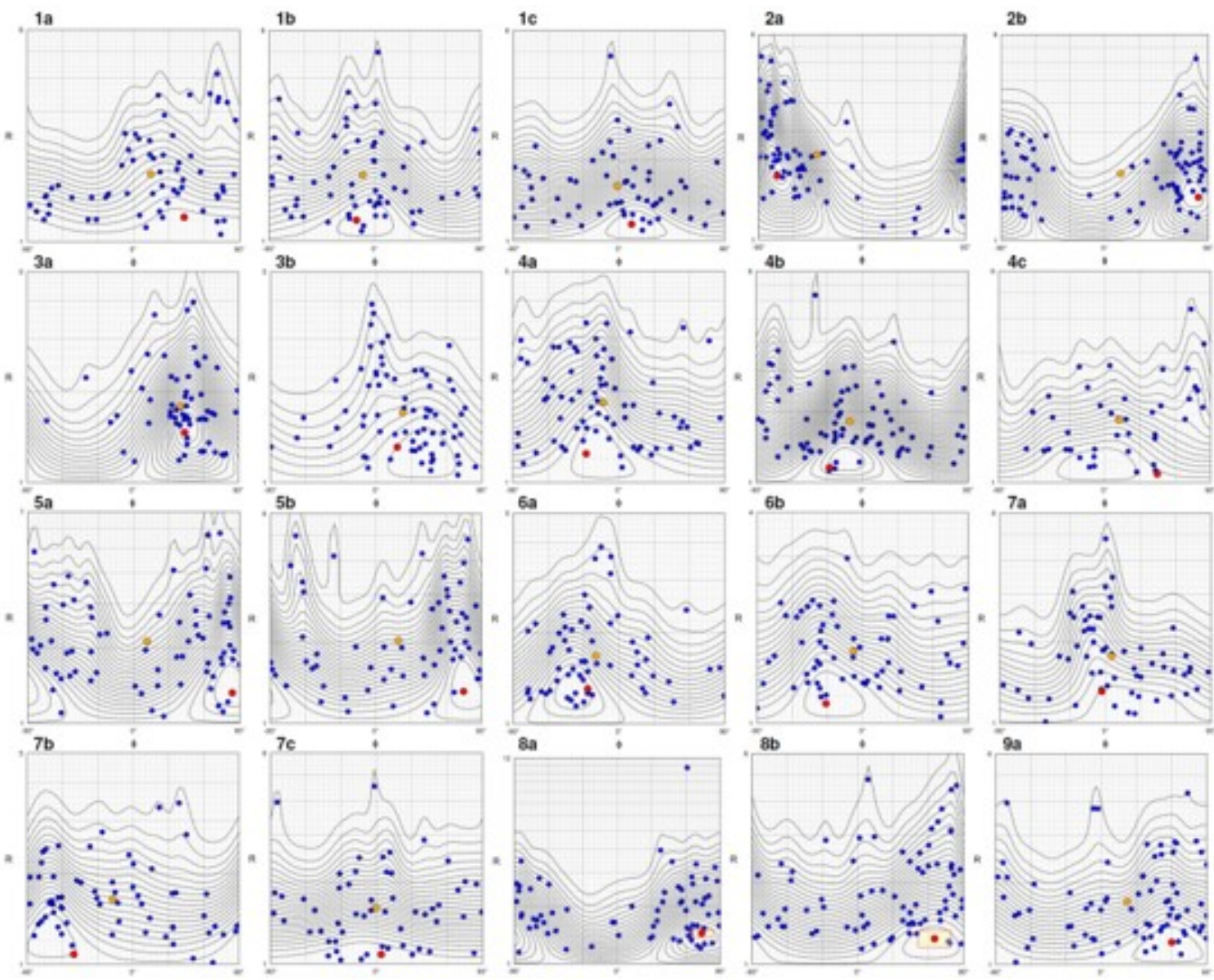

Figura 16A: Método Rf/ $\varphi$ aplicado às rochas do Complexo Atuba, 

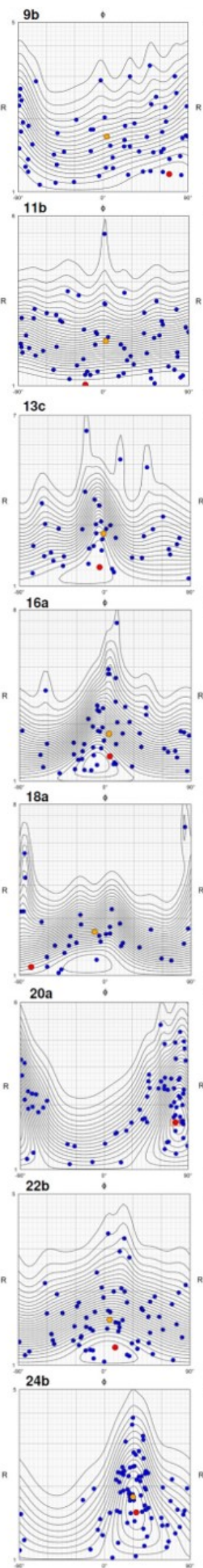
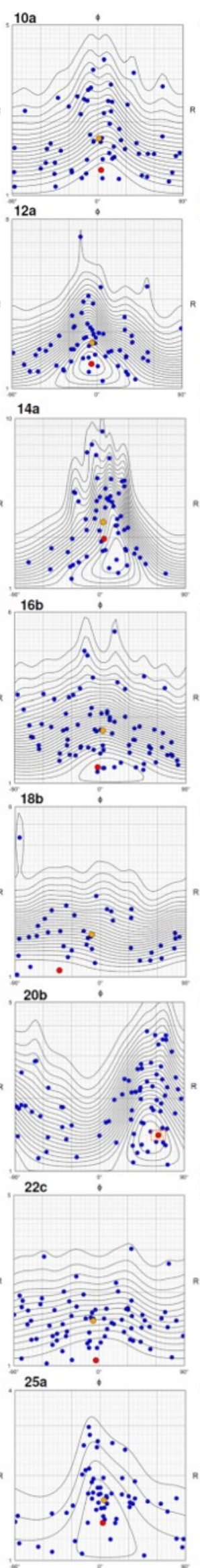
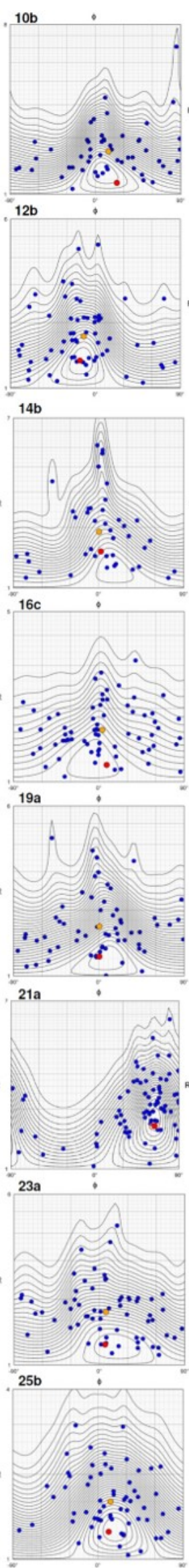
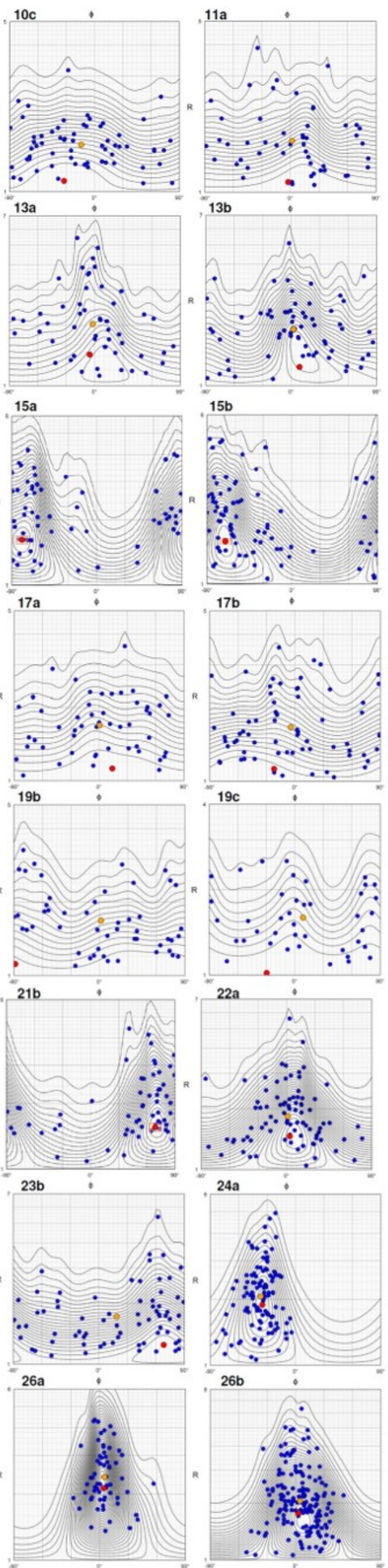

19
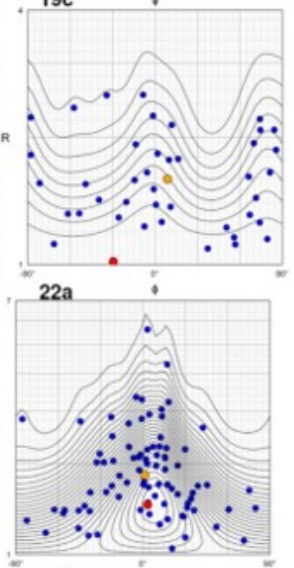

$24 a$

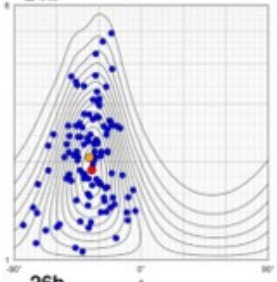

$26 \mathrm{~b}$

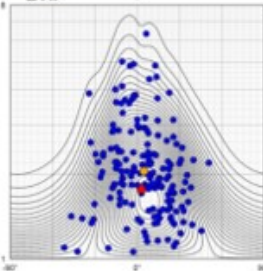

Figura 16B: Método Rf/ $\varphi$ aplicado às rochas do Complexo Atuba (continuação).

plotagens expressam os pontos e elipses

O mapa de deformação exibe os dados como desenhadas nas fotomicrografias analisadas elipses de deformação ou eixos de partículas. As durante o trabalho de análise estrutural (Figuras 
17). Os pontos azuis estão relacionados ao método de Fry e as elipses ao método Polar e $\mathrm{Rf} / \varphi$. As imagens obtidas caracterizam-se por elipses distribuídas em várias direções e sentidos, com predomínio de elipses na direção NW-SE ou NE-SW, tanto nos planos XZ quanto nos planos YZ. O arranjo dos dados é heterogêneo, podendo apresentar menor concentração de pontos e elipses na porção direita das figuras. As elipses podem ser de diversos tamanhos, algumas estando mais circulares do que outras.

\begin{tabular}{|c|c|c|c|c|}
\hline 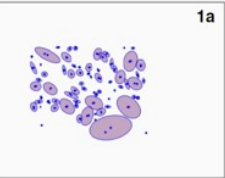 & $\frac{1 \mathrm{~b}}{20 \%}$ & $\frac{50}{0.0 \%}$ & 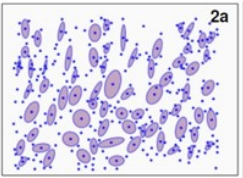 & 4. \\
\hline 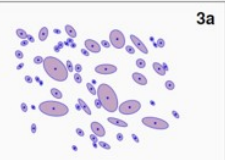 & $\begin{array}{l}\vdots \because 0^{3 b} \\
\because \because 0^{3 b} \\
\because \cdots\end{array}$ & $\frac{8}{20}=2$ & 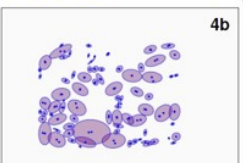 & 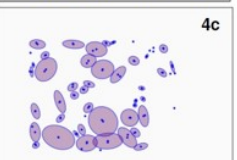 \\
\hline 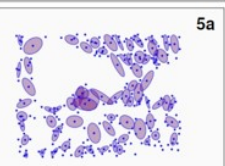 & $60^{5 b}$ & 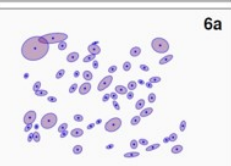 & 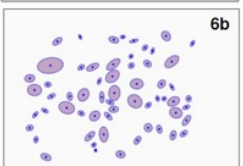 & 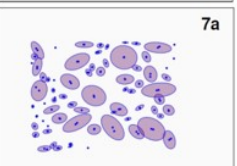 \\
\hline${ }^{7 b}$ & 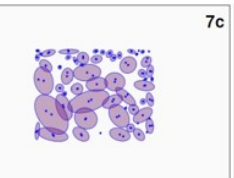 & 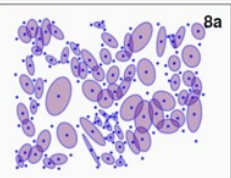 & 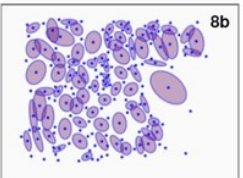 & ${ }^{9 a}$ \\
\hline के? & 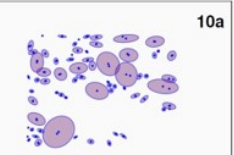 & : & $10 \mathrm{c}$ & ${ }_{3}^{3-30 g}$ \\
\hline$\frac{8^{2}}{80^{11 b}}$ & 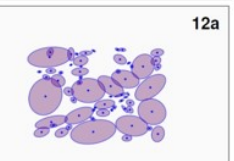 & 12b & $\begin{array}{c}a^{13 a} \\
\vdots \\
0 \\
0\end{array}$ & $\begin{array}{l}:{ }^{13 \mathrm{~b}} \\
\vdots \\
\vdots \\
-\infty\end{array}$ \\
\hline $\begin{array}{c}\because \infty^{13 c} \\
0_{0}\end{array}$ & 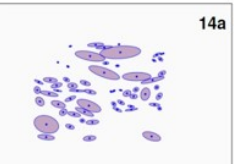 & $\therefore a^{14 \mathrm{~b}}$ & 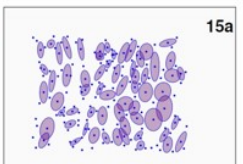 & 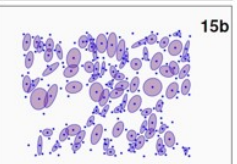 \\
\hline 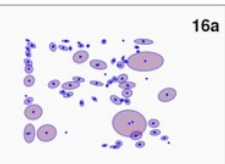 & $\cos ^{16 b}$ & $16 \mathrm{c}$ & $\begin{array}{c}17 a \\
8000 \\
8000\end{array}$ & 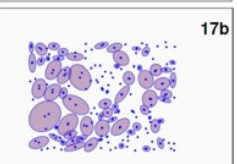 \\
\hline$\frac{300: 0}{80}$ & 18b & 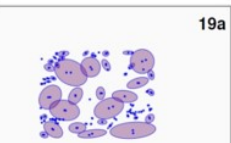 & $8: 0$ & \\
\hline 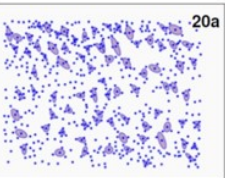 & 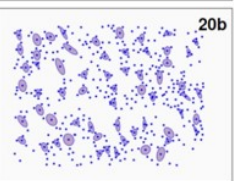 & 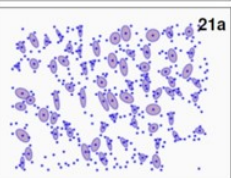 & 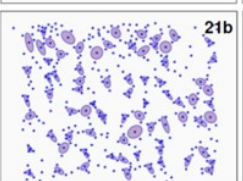 & 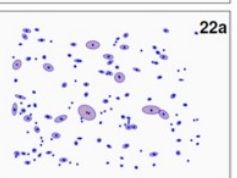 \\
\hline$\therefore a^{22 b}$ & 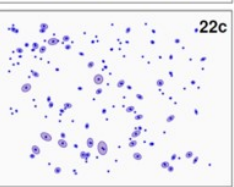 & $\begin{array}{l}23 a \\
\varepsilon_{0}\end{array}$ & $\therefore \cos ^{23 b}$ & 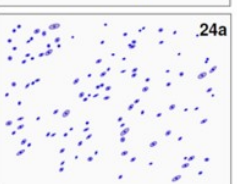 \\
\hline 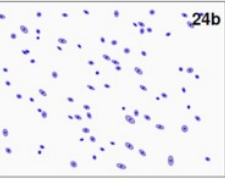 & 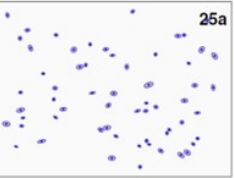 & 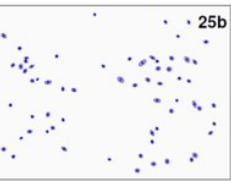 & 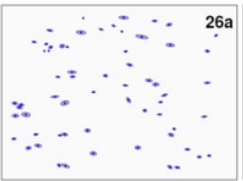 & \begin{tabular}{lll}
$\because$ & $\cdots$ \\
\hdashline & $\ddots 26 \mathrm{~b}$ \\
\hdashline & $\ddots$ & $\ddots$
\end{tabular} \\
\hline
\end{tabular}

Figura 17: Mapas de deformação (strain maps) para as rochas analisadas. 


\section{Diagrama de Flinn e Nadai-Hsü}

O cálculo da deformação, tendo como base o método de Shan (2008), foi desenvolvido com as informações obtidas no método de Fry (Tabela 1). As amostras foram cortadas em três direções e as respectivas atitudes de cada plano incluídas nos cálculos. As amostras utilizadas no processo foram as seguintes: Artecipe (1a, 1b, 1c), Atuba (4a, 4b, 4c), Central (7a, 4b, 7c), Costa (10a, 10b, 10c), Greca (13a, 13b, 13c), Inecol (16a, 16b, 16c), Paulo Leminski (19a, 19b, 19c) e São Jorge (22a, 22b, 22c). A Tabela 4 traz as informações dos cortes e dos eixos (A, B, C), com suas respectivas atitudes.

A inserção dos dados no diagrama de Flinn (Figura 18A) indica que a as amostras analisadas correspondem a elipsoides oblatos, com valores de $K$ muito baixos $(0,25)$ a altos $(0,94)$, posicionando-se no campo do achatamento aparente, o que é compatível com razões de deformação semelhantes obtidas nos planos XZ e YZ. Os tectonitos no diagrama de Flinn podem ser classificados principalmente em S e SL. No diagrama de Nadai-Hsü (Figura 18B), as amostras se posicionam no campo do achatamento aparente $(\varepsilon=0,12 ; v=0,11)$ e da deformação plana $(\varepsilon=0,72 ; v=0,0)$, com geração de elipsoides oblatos. Os tectonitos gerados são S e SL. As linhas radiais do diagrama de Nadai-Hsü indicam quantidades iguais de deformação (Fossen, 2012). As amostras de estudo sugerem quantidades de deformação similares, por se encontrarem muito próximas umas das outras. Os elispsoides de deformação podem ser visualizados na Figura 19.

Tabela 4: Parâmetros obtidos pelo método de Shan (2008).

MÉTODO DE SHAN

\begin{tabular}{|c|c|c|c|}
\hline Pedreiras & Direção e mergulho do plano & Eixos & $\begin{array}{l}\text { Eixos do elipsoide como } \\
\text { lineação de estiramento }\end{array}$ \\
\hline \multirow{3}{*}{ Artecipe (1) } & $330 / 10$ & Máximo (A) - 1,079 & $\begin{array}{c}\text { Direção - 235,79 } \\
\text { Mergulho - 35,46 }\end{array}$ \\
\hline & 131/89 & Intermediário (B) - 1,026 & 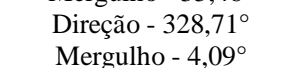 \\
\hline & $351 / 88$ & Mínimo (C) - 0,903 & $\begin{array}{l}\text { Direção - 64,41 } \\
\text { Mergulho - 54,23ㅇ }\end{array}$ \\
\hline \multirow{3}{*}{ Atuba (4) } & $80 / 80$ & Máximo (A) - 1,349 & $\begin{array}{c}\text { Direção -71,58 } \\
\text { Mergulho - } 16,85^{\circ}\end{array}$ \\
\hline & $140 / 89$ & Intermediário (B) - 1,107 & $\begin{array}{l}\text { Direção - 317,70 } \\
\text { Mergulho - 53,19 }\end{array}$ \\
\hline & $230 / 85$ & Mínimo (C) - 0,670 & $\begin{array}{l}\text { Direção - } 172,33^{\circ} \\
\text { Mergulho - } 31,62^{\circ}\end{array}$ \\
\hline \multirow{3}{*}{ Central (7) } & $50 / 45$ & Máximo (A) - 1,092 & $\begin{array}{c}\text { Direção - 26,91 } \\
\text { Mergulho - 43,41 }\end{array}$ \\
\hline & $170 / 50$ & Intermediário (B) - 1,044 & $\begin{array}{l}\text { Direção - } 193,52^{\circ} \\
\text { Mergulho - } 45,80^{\circ}\end{array}$ \\
\hline & $140 / 55$ & Mínimo (C) - 0,877 & $\begin{array}{l}\text { Direção - 290,49} \\
\text { Mergulho - 6,74 }\end{array}$ \\
\hline \multirow{3}{*}{ Costa (10) } & $276 / 20$ & Máximo (A) - 1,643 & $\begin{array}{l}\text { Direção - 76,31 } \\
\text { Mergulho - 8,80 }\end{array}$ \\
\hline & $46 / 84$ & Intermediário (B) - 1,011 & Direção - 332,47 \\
\hline & $141 / 58$ & Mínimo (C) - 0,602 & $\begin{array}{l}\text { Mergulho - 5/,11 } \\
\text { Direção - } 171,73^{\circ} \\
\text { Mergulho - 31,40 }\end{array}$ \\
\hline \multirow{3}{*}{ Greca (13) } & $320 / 70$ & Máximo (A) - 1,575 & $\begin{array}{c}\text { Direção - 55,36 } \\
\text { Mergulho - 26,52 }\end{array}$ \\
\hline & $210 / 80$ & Intermediário (B) - 1,048 & $\begin{array}{l}\text { Direção - } 249,50^{\circ} \\
\text { Mergulho - } 62,77^{\circ}\end{array}$ \\
\hline & $120 / 45$ & Mínimo (C) - 0,606 & $\begin{array}{l}\text { Direção - 148,24ㅇ } \\
\text { Mergulho - 5,74 }\end{array}$ \\
\hline & $270 / 80$ & Máximo (A) - 1,456 & $\begin{array}{l}\text { Direção - 43,24 } \\
\text { Mergulho - 30,09}\end{array}$ \\
\hline Inecol (16) & $10 / 60$ & Intermediário (B) - 1,015 & $\begin{array}{l}\text { Direção - } 145,21^{\circ} \\
\text { Mergulho - } 19,70^{\circ}\end{array}$ \\
\hline & $170 / 85$ & Mínimo (C) - 0,677 & $\begin{array}{l}\text { Direção - 263,40 } \\
\text { Mergulho - 52,83 }\end{array}$ \\
\hline & $270 / 75$ & Máximo (A) - 1,547 & $\begin{array}{l}\text { Direção - 72,55 } \\
\text { Mergulho - 11,37º }\end{array}$ \\
\hline Paulo Leminski (19) & $355 / 60$ & Intermediário (B) - 1,009 & 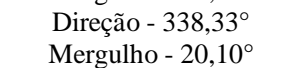 \\
\hline & $120 / 5$ & Mínimo (C) - 0,641 & $\begin{array}{l}\text { Direção - } 190,33^{\circ} \\
\text { Mergulho - 66,66 }\end{array}$ \\
\hline & $10 / 55$ & Máximo (A) - 1,400 & $\begin{array}{c}\text { Direção - 49,74 } \\
\text { Mergulho - } 21,10^{\circ}\end{array}$ \\
\hline São Jorge (22) & $210 / 85$ & Intermediário (B) - 1,069 & $\begin{array}{l}\text { Direção - 250,78 } \\
\text { Mergulho - 67,53ํ }\end{array}$ \\
\hline & $90 / 80$ & Mínimo (C) - 0,669 & $\begin{array}{l}\text { Direção - } 142,59^{\circ} \\
\text { Mergulho - } 7,36^{\circ}\end{array}$ \\
\hline
\end{tabular}



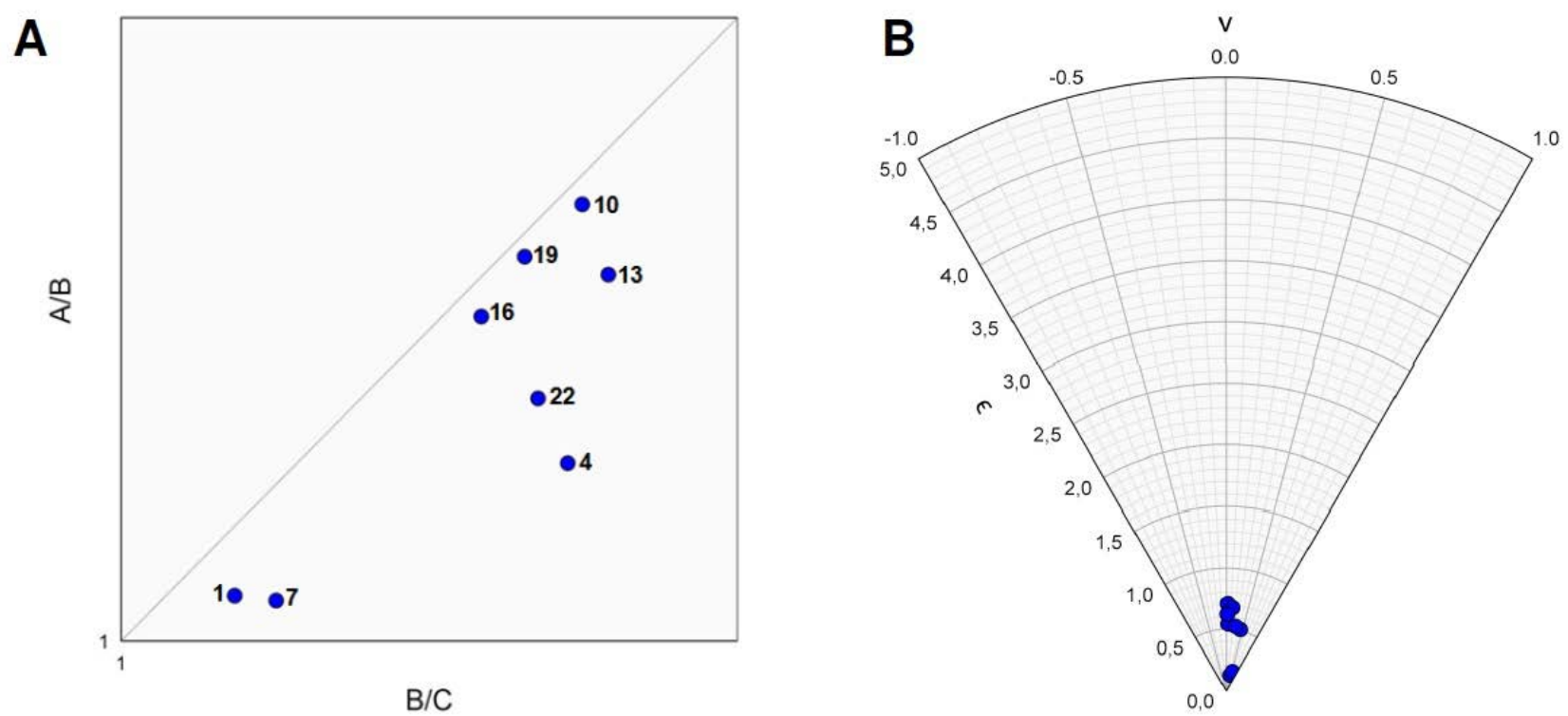

Figura 18: (A) Diagrama de Flinn. (B) Diagrama de Nadai-Hsü. LEGENDA: Artecipe (1), Atuba (4), Central (7), Costa (10), Greca (13), Inecol (16), Paulo Leminski (19) e São Jorge (22).
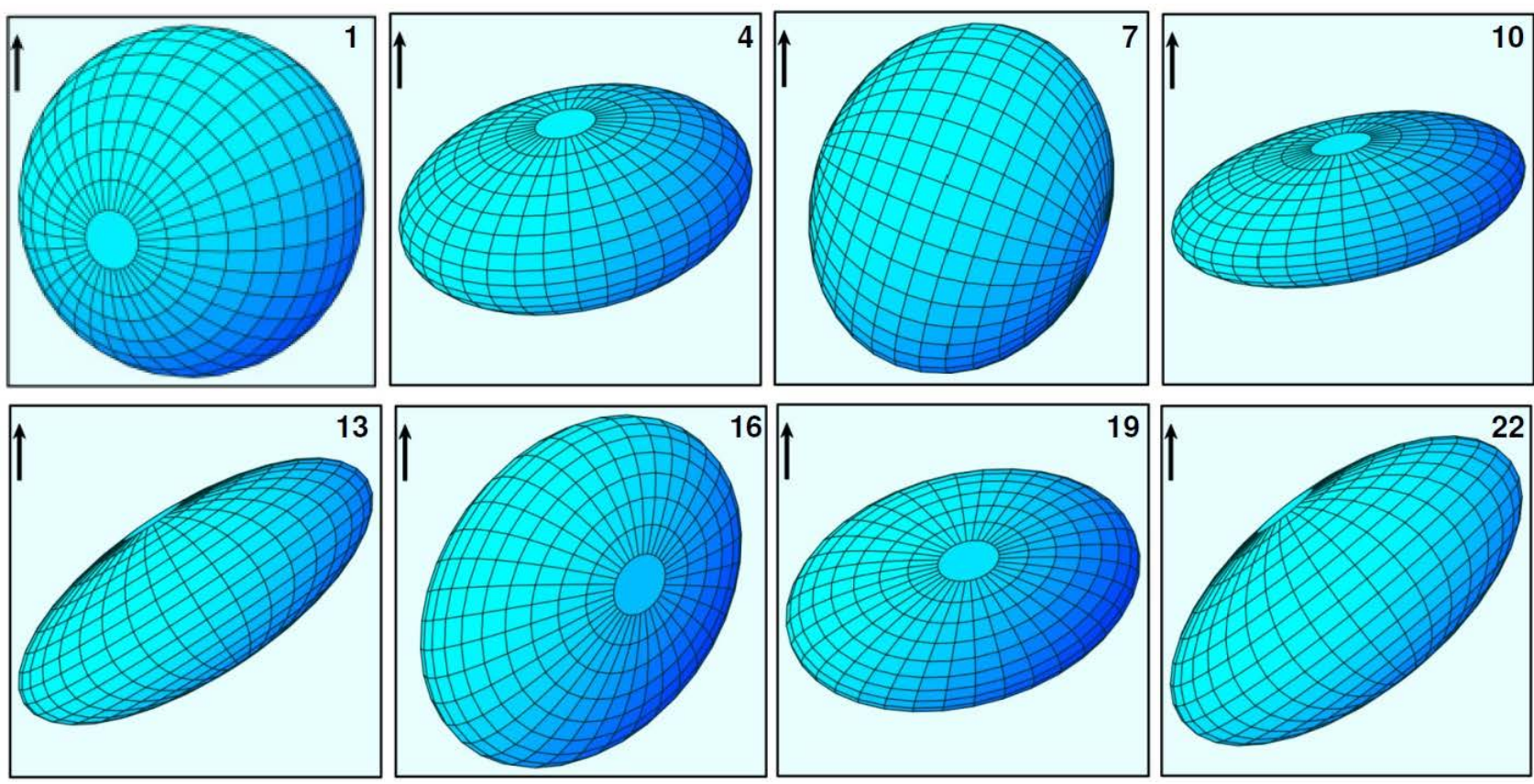

Figura 19: Elipsoides de deformação. Todas as amostras representam elipsoides oblatos. LEGENDA: Artecipe (1), Atuba (4), Central (7), Costa (10), Greca (13), Inecol (16), Paulo Leminski (19) e São Jorge (22). A flecha preta observada em todas as figuras configura o norte.

Nos diagramas de Schmidt os eixos máximos são predominantemente NE, com apenas um eixo para SW. Os eixos intermediários são principalmente para NW e SW e, os eixos mínimos estão orientados para SE e secundariamente para SW (Figura 20).

Para as amostras 2, 3, 5, 6, 8, 9, 11, 12, 14, 15, $17,18,20,21,23,24,25$ e 26 foram utilizados os dados dos métodos de Fry, Polar e Rf/ $\varphi$ para a plotagem dos gráficos de Flinn e Nadai-Hsü (Tabela 5), segundo o método de Hossack (1968). Os resultados no diagrama de Flinn sugerem que a maioria das amostras correspondem a elipsoides oblatos, posicionando-se no campo do achatamento aparente. Os tectonitos podem ser classificados em S e SL (Figuras 21A; 21C; 21E). Apenas as amostras 11 e 12 (Figura 21A) e 11 e 14 (Figura 21C) possuem valor maior do que 1 e plotam no campo da constrição aparente, definindo elipsoides prolatos. Nesse caso, as rochas encontram-se no espaço dos tectonitos LS. As amostras têm magnitude entre 1 a 3 (Figura 21A) e valores entre 1 a 2 (Figuras 21C e 21E).

Nos diagramas de Nadai-Hsü (Figuras 21B; 21D; 21F) as amostras encontram-se predominantemente no campo do achatamento aparente $(\mathrm{K}<1)$, com geração de elipsoides 
oblatos e tectonitos do tipo S e SL, já que os componentes estão fortemente achatados. Do mesmo caso que os diagramas de Flinn, os diagramas de Hsü apresentam quatro amostras
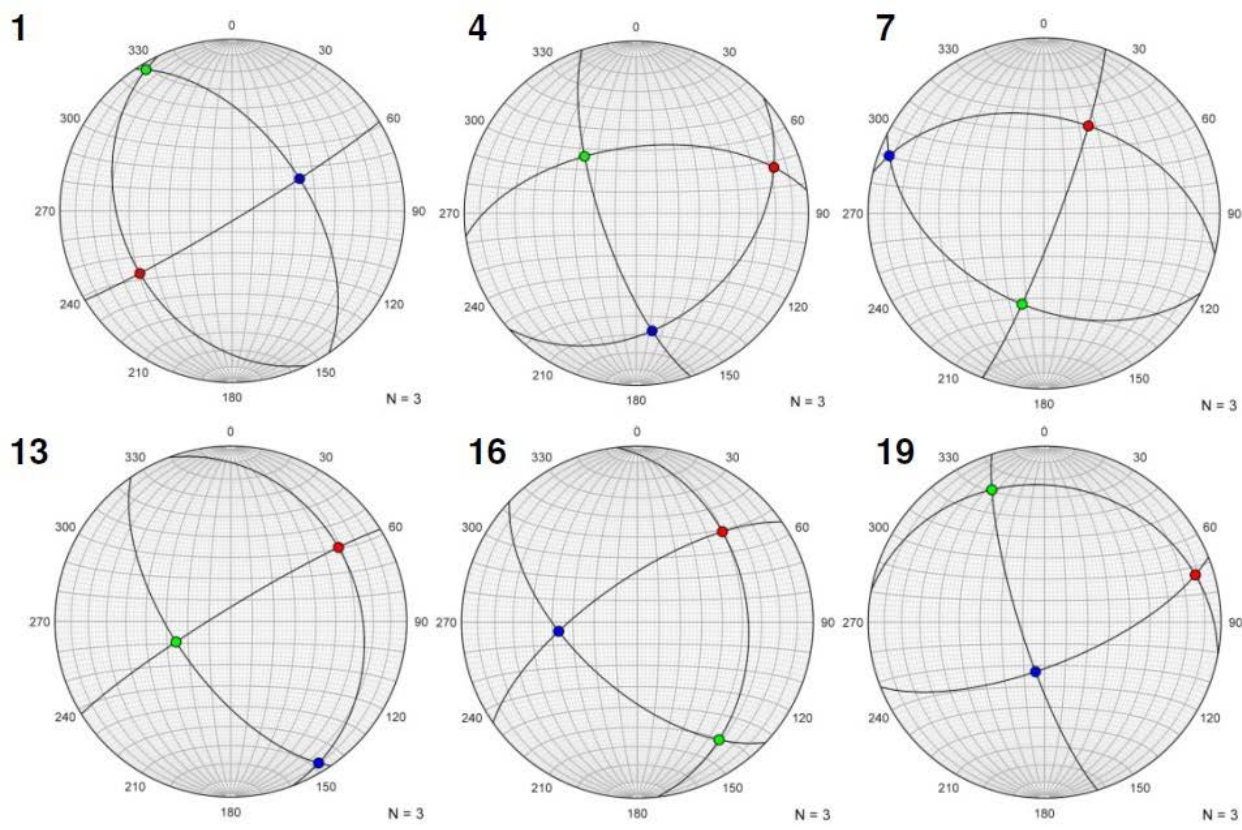

(Figuras 21B; 21D) com constrição geral e formação de elipsoides prolatos. Nesse caso, há tectonitos do tipo LS, pois o alongamento é mais pronunciado do que o achatamento.

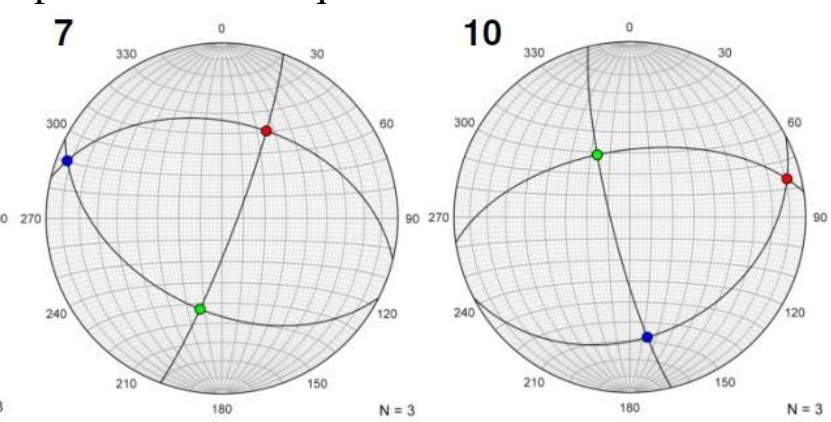

Figura 20: Diagramas de Schmidt (hemisfério inferior) dos eixos dos elipsoides de deformação. Cada diagrama contém $\mathrm{N}=3$. Vermelho $=\mathrm{X}$, verde $=\mathrm{Y}$, azul = Z. LEGENDA: Artecipe (1), Atuba (4), Central (7), Costa (10), Greca (13), Inecol (16), Paulo Leminski (19) e São Jorge (22).

Tabela 5: Parâmetros de deformação utilizados para construção dos diagramas de Flinn e Hsü. As letras A, B e C representam os eixos dos elipsoides e a letra $\mathrm{N}$ reflete o número da amostra.

\begin{tabular}{c|ccc|ccc|ccc}
\hline & \multicolumn{3}{|c}{ MÉTODO DE FRY } & \multicolumn{2}{|c|}{ MÉTODO POLAR } & \multicolumn{3}{|c}{ MÉTODO Rf/ } \\
\hline $\mathbf{N}$ & A & B & C & A & B & C & A & B & C \\
\hline $\mathbf{2}$ & 2,052 & 1,748 & 1 & 1,998 & 1,588 & 1 & 2,368 & 1,965 & 1 \\
$\mathbf{3}$ & 1,814 & 1,441 & 1 & 1,494 & 1,325 & 1 & 1,794 & 1,707 & 1 \\
$\mathbf{5}$ & 1,838 & 1,809 & 1 & 1,362 & 1,354 & 1 & 2,123 & 2,029 & 1 \\
$\mathbf{6}$ & 1,77 & 1,517 & 1 & 1,316 & 1,148 & 1 & 1,682 & 1,606 & 1 \\
$\mathbf{8}$ & 1,79 & 1,377 & 1 & 1,462 & 1,263 & 1 & 1,908 & 1,836 & 1 \\
$\mathbf{9}$ & 1,103 & 1,035 & 1 & 1,225 & 1,193 & 1 & 1,708 & 1,692 & 1 \\
$\mathbf{1 1}$ & 2,223 & 1,317 & 1 & 1,101 & 1,007 & 1 & 1,622 & 1,602 & 1 \\
$\mathbf{1 2}$ & 1,728 & 1,212 & 1 & 1,363 & 1,355 & 1 & 1,751 & 1,732 & 1 \\
$\mathbf{1 4}$ & 3,463 & 2,094 & 1 & 2,044 & 1,301 & 1 & 2,458 & 2,016 & 1 \\
$\mathbf{1 5}$ & 1,774 & 1,367 & 1 & 1,693 & 1,627 & 1 & 2,132 & 2,005 & 1 \\
$\mathbf{1 7}$ & 1,932 & 1,706 & 1 & 1,131 & 1,129 & 1 & 1,692 & 1,664 & 1 \\
$\mathbf{1 8}$ & 1,723 & 1,606 & 1 & 1,081 & 1,074 & 1 & 1,698 & 1,56 & 1 \\
$\mathbf{2 0}$ & 1,864 & 1,705 & 1 & 1,69 & 1,588 & 1 & 2,025 & 1,911 & 1 \\
$\mathbf{2 1}$ & 1,989 & 1,962 & 1 & 1,695 & 1,435 & 1 & 2,013 & 1,899 & 1 \\
$\mathbf{2 3}$ & 2,959 & 1,894 & 1 & 1,25 & 1,249 & 1 & 1,748 & 1,721 & 1 \\
$\mathbf{2 4}$ & 2,014 & 1,996 & 1 & 1,922 & 1,587 & 1 & 2,062 & 1,812 & 1 \\
$\mathbf{2 5}$ & 4,984 & 2,567 & 1 & 1,372 & 1,264 & 1 & 1,635 & 1,599 & 1 \\
$\mathbf{2 6}$ & 2,388 & 1,965 & 1 & 2,198 & 1,812 & 1 & 2,39 & 2,051 & 1 \\
\hline
\end{tabular}



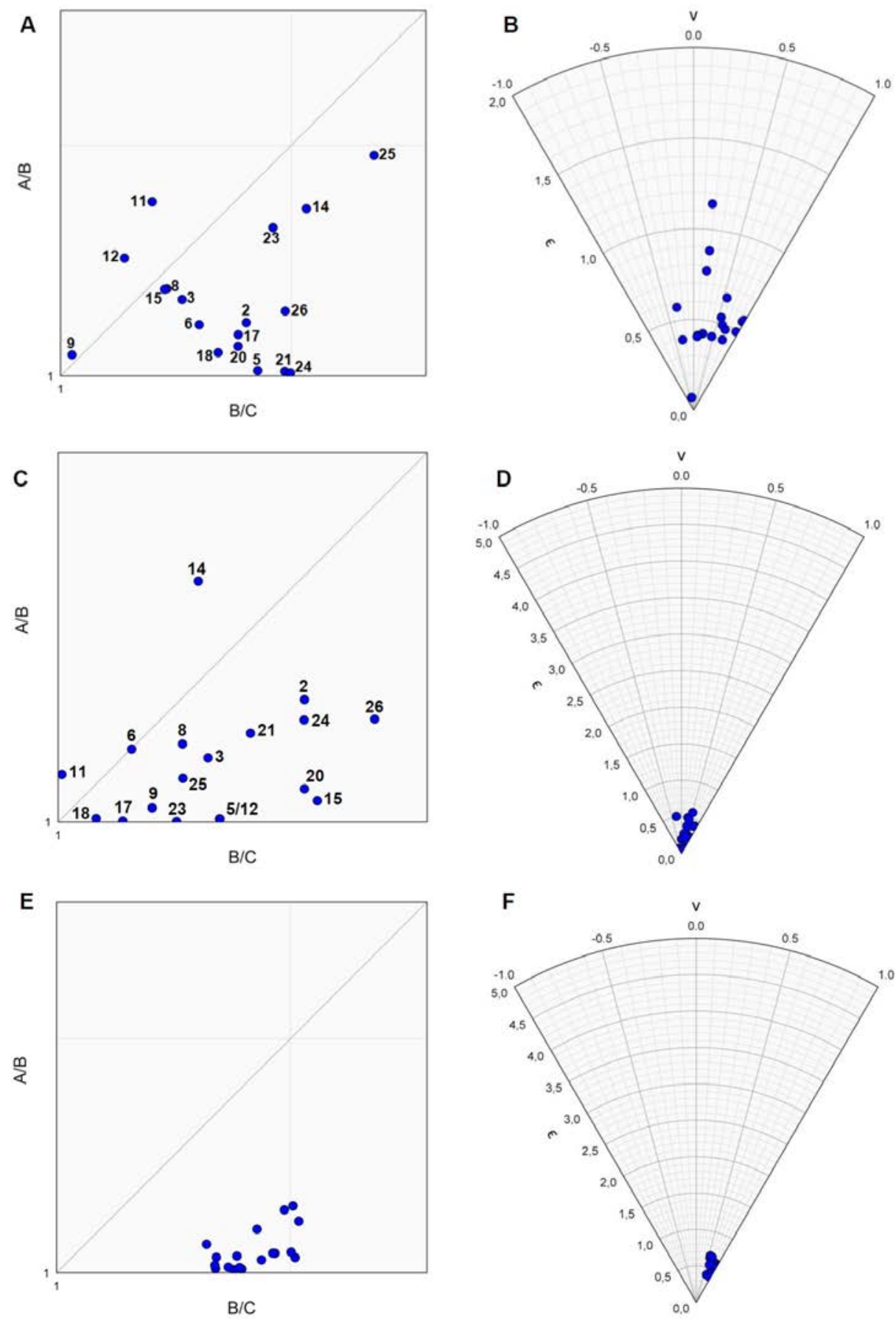

Figura 21: Dados provenientes do método de Fry: (A) Diagrama de Flinn. (B) Diagrama de Nadai-Hsü. Dados provenientes do método Polar: (C) Diagrama de Flinn. (D) Diagrama de Nadai-Hsü. Dados provenientes do método Rf/ $\varphi$ : (E) Diagrama de Flinn. (F) Diagrama de Nadai-Hsü.

\section{DISCUSSÕES}

A área de estudo constitui-se principalmente por migmatitos metatexitos estromáticos, anfibolitos, quartzitos e xistos. As foliações observadas não exibem distribuição homogênea em termos de atitude, variando a direção e o mergulho. Os elementos estruturais dúcteis foram divididos em duas superfícies de deformação (Sn-1 e Sn), com base nas orientações encontradas e relações de corte. As trajetórias de foliação podem ser observadas na Figura 5.
Existem no mínimo três modelos propostos para explicar a evolução da região. Um deles diz respeito ao regime transpressivo (Ebert et al., 1991; 1993; Hackspacher et al., 1992; Correa Neto et al., 1993; Fassbinder, 1996; Dehler, 2007), outro relaciona-se com a superimposição de duas fases deformacionais (tangencial e transcorrente) descritas por Hasui (1983) e Fiori (1990) e, por último, a caracterização feita por Faleiros et al. (2011; 2016), onde apresentaram seis deformações sobrepostas (D1-D6). 
De acordo com o presente trabalho o Complexo Atuba foi submetido a duas fases de migmatização. A primeira fase compreende um leucossoma branco, granodiorítico a tonalítico, foliado e paralelo à foliação principal, gerada entre 2200 e $2100 \mathrm{Ma}$ (U-Pb em zircão, Siga Junior et al., 1995; Sato et al., 2003). Ocorre associada ao metamorfismo de fácies anfibolito superior a granulito (Faleiros, 2008). Essas idades podem ser observadas em gnaisses granulíticos e gnaisses com leucossomas tonalíticos. $\mathrm{Na}$ área de trabalho essas rochas ocorrem principalmente nas pedreiras Paulo Leminski, Central, Artecipe e Inecol. A foliação Sn-1, atribuída à fase Dn-1, está relacionada à primeira fase de migmatização. Possui caráter tangencial dúctil e baixo a alto ângulo de mergulho para NE ou SW, predominando os valores médios. O plano máximo mais representativo obtido em estereograma estrutural é N45W/55NE. Esta superfície está relacionada às lineações de estiramento mineral (quartzo, feldspatos e minerais micáceos orientados) com baixo a médio mergulho principalmente para NE ou SE. Foi dobrada e verticalizada por fases posteriores, atribuídas à estruturação do Cinturão Ribeira, chegando a ficar paralelizada às estruturas mais jovens. Nesse caso, a foliação Sn1 descrita na área de trabalho passaria a apresentar alto ângulo de mergulho com lineação mineral demarcando movimentos direcionais, na evolução da deformação provocada pela Zona de Cisalhamento Lancinha-Cubatão. O padrão francamente noroeste observado nas rochas granulíticas do Terreno Luís Alves é similar à foliação Sn-1 descrita nas rochas do Complexo Atuba (Terreno Curitiba), o que poderia indicar sua correlação com o Terreno Luís Alves. Siga Junior et al. (1993) sugeriram que os gnaisses do Terreno Curitiba derivaram do Terreno Luís Alves devido a razões de evolução ${ }^{87} \mathrm{Sr} /{ }^{86} \mathrm{Sr}$ ao longo do tempo geológico. Segundo os mesmos autores o Terreno Curitiba poderia representar a margem retrabalhada do Terreno Luís Alves no Neoproterozoico. Salamuni (1998) descreveu a foliação Sn-1 no Complexo Atuba como uma superfície secundária, de caráter pretérito, milonítica e transposta pela foliação Sn. O autor também propõe que a estrutura pode ter sido originada em situações de tectônica tangencial, com planos orientados para $\mathrm{N} 35^{\circ}-50^{\circ} \mathrm{W}$ e mergulhos entre $25^{\circ}$ e $40^{\circ}$ para NE ou SW. De acordo com Gonçalves (2012) a foliação Sn-1 no
Complexo Atuba é pouco preservada, planar, levemente anastomosada ou crenulada pela superfície Sn, com atitude principal N10W/79SW.

A segunda fase de migmatização constitui leucossomas médios, rosas e brancos, graníticos, pouco foliados ou maciços. Está associada ao metamorfismo de fácies anfibolito no Neoproterozoico (560-600 Ma, U-Pb SHRIMP em zircão, Sato et al., 2003). A foliação (Sn) na região de pesquisa está associada a esta segunda fase de migmatização. Possui orientação NESW, com mergulhos baixos a altos para NW ou SE. Pode seccionar e transpor a foliação tangencial (Sn-1), cuja relação de corte foi observada principalmente na pedreira Artecipe. A lineação de estiramento mineral possui direção principal NE-SW. A cinemática encontrada na área é sinistral, portanto diferente do caráter dextral observado para a Zona de Cisalhamento Lancinha-Cubatão. Este fato pode ser interpretado como irregularidades na zona de cisalhamento ou como um primeiro pulso dúctil, transcorrente e sinistral da Falha da Lancinha, como observado por Fassbinder (1990), antes do pulso rúptil e dextral. De acordo com Passarelli et al. (2011) zonas de cisalhamento sinistrais secundárias foram geradas, caracterizando o escape tectônico a fim de acomodar a compressão contínua. Os domínios representados pela fase Dn ocorrem em toda a área, com distribuição heterogênea. Aqui são interpretados como uma fase transcorrentetranspressiva (Dn), ligada aos processos orogenéticos finais do Cinturão Ribeira. As principais zonas de cisalhamento na área de pesquisa são formadas pela Zona de Cisalhamento Curitiba e pela Zona de Cisalhamento Lancinha-Cubatão. A Zona de Cisalhamento Curitiba representa uma feição de direção N40-60E e coloca em contato o Grupo Açungui com o Complexo Atuba. Caracteriza-se por uma superposição de estruturas rúpteis e dúcteis com mergulhos altos (Gonçalves, 2012; Cabrita, 2015). Está relacionada à estruturação do Sistema de Transcorrência Lancinha (Fiori, 1985). A Zona de Cisalhamento Lancinha-Cubatão é o principal segmento de um sistema de cisalhamento dextral no sudeste do Brasil (Sadowski, 1991), e está posicionada no limite noroeste da área pesquisada com direção NE-SW.

Para Fuck et al. (1967) a xistosidade e o bandamento dos migmatitos e rochas metamór- 
ficas associadas ao Complexo Atuba estão orientados entre N10E e E-W, com mergulhos sempre próximos da vertical. Os autores não nomearam fases ou eventos deformacionais distintos, mas provavelmente a foliação descrita por eles estejam correlacionada à foliação Sn caracterizada no presente trabalho. Segundo Fiori (1992) as rochas do Grupo Açungui estão afetadas por zonas de cisalhamento NE-SW, com transporte relativo para SE. Siga Junior (1995) e Siga Junior et al. (1995) verificaram uma orientação predominantemente nordeste da superfície Sn dos migmatitos do Complexo Atuba. Essa foliação é paralela ao bandamento e corresponde a uma estrutura de transposição. As lineações de estiramento distribuem-se no quadrante NE, com mergulhos baixos. Siga Junior et al. (1995) associaram o desenvolvimento da foliação Sn com o padrão estrutural retratado por Fiori (1990; 1992) na região de Rio Branco do Sul (Grupo Açungui), durante o Neoproterozoico. A foliação Sn descrita por Siga Junior (1995) e Siga Junior et al. (1995) estaria relacionada à foliação Sn do trabalho atual.

Faleiros et al. (2011) sugeriram a ocorrência de uma deformação multifásica com cavalgamento para oeste, durante o qual as zonas de cisalhamento transcorrentes atuavam como rampas laterais, sobreposto por dobras de vergência na direção norte e por zonas de cisalhamento transcorrentes. A terceira fase poderia estar relacionada à fase Dn da presente pesquisa. Fossen et al. (2019) ratificaram a conclusão de outros autores (Fassbinder, 1996; Ebert \& Hasui, 1998) de que o Cinturão Ribeira constitui parte de um sistema transpressional particionado, formado por zonas de cisalhamento transcorrentes separadas por domínios caracterizados pelo encurtamento ortogonal, enquanto Faleiros et al. (2016) sugeriram a ocorrência de uma deformação multifásica (D1 a D6) relacionadas ao espessamento e exumação crustal.

A deformação das foliações foi estudada e os valores encontrados nos métodos de Fry (Tabela 1), Polar (Tabela 2) e Rf/ $\varphi$ (Tabela 3) são próximos, sugerindo que os marcadores e a matriz acomodaram a mesma intensidade de deformação. Nas rochas mais recristalizadas (amostras 13, 14, 20, 21, 22, 24, 25, 26) o método de Fry é o menos afetado por considerar a distância entre os centros dos cristais. Nos litotipos com textura granoblástica (amostras 1, 2, 3, 4, 5, 6, 7, 8, 9, 10, 11, 12, 15, 16, 17, 18, 19,
23) os métodos Polar e Rf/ $\varphi$ produziram dados mais representativos, considerando que os cristais de quartzo, hornblenda e plagioclásio podem não mostrar grandes diferenças nos valores de strain utilizando os métodos de Fry e Rf/ $\varphi$ (Ring, 1998).

De acordo com todos os métodos de quantificação da deformação estudados a razão de deformação (R) obtida nas amostras para os cristais de quarto variam entre 4,984 a 1,372 no plano XZ e 2,567 a 1,057 no plano YZ. Os valores de $\mathrm{R}$ observados para os feldspatos são 2,959 a 1,081 (plano XZ) e 2,029 a 1,007 (plano YZ). A variação de strain no quartzo é maior do que no feldspato. A diferença no quartzo é de 3,62 no plano XZ e 1,6 no plano YZ, enquanto nos feldspatos é 1,9 no corte XZ e 1,0 no corte YZ, sugerindo que o quartzo acomodou com maior intensidade as tensões regionais, tendo grande importância no controle da reologia crustal.

A análise de deformação pelos três métodos apontou predomínio de elipsoides oblatos, tanto nos diagramas de Flinn quanto nos diagramas de Nadai-Hsü. A coexistência de tectonitos prolatos e oblatos nos diagramas de Flinn poderia implicar em diferentes fases de deformação superimpostas. Os dados relacionados à foliação Sn (pedreiras Artecipe, Atuba, Costa, Inecol e São Jorge, além dos afloramentos em cortes de estrada) e transportados para o modelo de Sanderson \& Marchini (1984), correspondem a uma zona crustal intermediária a inferior.

Passarelli (2001) correlacionou o Bloco Registro com o Complexo Atuba, por apresentarem aspectos litotípicos e geocronológicos similares. O bloco é formado por rochas graníticas com feições migmatíticas, estruturadas na direção NW ou NE, quando influenciado pelo Sistema de Cisalhamento Cubatão-Itariri, denotando a atuação neoproterozoica. A lineação de estiramento mineral mostra caimentos intermediários a baixos para todos os quadrantes, dependendo da região estudada. Os três resultados obtidos pelo método de Fry (Passarelli, 2001) no Bloco Registro apresentam pouca ou nenhuma deformação, posto que o centro do diagrama se mostra como um vazio esférico ou fracamente elíptico. As foliações obtidas nas amostras analisadas pelo método de Fry por aquela autora são semelhantes às direções das foliações Sn-1 e Sn do presente trabalho. O eixo X (N232/44) da amostra K-16 do trabalho de Passsarelli (2001) é semelhante ao 
eixo X da amostra Artecipe 1 (N326/35) e o eixo Z da amostra K-46 (Passsarelli, 2001) é semelhante aos eixos $\mathrm{Z}$ das amostras Artecipe 1 e Atuba 4. Nos dois trabalhos nota-se uma tendência de maior extensão na direção E-W e maior encurtamento no sentido N-S.

\section{CONCLUSÕES}

No município de Curitiba e arredores, o Complexo Atuba mostra elementos planares e lineares dúcteis, que podem ser agrupados em dois tipos distintos: (1) estruturas (Dn-1) com formação de foliação regional (Sn-1) de baixo a alto ângulo de mergulho para SW ou NE, que podem estar rotacionadas para estruturas NESW, com paragêneses de fácies anfibolito superior a granulito, atribuídas ao regime tectônico compressivo (NE-SW); (2) estruturas transcorrentes-transpressivas (Dn) formadas por foliação milonítica (Sn) de direção NE-SW e baixo a alto ângulo de mergulho para SE ou NW, de fácies anfibolito inferior, ao longo da Zona de Cisalhamento Lancinha-Cubatão e Zona de Cisalhamento Curitiba. As principais feições relacionadas ao regime transpressivo (deformação não coaxial e coaxial) foram tectonitos $\mathrm{S}$ ou SL (oblatos) gerados no campo do achatamento aparente; foliações sub-horizontais a verticais, sendo estas paralelas ou subparalelas à Zona de Cisalhamento Lancinha-Cubatão e lineações de estiramento mineral sub-horizontais ou oblíquas. A foliação Sn-1 tem correlação com o Ciclo
Orogênico Transamazônico no Paleoproterozoico e a foliação Sn, que transpõe a primeira, está vinculada aos processos transpressivos do Cinturão Ribeira no Ciclo Brasiliano.

Os indicadores cinemáticos mostraram movimentação sinistral para a foliação Sn. A continuidade lateral das duas foliações miloníticas, além das evidências de recristalização de feldspatos, sugerem que as duas fases de deformação foram controladas por temperaturas superiores a $450^{\circ} \mathrm{C}$. As feições microestruturais dos cristais de quartzo, como subgrãos e contatos irregulares sugerem a participação de mecanismos de migração de borda de grãos.

A razão de deformação obtida pelos métodos de Fry, Polar e Rf/ $\varphi$ não exibe grandes diferenças, o que é característico de deformação por achatamento. Os valores de razão indicaram que o quartzo acomodou as tensões regionais com maior intensidade do que o feldspato. Os elispoides apresentam eixos máximos na direção NE-SW, eixos intermediários para NW e SW e, eixos mínimos orientados principalmente para SE.

\section{AGRADECIMENTOS}

Os autores agradecem à Coordenação de Aperfeiçoamento de Pessoal de Nível Superior (CAPES), à Universidade Federal do Paraná (UFPR), ao Departamento de Geologia da UFPR e ao Laboratório de Análise de Minerais e Rochas (LAMIR), que por meio de seus recursos, facilitaram o desenvolvimento deste trabalho.

\section{REFERÊNCIAS}

ALMEIDA, F.F.M.; HASUI, Y.; BRITO NEVES, B.B.; FUCK, R.A. Brazilian Structural provinces: An Introduction. Earth Sciences Rewiews, v. 17, p. 1-29, 1981.

BASEI, M.A.S.; FRIMMEL, H.E.; NUTTMAN, A.P.; PRECIOZZI, F. West Gondwana amalgamation based on detrital zircon ages from Neoproterozoic Ribeira and Dom Feliciano belts of South America and comparison with coeval sequences from SW Africa. In: PANKHURST, R.J.; TROW, R.A.J.; BRITO NEVES, B.B. de. (eds.), West Gondwana: PreCenozoic Correlations Across the South Atlantic Region. London: Geological Society, Special Publication, v. 294, p. 239-256, 2008.

BASEI, M.A.S.; NUTMAN, A.; SIGA JUNIOR, O.; PASSARELLI, C.R.; DRUKAS, C.O. The evolution and tectonic setting of the Luis Alves microplate of southeastern Brazil: an exotic terrane during the assembly of western Gondwana. Dev. Precambrian Geol. v. 16, p. 273-291, 2009.

BASEI, M.A.S.; SIGA JUNIOR, O.; MACHIAVELLI, A.; MANCINI, F. Evolução tectônica dos terrenos entre os Cinturões Ribeira e Dom Feliciano (PR - SC). Revista Brasileira de Geociências, v. 22, n. 2, p. 216-221, 1992.

CABRITA, D.I.G. Análise da deformação em tectonitos do bloco sul da Zona de Cisalhamento Curitiba (PR). Curitiba,
2015. 92 p. Dissertação (Mestrado em Geociências) Departamento de Geologia, Universidade Federal do Paraná.

CAMPANHA, G.A.C. \& SADOWSKI, G.R. Tectonics of the Southern Portion of the Ribeira Belt (Apiaí Domain). Precambrian Research, v. 98, p. 31-51, 1999.

CAMPANHA, G.A.C.; BASEI, M.S.; FALEIROS, F.M.; NUTMAN, A.P. The Mesoproterozoic to Early Neoproterozoic passive margin Lajeado Group and Apiaí Gabbro, Southeastern Brazil. Geoscience Frontiers, v. 7, n. 4, p. 683-694, 2015.

CAMPANHA, G.A.C. \& BRITO NEVES, B.B. Frontal and oblique tectonics in the Brazilian Shield. Episodes, v. 27, n. 4, p. 255-259, 2004.

CAMPOS NETO, M.C. Orogenic systems from southwestern Gondwana: an approach to Brasiliano-Pan African Cycle and orogenic collage in Southeastern Brazil. In: CORDANI, U.G. (ed.), Tectonic Evolution of South America. Rio de Janeiro: International Geological Congress, SBG, p. 335-365, 2000.

CASTRO, L.G.; FERREIRA, F.J.F.; CURY, L.F.; FIORI, A.P.; SOARES, P.C.; LOPES, A.P.; OLIVEIRA, M.J. Interpretação qualitativa e semiquantitativa dos dados aeromagnéticos sobre a Zona de Cisalhamento Lancinha, porção meridional do Cinturão Ribeira no Estado do Paraná, Sul do Brasil. Geologia USP, Série Científica, v. 14, n. 4, p. 3-18, 2014. 
CHAVEZ-KUS, L. \& SALAMUNI, E. Evidência de tensão N-S intraplaca no neógeno, Complexo Atuba - região de Curitiba (PR). Revista Brasileira de Geociências, v. 38, n. 3, p. 439-454, 2008.

CORREA NETO, A.V.; DAYAN, H.; VALENÇA, J.G.; CABRAL, A.R. Geologia e estrutura da zona de cisalhamento do rio Paraíba do Sul e adjacências, no trecho entre Três Rios (RJ) e Sapucaia (RJ). In: SIMPÓSIO DE GEOLOGIA DO SUDESTE, 3, 1993, Rio de Janeiro. Atas... Rio de Janeiro: SBG, 1993, p. 194-200.

CRESPI, J.M. Some guidelines for the practical application of Fry's method of strain analysis. Journal of Structural Geology, v. 16, p. 1327-1330, 1986.

CUNHA, R.F. Contexto paleoambiental e tafonomia da assembleia fóssil da Formação Guabirotuba, Bacia de Curitiba, Paraná. Curitiba, 2016. 131 p. Dissertação (Mestrado em Geociências) - Departamento de Geologia, Universidade Federal do Paraná.

CURY, L.F. Geologia do Terreno Paranaguá. São Paulo, 2009. 202 p. Tese (Doutorado em Geociências) - Instituto de Geociências, Universidade de São Paulo.

CURY, F.C.; KAULFUSS, G.A.; SIGA JUNIOR, O.; BASEI, M.A.S.; HARARA, O.M.; SATO, K. Idades U-Pb (zircões) de $1.75 \mathrm{Ga}$ em granitoides alcalinos deformados dos núcleos Betara e Tigre: Evidências de regimes extensionais do Estateriano na Faixa Apiaí. Revista do Instituto de Geociências, v. 2, p. 95-108, 2002.

DEHLER, N.M.; MACHADO, R.; FASSBINDER, E. Shear structures in the Serra do Azeite Shear Zone, southeastern Brazil: transtensional deformation during regional transpression in the central Mantiqueira province (Ribeira Belt). J. S. Am. Earth Sci. v. 23, p. 176-192, 2007.

EBERT, H.D. \& HASUI, Y. Transpressional tectonics and strain partitioning during oblique collision between three plates in the Precambrian of southeast Brazil. In: HOLDSWORTH, R.E.; STRACHAN, R.A.; DEWEY, J.F. (eds.), Continental Transpressional and Transtensional Tectonic. London: Geological Society, Special Publications, n. 135, p. 231-252, 1998.

EBERT, H.D.; HASUI, Y.; COSTA, J.B.S. Ocaráter transpressivo do cinturão transcorrente Rio Paraíba do Sul. In: SIMPÓSIO NACIONAL DE ESTUDOS TECTÔNICOS, 3 , 1991, Rio Claro. Boletim de Resumos Expandidos... Rio Claro: SBG., 1991, p. 139-141.

EBERT, H.D.; NEVES, M.A.; HASUI, Y.; SZATMARI, P.; AIRES, R. Evolução dos cinturões de cisalhamento entre os blocos São Paulo, Vitória e Brasília através da tectônica colisional oblíqua: uma modelagem física. In: SIMPÓSIO NACIONAL DE ESTUDOS TECTÔNICOS, 5, 1993, Belo Horizonte. Boletim... Belo Horizonte: SBG, v.12, 1993. p. 254-258.

ELLIOTT, D. Determination of finite strain and initial shape from deformed elliptical objects. Geological Society of America Bulletin, v. 81, p. 2221-2236, 1970.

FALEIROS, F.M. Evolução de terrenos tectono-metamórficos da serrania do Ribeira e Planalto Alto Turvo (SP, PR). São Paulo, 2008. 318 p. Tese (Doutorado em Geociências) Instituto de Geociências, Universidade de São Paulo.

FALEIROS, F.M.; CAMPANHA, G.A.C.; MARTINS, L.; VLACH, S.R.F.; VASCONCELOS, P.M. Ediacaran highpressure collision metamorphism and tectonics of the southern Ribeira Belt (SE Brazil): Evidence for terrane accretion and dispersion during Gondwana assembly. Precambrian Research, v. 189, p. 263-291, 2011.

FALEIROS, F.M.; CAMPANHA, G.A.C.; PAVAN, M.; ALMEIDA, V.V.; RODRIGUES, S.W.O.; ARAUJO, B.P. Short-lived polyphase deformation during crustal thickening and exhumation of a collisional orogen (Ribeira Belt, Brazil). Journal of Structural Geology, v. 93, p. 106-130, 2016.

FASSBINDER, E. Análise estrutural da Falha da Lancinha, Estado do Paraná. São Paulo, 1990. 165 p. Dissertação (Mestrado em Geociências) - Instituto de Geociências, Universidade de São Paulo.
FASSBINDER, E. A unidade Água Clara no contexto do Grupo Açungui: um modelo transpressivo de colisão oblíqua no Neoproterozoico paranaense. São Paulo, 1996. 207 p. Tese (Doutorado em Geociências) - Instituto de Geociências, Universidade de São Paulo.

FIORI, A.P. A Falha da Lancinha no Pré-Cambriano paranaense: reflexo de uma falha profunda? Boletim Paranaense de Geociências, n. 36, p. 6-14, 1985.

FIORI, A.P. Tectônica e Estratigrafia do Grupo Açungui a Norte de Curitiba. São Paulo, 1990. 261 p. Tese (Livre-Docência em Geociências) - Instituto de Geociências, Universidade de São Paulo.

FIORI, A.P. Tectônica e estratigrafia do Grupo Açungui - PR. Bol. IG-USP: Sér. Cient., 23: 55-74, 1992.

FIORI, A.P. Introdução à análise da deformação. Curitiba: Editora da UFPR, 249 p, 1997.

FOSSEN, H. Geologia estrutural. São Paulo: Oficina de Textos, 584 p, 2012

FOSSEN, H.; CAVALCANTE, G.C.G.; PINHEIRO, R.V.L.; ARCHANJOD, C.J. Deformation - Progressive or multiphase? Journal of Structural Geology, v. 125, p. 82-99, 2019.

FRONZA, G.; GILVEIRA, C.T.; FIORI, A.P.; SALAMUNI, E.; NASCIMENTO, E.R.; D'AROZ, P.; MOTTIN, T.E. Aplicativos para geração de estereogramas e classificação de rochas ígneas. In: CONGRESSO BRASILEIRO DE GEOLOGIA, 48, 2016, Porto Alegre. Anais... São Paulo: Sociedade Brasileira de Geologia, 2016. v. 1.

FRY, N. Random point distributions and strain measurement in rocks. Tectonophysics, v. 60, p. 89-105, 1979.

FUCK, R.A.; TREIN, E.; MARINI, O.J. Geologia e petrografia dos migmatitos do Paraná. Boletim Paranaense de Geociências, v. 23-25, p. 5-41, 1967.

GONÇALVES, F.M. Caracterização da Zona de Cisalhamento Curitiba - (PR). Curitiba, 2012. 123 p. Dissertação (Mestrado em Geociências) - Departamento de Geologia, Universidade Federal do Paraná.

HACKSPACHER, P.C.; MORALES, N.; ZANARDO, A.; GODOY, A.M.; OLIVEIRA, M.A.F. de.; ARTUR, A.C. A tectônica transcorrente - transpressiva brasiliana da Folha São Roque - SP. In: CONGRESSO BRASILEIRO DE GEOLOGIA, 37, 1992, São Paulo, Anais... São Paulo: SBG., v. 2, p. 348-350.

HARTMANN, L.A.; SANTOS, J.O.S.; MCNAUGHTON, N.J.; VASCONCELLOS, M.A.Z;; SILVA, L.C. Ion microprobe (SHRIMP) dates complex granulite from Santa Catarina, southern Brazil. An. Acad. Bras. Ciências, v. 72, p. 560-572, 2000.

HASUI, Y. Aspectos geológicos essenciais da secção Caconde Caraguatatuba e suas implicações na reconstituição e evolução do pré-cambriano do Leste Paulista. In: JORNADA CARTA GEOLÓGICA DO ESTADO DE SÃO PAULO EM 1:50.000, 1983, São Paulo, Atas... São Paulo: p. 227-252.

HEILBRON, M.; PEDROSA-SOARES, A.C.; CAMPOS NETO, M.C.; SILVA, L.C.; TROUW, R.A.J.; JANASI, V.A. Província Mantiqueira. In: MANTESSONETO, V. et al., (orgs.), Geologia do Continente Sul-Americano: evolução da obra de Fernando Flávio Marques de Almeida. São Paulo: Ed. Deca, p. 203-234, 2004.

HEILBRON, M.; VALERIANO, C.M.; TASSINARI, C.C.G.; ALMEIDA, J.C.H.; TUPINAMBÁ, M.; SIGA JUNIOR, O.; TROUW, R.A.J. Correlation of Neoproterozoic terranes between the Ribeira Belt, SE Brazil and its African counterpart: comparative tectonic evolution and open questions. In: PANKHURST, R.J.; TROUW, R.A.J.; BRITO NEVES, B.B.; DE WIT, M. (eds.), West Gondwana pre-Cenozoic Correlations across the South Atlantic Region. London: Journal Geological Society London, Special Publication, v. 294, p. 211-232, 2008.

HOSSACK, J.R., Pebble deformation and thrusting in the Bygdin area (Southern Norway). Tectonophysics, v. 5, p. 315-339, 1968.

KUMAR, R.; SRIVASTAVA, D.C.; OJHA, A.K. A comparison of the methods for objective strain estimation from the Fry plots. Journal of Structural Geology, v. 63, p. 76-90, 2014.

LISLE, R.J. Geological Strain Analysis: A Manual for the Rf/ $\varphi$ 
Technique. Oxford: Pergamon Press, 99 p, 1985.

MARSHAK, S. \& MITRA, G. Basic Methods of Structural Geology. New Jersey: Prentice-Hall, 446 p, 1988.

MELO, R.P. \& OLIVEIRA, M.AF. Geologia e litogeoquímica de migmatitos, charnockitos e granulitos do Complexo Guaxupé na região de São João da Boa Vista (SP). Brazilian Journal of Geology, v. 43, n. 2, p. 253-272, 2013.

MULCHRONE, K.F. Fitting the void: Data boundaries, point distributions and strain analysis. Journal of Structural Geology, v. 46, p. 22-33, 2013.

PASSARELLI, C.R. Caracterização estrutural e geocronológica dos domínios tectônicos da porção suloriental do Estado de São Paulo. São Paulo, 2001. 254 p. Tese (Doutorado em Geociências) - Instituto de Geociências, Universidade de São Paulo.

PASSARELLI, C.R.; BASEI, M.A.S.; SIGA JUNIOR, O.; HARARA, O.M.M. The Luís Alvez and Curitiba Terranes: Continental Fragments in the Adamastor Ocean. Regional Geology Reviews - Geology of Southwest Gondwana, 189-216, 2018.

PASSARELLI, C.R.; BASEI, M.A.S.; WEMMER, K.; SIGA JUNIOR, O.; OYHANTÇABAL. P. Major shear zones of southern Brazil and Uruguay: escape tectonics in the eastern border of Rio de la Plata and Paranapanema cratons during the Western Gondwana amalgamation. Int J Earth Sci Geol Rundsch, v. 100, p. 391-414, 2011.

PRAZERES FILHO, H.J. Caracterização geológica e petrogenética do Batólito Granítico Três Córregos (PR-SP): Geoquímica isotópica (Nd-Sr-Pb), idades (IDTIMS/SHRIMP) e $\boldsymbol{\delta}^{\mathbf{1 8}} \mathbf{O}$ em zircão. São Paulo, 2005. 207 p. Tese (Doutorado em Geociências) - Instituto de Geociências, Universidade de São Paulo.

PRAZERES FILHO, H.J.; BASEI, M.A.S.; PASSARELLI, C.R.; HARARA, O.M.M.; SIGA JUNIOR, O. U-Pb zircon ages of post- orogenetic granitic magmatism in Apiaí Folded Belt (Paraná State, southern Brazil): petrological and geotectonic significance. In: IV SOUTH AMERICAN SYMPOSIUM ON ISOTOPE GEOLOGY, 2003. Anais... Salvador: CBPM/IRD, v. 2, p. 656-659.

RAMSAY, J.G. Folding and fracturing of rocks. New York: McGraw-Hill, 568 p, 1967.

RAMSAY, J.G. Shear zone geometry: a review. Journal of Structural Geology, v. 2, p. 83-99, 1980.

RAMSAY, J.G. \& HUBER, M.I. The techniques of modern structural geology: Strain analysis. New York: Academic Press, 278 p, 1983.

RING, U. Volume strain, strain type and flow path in a narrow shear zone. Geol. Rundsch, n. 86, p. 786-801, 1998.

RODRIGUES, S.W.O.; ARCHANJO, C.J.; LAUNEAU, P. Determinação da orientação preferencial de forma (opf) de silicatos em rochas graníticas: Granito Campina Grande (PB). Revista Brasileira de Geociências, v. 39, n. 3, p. 435-451, 2009.

SADOWSKI, G.R. A megafalha de Cubatão no sudeste brasileiro. BoI. IG-USP, Sér. Cient., v. 22, p. 15-28, 1991.

SALAMUNI, E. Tectônica da Bacia Sedimentar de Curitiba (PR). Rio Claro, 1998. 214 p. Tese (Doutorado em Geociências) - Instituto de Geociências e Ciências Exatas, Universidade Estadual Paulista.

SALAMUNI, E.; EBERT, H.D.; BORGES, M.S.; HASUI, Y.; COSTA, J.B.S.; SALAMUNI, R. Tectonics and sedimentation of the Curitiba Basin. Journal of South American Earth Sciences, v. 15, n. 8, p. 901-910, 2003.

SANDERSON, D.J. \& MARCHINI, W.R.D. Transpression. J. Struct. Geol., v. 6, n. 5, p. 449-458, 1984.

SATO, K.; SIGA JUNIOR, O.; NUTMAN, A.P.; BASEI, M.A.S.; MCREATH, I.; KAULFUSS, G. The Atuba Complex, Southern South American Platform: Archean Components and Paleoproterozoic to NeoproterozoicTectonothermal Events. Gondwana Research, v. 6, n. 2, p. 251-263, 2003.
SHAN, Y. An analytical approach for determining strain ellipsoids from measurements on planar surfaces. Journal of Structural Geology, v. 30, p. 539-546, 2008.

SHAN, Y. \& XIAO, W. A statistical examination of the Fry method of strain analysis. Journal of Structural Geology, v. 33, p. 1000-1009, 2011.

SIBSON, R.H. Fault rocks and fault mechanisms. Journal of Geological Society of London, v. 133, p. 191-213, 1977.

SIGA JUNIOR, O. Domínios tectônicos do sudeste do Paraná e nordeste de Santa Catarina: geocronologia e evolução crustal. São Paulo, 1995. 212 p. Tese (Doutorado em Geociências) Instituto de Geociências, Universidade de São Paulo.

SIGA JUNIOR, O.; BASEI, M.A.S.; MACHIAVELLI, A. Evolução geotectônica da porção NE de Santa Catarina e SE do Paraná, com base em interpretações geocronológicas. Revista Brasileira de Geociências, v. 23, n. 3, p. 215-223, 1993.

SIGA JUNIOR, O.; BASEI, M.A.S.; PASSARELLI, C.R.; HARARA, O.M.; SATO, K.; CURY, L.F.; PRAZERES FILHO, H.J. Geocronologia de rochas gnáissico-migmatíticas e sienograníticas do Núcleo Setuva (PR): Implicações Tectônicas. Revista Brasileira de Geociências, v. 37, p. 114-128, 2007.

SIGA JUNIOR, O.; BASEI, M.A.S.; PASSARELLI, C.R.; SATO, K.; CURY, L.F.; MCREATH, I. Lower and Upper Neoproterozoic magmatic records in Itaiacoca Belt (ParanáBrazil): Zircon ages and lithostratigraphy studies. Gondwana Research, v. 15, p. 197-208, 2009.

SIGA JUNIOR, O.; BASEI, M.A.S.; REIS NETO, J.M.; MACHIAVELLI, A.; HARARA, O.M. O Complexo Atuba: um cinturão Paleoproterozoico intensamente retrabalhado no Neoproterozoico. Bol. IG. - USP: Sér. Cient., v. 26, p. 69-98, 1995.

SIGA JUNIOR, O.; BASEI, M.A.S.; SATO, K.; PASSARELLI, C.R.; NUTMAN, A.; MCREATH, I.; PRAZERES FILHO, H. Calymmian (1.50-1.45 Ga) magmatic records in Votuverava and Perau sequences, south-southeastern Brazil: Zircon ages and Nd-Sr isotopic geochemistry. Journal of South American Earth Sciences, v. 32, p. 301-308, 2011.

SILVA, P.C.S.; YAMATO, A.A.; VASCONCELOS, C.S.; LOPES JÚNIOR, I. Projeto Folha de Curitiba (SG-22-X-DI). São Paulo: Relatório Final, 91 p, 1998.

SOARES, A. \& DIAS, R. Constrangimentos dos métodos de Fry e Rf/ $\varphi$ e transecção de dobras: um exemplo de deformação progressiva no Varisco Ibérico. Comunicações Geológicas, v. 101, p. 331-334, 2014.

SOARES, P.C. \& REIS NETO, J. Um estudo de caracterização termodinâmica de microestruturas dos Grupos Açungui e Setuva (PR). In: SIMPÓSIO SUL-BRASILEIRO DE GEOLOGIA, 3, 1987, Curitiba. Anais... Curitiba: SBG., v. 1, p. 147-165.

SORBY, H.C. On the application of quantitative methods to the study of the structure and history of rocks. Journal of the Geological Society of London, v. 64, p. 171-232, 1908.

TWISS, R.J. \& MOORES, E.M. Structural Geology. New York: W.H. Freeman, 532 p, 2007.

VOLLMER, F.W. EllipseFit: Strain and Fabric Analysis Software User Manual Version 3.4.0 [computer software user manual]. Disponível em: http://www.frederickvol lmer.com/ellipsefit/, 2017.

WALDRON, J.W.F.; \& WALLACE, K.D. Objective fitting of ellipses in the centre-to-centre (Fry) method of strain analysis. Journal of Structural Geology, v. 29, p. 1430-1444, 2007.

YAMAJI, A. Theories of strain analysis from shape fabrics: A perspective using hyperbolic geometry. Journal of Structural Geology, v. 30, p. 1451-1465, 2008.

Submetido em 4 de setembro de 2019 Aceito em 30 de abril de 2020 